\title{
Water Supply at Los Alamos 1998-2001
}

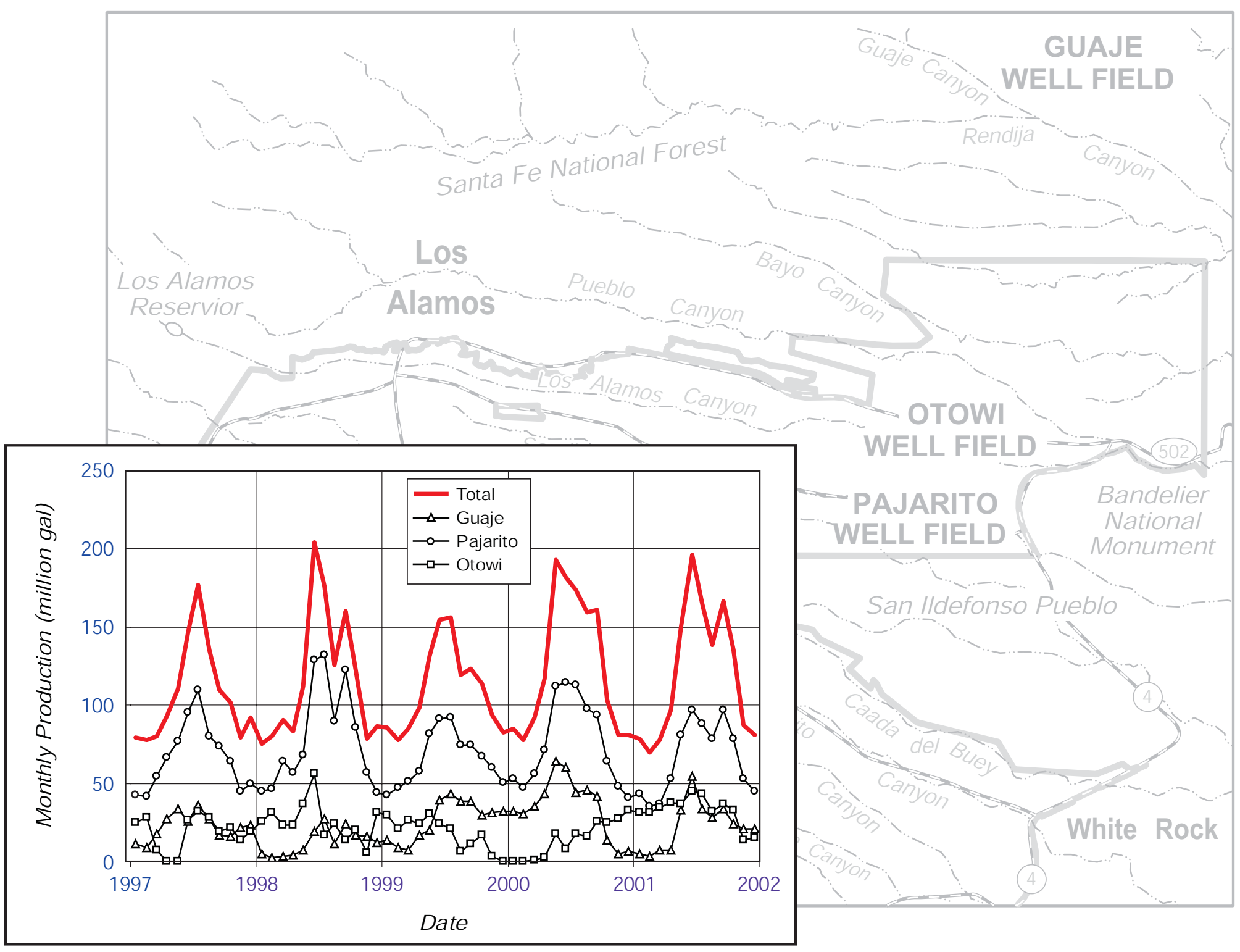




\section{Produced by Risk Reduction and Environmental Stewardship Division}

The chart on the cover shows the monthly groundwater production from each of the well fields at Los Alamos from 1997 through 2001 (Figure 4 of this report). The map (Figure 1 of this report) shows the locations of well fields at Los Alamos.

An Affirmative Action/Equal Opportunity Employer

This report was prepared as an account of work sponsored by an agency of the United States Government. Neither The Regents of the University of California, the United States Government nor any agency thereof, nor any of their employees, makes any warranty, express or implied, or assumes any legal liability or responsibility for the accuracy, completeness, or usefulness of any information, apparatus, product, or process disclosed, or represents that its use would not infringe privately owned rights. Reference herein to any specific commercial product, process, or service by trade name, trademark, manufacturer, or otherwise, does not necessarily constitute or imply its endorsement, recommendation, or favoring by The Regents of the University of California, the United States Government, or any agency thereof. The views and opinions of authors expressed herein do not necessarily state or reflect those of The Regents of the University of California, the United States Government, or any agency thereof. Los Alamos National Laboratory strongly supports academic freedom and a researcher's right to publish; as an institution, however, the Laboratory does not endorse the viewpoint of a publication or guarantee its technical correctness. 
$L A-13985-P R$

Issued: March 2003

Water Supply at Los Alamos, 1998-2001

Richard J. Koch

David B. Rogers 



\section{Table of Contents}

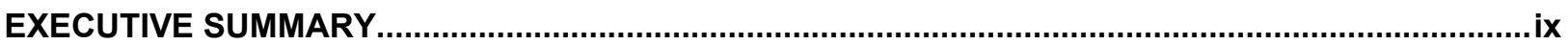

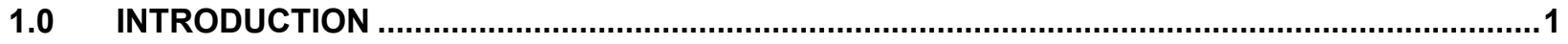

1.1 Transfer of the Water Supply System and Water Rights at Los Alamos ............................. 1

1.2 Guaje Replacement Wells and Abandonment of Old Guaje Wells....................................1

1.3 Brief Description of the Regional Aquifer and the Los Alamos Water Supply System ..........2

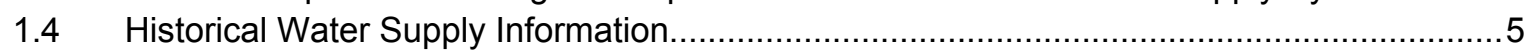

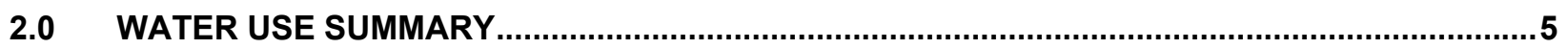

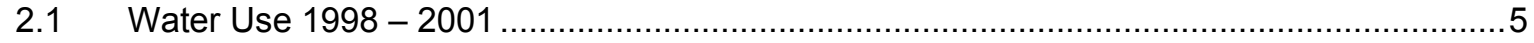

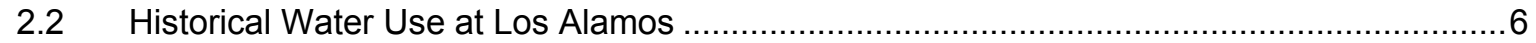

2.3 LANL and Los Alamos County Water Consumption................................................... 7

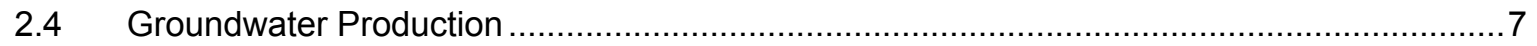

2.4.1 Historical Groundwater Production ..................................................................... 7

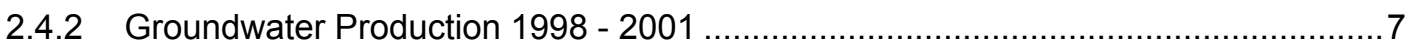

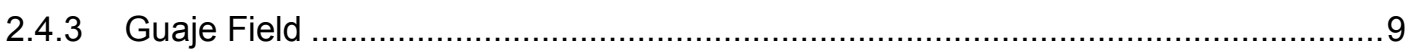

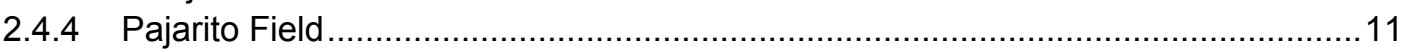

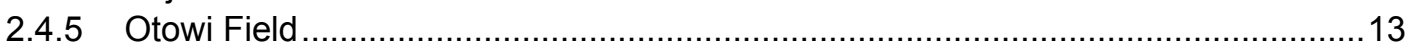

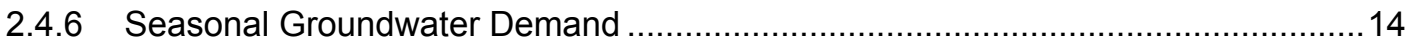

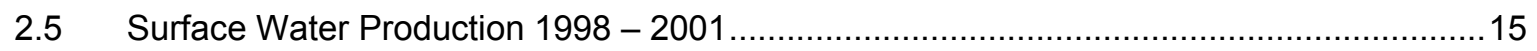

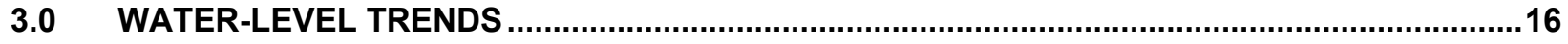

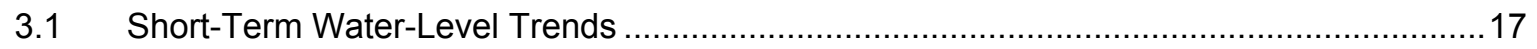

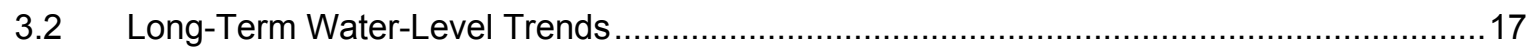

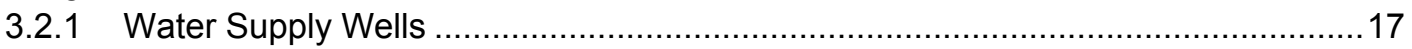

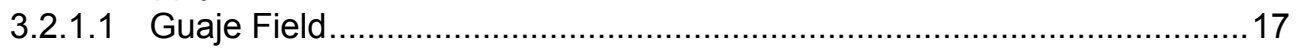

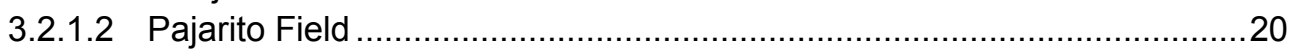

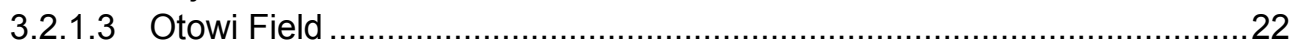

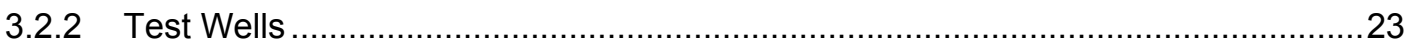

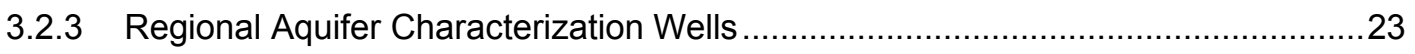

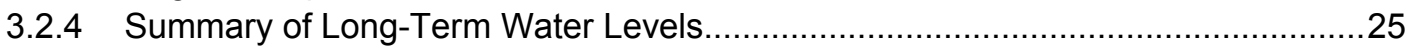

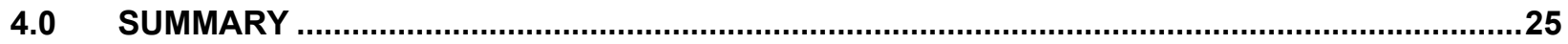

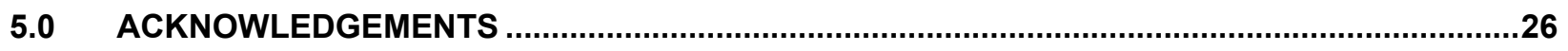

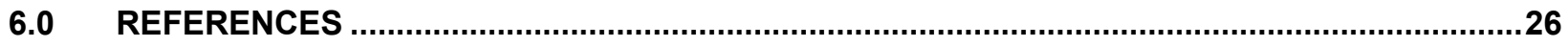

Appendix A. ～List of Water Supply Reports_-1972-1997 ....................................................... A

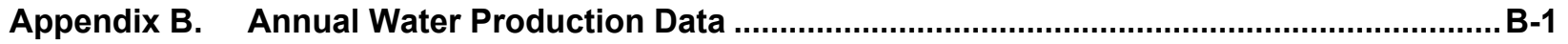

Appendix C. Well Production Data and Aquifer Characteristics .....................................................

Appendix D. Annual Well Data, Aquifer Characteristics, and Water Levels for Active Wells ..... D-1

Appendix E. Short-Term Water-Level Data ................................................................................... E-1

Appendix F. Static Water Levels in Regional Aquifer Test Wells ........................................... F-1 


\section{Figures}

Figure $1 \quad$ Location of water supply wells at Los Alamos.....................................................2

Figure 2 Total water use and surface water use from 1947 to 2001, with annual precipitation at

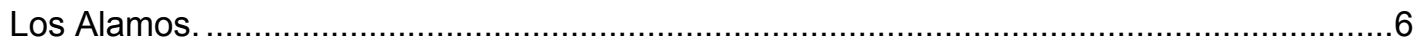

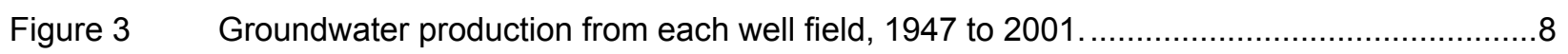

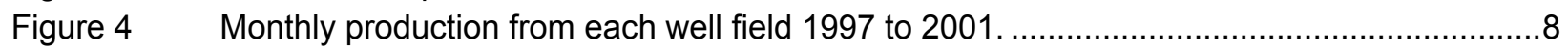

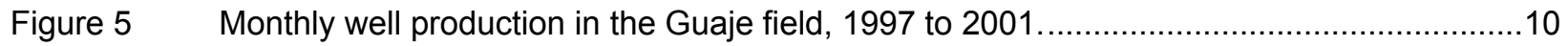

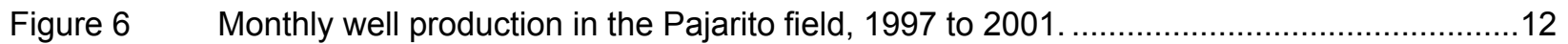

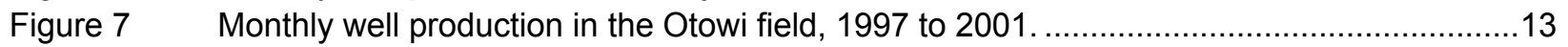

Figure $8 \quad$ Monthly average daily well production at Los Alamos, 1997 to 2001 ..............................14

Figure 9 Average annual nonpumping water elevations of wells in the Guaje field,

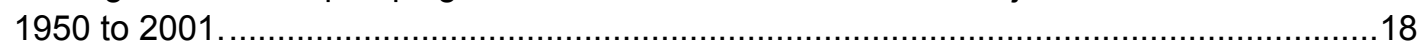

Figure 10 Average annual nonpumping water levels in wells from the Guaje field...........................19

Figure 11 Average annual nonpumping water elevations of wells in the Pajarito field,

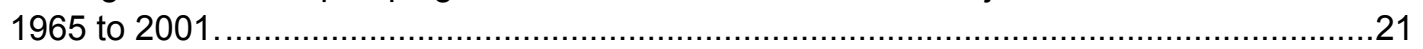

Figure 12 Average annual nonpumping water levels of wells in the Pajarito field...........................22

Figure 13 Average annual nonpumping water levels of wells in the Otowi field,

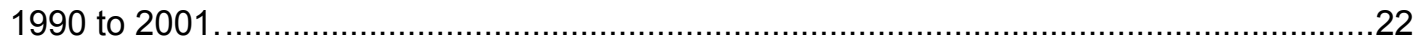

Figure 14 Locations of test wells and regional aquifer characterization wells................................24

Figure E-1 Nonpumping and pumping water levels and monthly production, well G-1A,

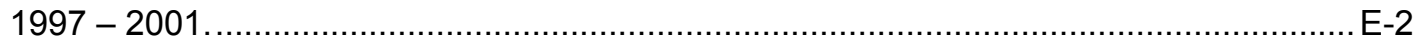

Figure E-2 Nonpumping and pumping water levels and monthly production, well G-2A,

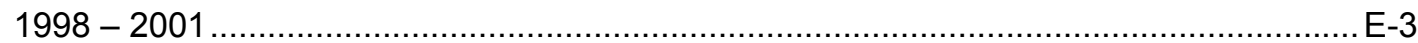

Figure E-3 Nonpumping and pumping water levels and monthly production, well G-3A,

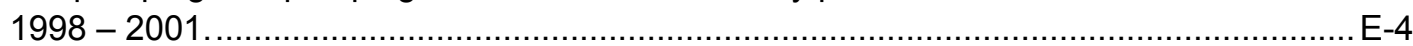

Figure E-4 Nonpumping and pumping water levels and monthly production, well G-4A,

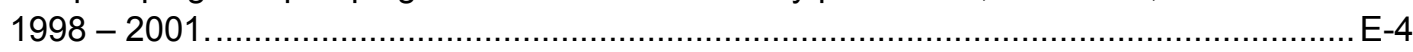

Figure E-5 Nonpumping and pumping water levels and monthly production, well G-5A,

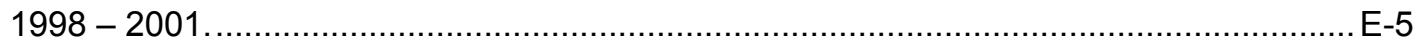

Figure E-6 Nonpumping and pumping water levels and monthly production, well PM-1,

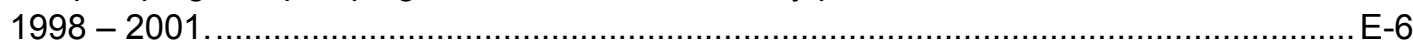

Figure E-7 Nonpumping and pumping water levels and monthly production, well PM-2,

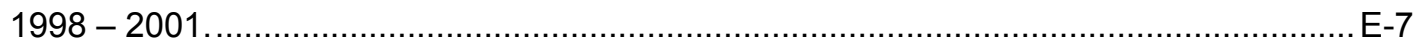

Figure E-8 Nonpumping and pumping water levels and monthly production, well PM-3,

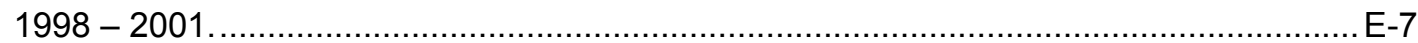

Figure E-9 Nonpumping and pumping water levels and monthly production, well PM-4, $1998-2001$. E-8

Figure E-10 Nonpumping and pumping water levels and monthly production, well PM-5, $1998-2001$. 


\section{Tables}

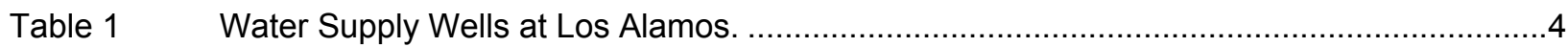

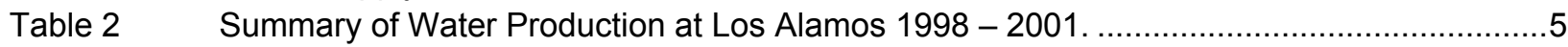

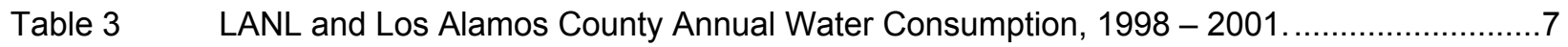

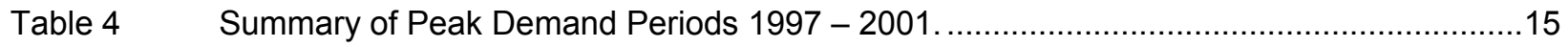

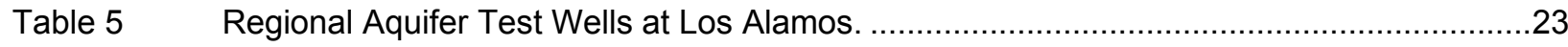

Table $6 \quad$ Regional Aquifer Characterization Wells at Los Alamos..............................................24

Table B-1 Water Production from Well Fields, Springs, and Reservoirs at Los Alamos:

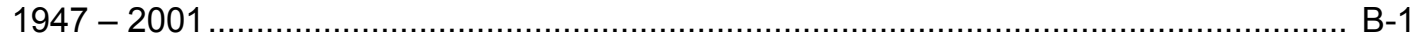

Table C-1 Well Production Characteristics, 1997 through 2001...................................................

Table C-2 Average Pumping Rate, Drawdown, and Specific Capacity, $1997-2001$...................... 1

Table F-1 Depth to Water Measurements in Regional Aquifer Test Wells ...................................... F-1 



\title{
WATER SUPPLY AT LOS ALAMOS, 1998 - 2001
}

\author{
by
}

Richard J. Koch and David B. Rogers

\section{EXECUTIVE SUMMARY}

For the period 1998 through 2001, the total water used at Los Alamos from all sources ranged from 1325 million gallons (Mg) in 1999 to $1515 \mathrm{Mg}$ in 2000. Groundwater production ranged from $1323 \mathrm{Mg}$ in 1999 to $1506 \mathrm{Mg}$ in 2000 from the Guaje, Pajarito, and Otowi fields. Nonpotable surface water used from Los Alamos reservoir ranged from zero gallons in 2001 to $9.3 \mathrm{Mg}$ in 2000. For years 1998 through 2001, over $99 \%$ of all water used at Los Alamos was groundwater.

Water use by Los Alamos National Laboratory (LANL) between 1998 and 2001 ranged from $379 \mathrm{Mg}$ in 2000 to $461 \mathrm{Mg}$ in 1998 . The LANL water use in 2001 was $393 \mathrm{Mg}$ or $27 \%$ of the total water use at Los Alamos. Water use by Los Alamos County ranged from $872 \mathrm{Mg}$ in 1999 to $1137 \mathrm{Mg}$ in 2000, and averaged $1006 \mathrm{Mg} / \mathrm{yr}$.

Four new replacement wells in the Guaje field (G-2A, G-3A, G-4A, and G-5A) were drilled in 1998 and began production in 1999; with existing well G-1A, the Guaje field currently has five producing wells. Five of the old Guaje wells (G-1, G-2, G-4, G-5, and G-6) were plugged and abandoned in 1999, and one well (G-3) was abandoned but remains as an observation well for the Guaje field.

The long-term water level observations in production and observation (test) wells at Los Alamos are consistent with the formation of a cone of depression in response to water production. The water level decline is gradual and at most has been about 0.7 to $2 \mathrm{ft}$ per year for production wells and from 0.4 to $0.9 \mathrm{ft} / \mathrm{yr}$ for observation (test) wells. The largest water level declines have been in the Guaje field where nonpumping water levels were about $91 \mathrm{ft}$ lower in 2001 than in 1951. The initial water levels of the Guaje replacement wells were 32 to $57 \mathrm{ft}$ lower than the initial water levels of adjacent original Guaje wells. When production wells are taken off-line for pump replacement or repair, water levels have returned to within about $25 \mathrm{ft}$ of initial static levels within 6 to 12 months. Thus, the water-level trends suggest no adverse impacts by production on long-term water supply sustainability at Los Alamos. 



\subsection{INTRODUCTION}

This report summarizes production data and aquifer conditions for water production and monitor wells in the Los Alamos, New Mexico, and Los Alamos National Laboratory (LANL) area (Figure 1). Water production wells are grouped within the Guaje, Pajarito, and Otowi fields, the locations of which are shown on Figure 1. Wells from these fields supply all the potable water used for municipal and most industrial purposes in Los Alamos County (LAC), at LANL, and at Bandelier National Monument.

This report has three primary objectives:

(1) Provide a continuing historical record of metered well production and overall water usage;

(2) Provide data to the Department of Energy (DOE) and LANL management, and Los Alamos County planners for operation of the water supply system and for long-range water resource planning; and

(3) Provide water-level data from regional aquifer production wells, test wells, and monitoring wells.

\subsection{Transfer of the Water Supply System and Water Rights at Los Alamos}

In September 1998, the DOE leased the Los Alamos water supply system to LAC and in September 2001 the ownership of the water supply system was officially conveyed to Los Alamos County. The water rights owned by DOE from all permitted sources (surface water and groundwater) in 1998 were 5541.3 acrefeet (ac-ft) per year or about 1805.6 million gallons per year (Mg/yr). In September 1998, these water rights were leased to Los Alamos County. In September $2001,70 \%$ of the water rights (3878.91 ac-ft) were conveyed to Los Alamos County and $30 \%$ of the water rights (1662.39 ac-ft) were leased to Los Alamos County. DOE retained ownership of $30 \%$ of the water rights; this amount of water has been established as a maximum "target quantity" for water use by LANL (Beers et al. 2001). Transfer of ownership of the water supply system and water rights was completed on September 05, 2001.

Prior to September 1998, Johnson Controls Northern New Mexico (JCNNM), the support contractor to LANL and DOE at Los Alamos, maintained and operated the water supply system. At that time, DOE sold water to Los Alamos County for the communities of Los Alamos and White Rock and to the National Park Service for water supply at Bandelier National Monument. After September 8, 1998, the Los Alamos County Utilities Department assumed operation and maintenance of the water supply system, and LANL now purchases water from Los Alamos County. Water meters were installed at all delivery points to LANL, and water now provided to LANL is metered for documentation and billing purposes.

Since 1998, water production records and water-level data for the water supply wells have been collected and maintained by Los Alamos County personnel. These records were provided to personnel of the LANL Water Quality and Hydrology group (RRES-WQH) for compilation into this report. Personnel of the WQH group collect water-level data from test and observation wells. Therefore, this report incorporates contributions of the LANL WQH group and the LAC Utilities Department.

\subsection{Guaje Replacement Wells and Abandonment of Old Guaje Wells}

The original Guaje wells, G-1, G-2, G-3, G-4, and G-5, were constructed in 1950 and 1951. Well G-1A was added in 1954 and well G-6 was added in 1964 to supplement the original Guaje wells. Production from the well field declined during the early 1990 s and the generally deteriorated condition of the original Guaje wells and a desire to improve production efficiency of the field prompted the decision to construct four new replacement wells and permanently abandon six of the seven existing Guaje wells, leaving only original Guaje well G-1A in production. 


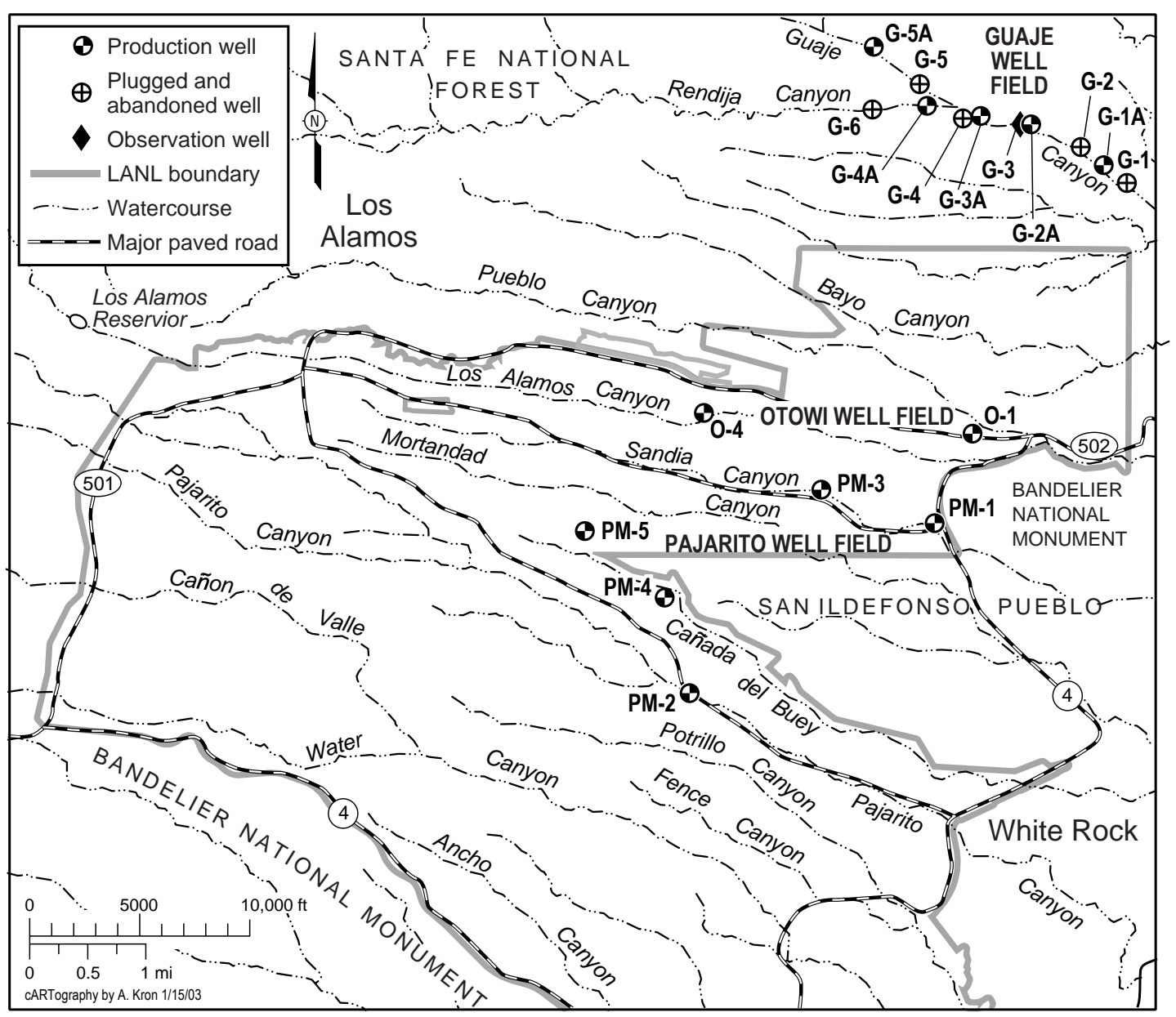

Figure 1. Location of water supply wells at Los Alamos

Four Guaje replacement wells, G-2A, G-3A, G-4A, and G-5A, were constructed between November 1997 and July 1998 but were not fully equipped and ready for service until June through September of 1999 (Shomaker \& Associates 1999; Watson and Rappuhn 1999). When originally drilled, the replacement wells were named GR-1, GR-2, GR-3, and GR-4, but these wells were later renamed G-5A, G-2A, G-3A, and G-4A, respectively. The locations of the replacement wells are shown in Figure 1.

Wells G-1, G-2, G-4, G-5, and G-6 were abandoned and plugged between July and September 1999; well G-3 was abandoned (the pump and associated piping and facilities were removed) but remains as an observation well for the well field (Watson and Rappuhn 1999). Table 1 shows the dates of completion and first production of the replacement wells and the dates of last production from the abandoned wells.

\subsection{Brief Description of the Regional Aquifer and the Los Alamos Water Supply System}

The Guaje, Pajarito, and Otowi fields are located in the mesas and canyons of the Pajarito Plateau (Figure 1). The supply wells are all completed within the regional aquifer, located beneath the Pajarito Plateau, the only local aquifer capable of municipal and industrial water supply in the Los Alamos area. The piezometric surface of the regional aquifer ranges in depth from about $20 \mathrm{ft}$ above ground level (artesian water conditions) in portions of lower Los Alamos Canyon near the confluence with Guaje Canyon, to about $750 \mathrm{ft}$ below ground surface along the eastern edge of LANL property near PM-1, to more than $1230 \mathrm{ft}$ below ground surface near the center of the Pajarito Plateau at well PM-5. Water in the 
regional aquifer generally moves eastward to southeastward beneath the plateau toward the Rio Grande, where at least a portion of the water is discharged into the river through seeps and springs (e.g., Purtymun 1984; Purtymun and Stoker 1988; Purtymun 1995; Nylander et al., 2001). Most of these seeps and springs are located adjacent to the western side of the Rio Grande between Otowi Bridge and Frijoles Canyon above Cochiti reservoir.

Potable groundwater is pumped from the wells into the distribution system. Booster pumps lift the water to terminal storage for distribution to LANL and the community. The entire water supply is disinfected with mixed-oxidant (MIOX) solution before it is distributed to Los Alamos, White Rock, Bandelier National Monument, and LANL areas. The potable water storage tanks at Los Alamos have a combined terminal storage of 35-40 million gallons (Mg). Under drought-like conditions, daily water production alone may not be sufficient to meet water demands, and the county relies upon the terminal storage supply to make up the difference (Beers et al. 2001). The firm rated capacity is the maximum amount of water that can be pumped immediately to meet peak demand. The firm rated capacity of the Los Alamos water production system is 7797 gallons per minute (gpm) or $11.22 \mathrm{Mg}$ per day (Mgpd) (Beers et al. 2001).

The LAC Utilities Department (and before September 1998, JCNNM) maintains a record of the operation of each well along with records of daily and monthly water production using in-line flow meters at each well. Monthly averages of nonpumping and pumping water levels are computed from available daily airline bubble-pressure measurements or pressure transducer data recorded at each well. These data are used to determine individual well pumping rates, drawdown, and other important well field performance information. The annual pumping and production information for all active water supply wells is tabulated in Appendix B. The production characteristics of each well and well field are summarized in Appendix C, and annual production characteristics for each well are tabulated in Appendix D.

Summary information about the wells, including location, depth, surface elevation, date of first (or last, if applicable) production, and initial water depth, is listed in Table 1. All wells are electric except well PM-4. The electric wells are usually operated at night or during the weekend, which are off-peak demand times for electricity. The electric-powered wells pump water as needed to generate an adequate supply for use by LANL and Los Alamos County and for storage. Well PM-4 is powered by a natural gas motor that is typically started in late spring and that operates 24 hours per day during the summer, except for periods when the well is shut down temporarily for maintenance and repairs.

Surface water has historically been collected from reservoirs in Guaje and Los Alamos Canyons, and from the Water Canyon spring gallery (e.g., McLin et al. 1998). However, surface water has not been used from Guaje reservoir since 1991 or from the Water Canyon gallery since 1995. Surface water from Los Alamos reservoir has been used to irrigate public parks and athletic fields in Los Alamos. Water use from Los Alamos reservoir was curtailed in 2000 after the Cerro Grande fire, when floodwaters filled the reservoir with ash and sediment and disabled the water collection system. 


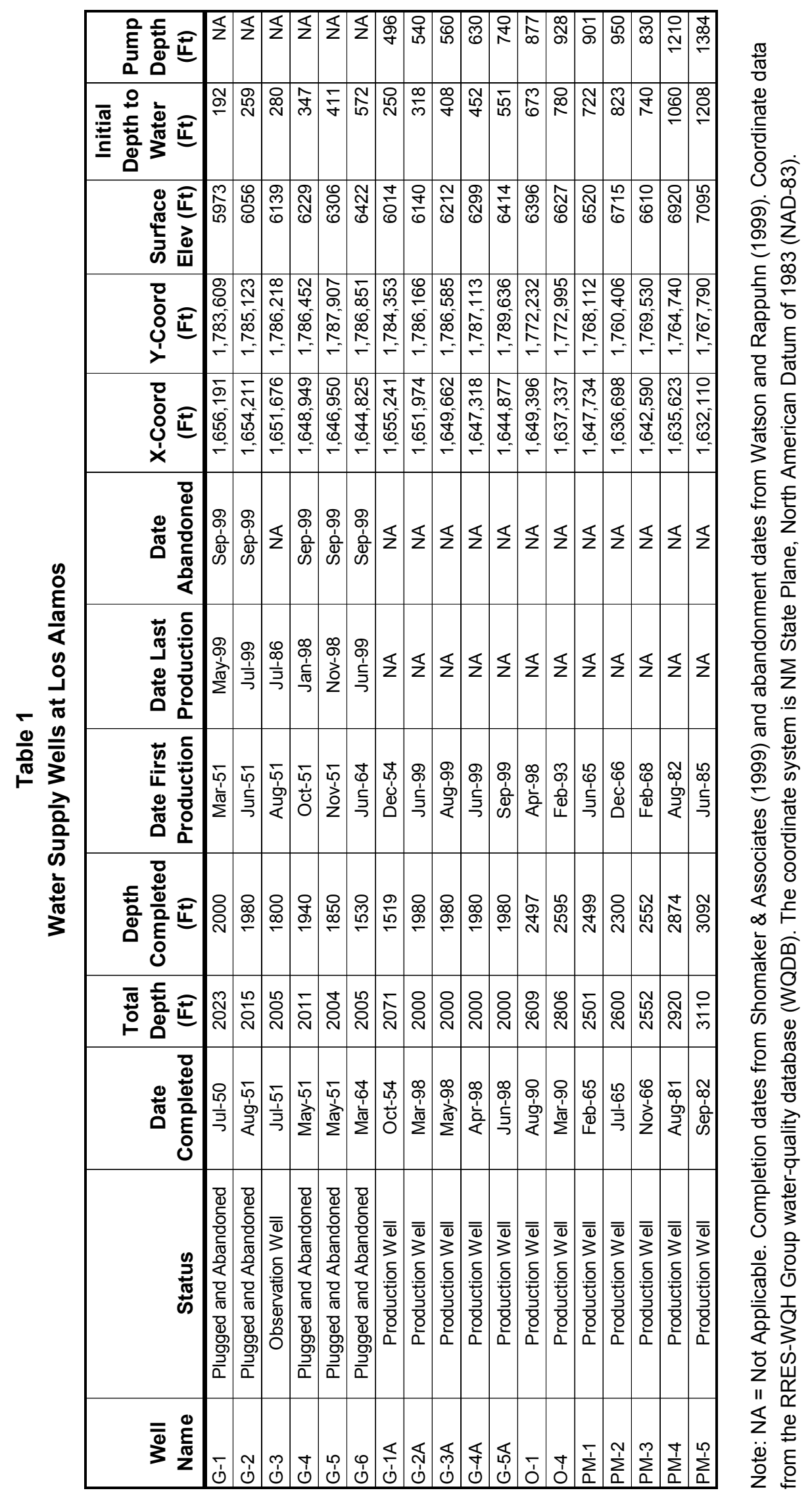




\subsection{Historical Water Supply Information}

A summary hydrologic report for the Pajarito Plateau covered well production for the years from 1947 to 1971 (Purtymun and Herceg 1972). Since then, 27 annual reports containing the results of past water supply studies (these reports are listed in Appendix A) have been published for the years 1972 through 1997. An additional report summarized the hydrology of the regional aquifer and made recommendations for future development of groundwater supplies (Purtymun 1984). A 1988 report examining the status of wells and future water supply (Purtymun and Stoker 1988) and a 1995 report describing individual drilling logs from water supply and test wells (Purtymun 1995) were also published.

Annual historical water production data and aquifer characteristics data for the Los Alamos, Guaje, Pajarito, and Otowi fields are provided in Appendix C. Historical water production and aquifer characteristics data for the former Los Alamos well field was previously reported (McLin et al. 1997a); because production from the Los Alamos well field ceased in 1992, detailed information about this well field is not included in this report. Water-quality data for the regional aquifer are reported in the annual environmental surveillance reports (e.g., ESP 1999, ESP 2000, ESP 2001, ESP 2002). Water-quality data determining compliance of the water supply system with the Safe Drinking Water Act are collected and reported by LAC.

\subsection{WATER USE SUMMARY}

\section{$2.1 \quad$ Water Use $1998-2001$}

For the period 1998 through 2001, the water used each year at Los Alamos is summarized in Table 2. Total water use from all sources (surface water and groundwater) at Los Alamos ranged from $1324.8 \mathrm{Mg}$ in 1999 to $1515.4 \mathrm{Mg}$ in 2000, with an average annual use of $1417 \mathrm{Mg}$.

Groundwater production during this period ranged from $1322.8 \mathrm{Mg}$ in 1999 to $1506.1 \mathrm{Mg}$ in 2000; the average annual groundwater production was $1417.0 \mathrm{Mg}$ (see Section 2.4). The use of nonpotable surface water from Los Alamos reservoir ranged from zero in 2001 to $9.3 \mathrm{Mg}$ in 2000 , which represented $0.6 \%$ of the total water used at Los Alamos (See Section 2.6). For years 1998 through 2001, over $99 \%$ of all water used at Los Alamos was groundwater.

Table 2

Summary of Water Production at Los Alamos 1998-2001

\begin{tabular}{|c|c|c|c|c|c|}
\hline Year & $\begin{array}{c}\text { Potable } \\
\text { Groundwater } \\
\left(\mathbf{1 0}^{6} \text { gal. }\right)\end{array}$ & $\begin{array}{c}\text { Los Alamos } \\
\text { Reservoir } \\
\left(\mathbf{1 0}^{6} \text { gal. }\right)\end{array}$ & $\begin{array}{c}\text { Total Water } \\
\text { Use (106 } \text { gal. })\end{array}$ & $\begin{array}{c}\text { Total Use Change } \\
\text { from Previous } \\
\text { Year (106 } \text { gal. })\end{array}$ & $\begin{array}{c}\text { Total Use as \% of } \\
\text { Water Rights }\end{array}$ \\
\hline 1998 & 1395.9 & 1.6 & 1397.5 & 109.2 & $77 \%$ \\
\hline 1999 & 1322.8 & 2.0 & 1324.8 & -72.6 & $73 \%$ \\
\hline 2000 & 1506.1 & 9.3 & 1515.4 & 190.6 & $83 \%$ \\
\hline 2001 & 1443.4 & 0.0 & 1443.4 & -72.1 & $79 \%$ \\
\hline \multicolumn{7}{|l|}{} \\
\hline Average & 1417.0 & 3.2 & 1420.3 & - & $78 \%$ \\
\hline
\end{tabular}

The total water use at Los Alamos, as a percent of the water rights (5541.3 ac-ft/yr or $1805.6 \mathrm{Mg} / \mathrm{yr}$ ), from 1998 through 2001 is also shown in Table 2. The percent of the water right used ranged from $73 \%$ in 1999 to $83 \%$ in 2000 , with an average of $78 \%$. 


\subsection{Historical Water Use at Los Alamos}

The total annual water use at Los Alamos from all sources (surface water and groundwater) is tabulated in Appendix Table B-1 and is shown in Figure 2. The years of highest annual water use were 1976, when $1736 \mathrm{Mg}$ was used, representing 96\% of the water rights, and in 1989 when $1717 \mathrm{Mg}$ were used, representing $95 \%$ of the water rights. Since 1990, water use at Los Alamos has been less than $1600 \mathrm{Mg}$ per year and use of the water rights has been less than $90 \%$. Also shown in Figure 2 is the amount of surface water used annually. Since 1990, surface water use has been minimal, representing less than $1 \%$ of the total water use; most water used at Los Alamos comes from groundwater (see Section 2.4).

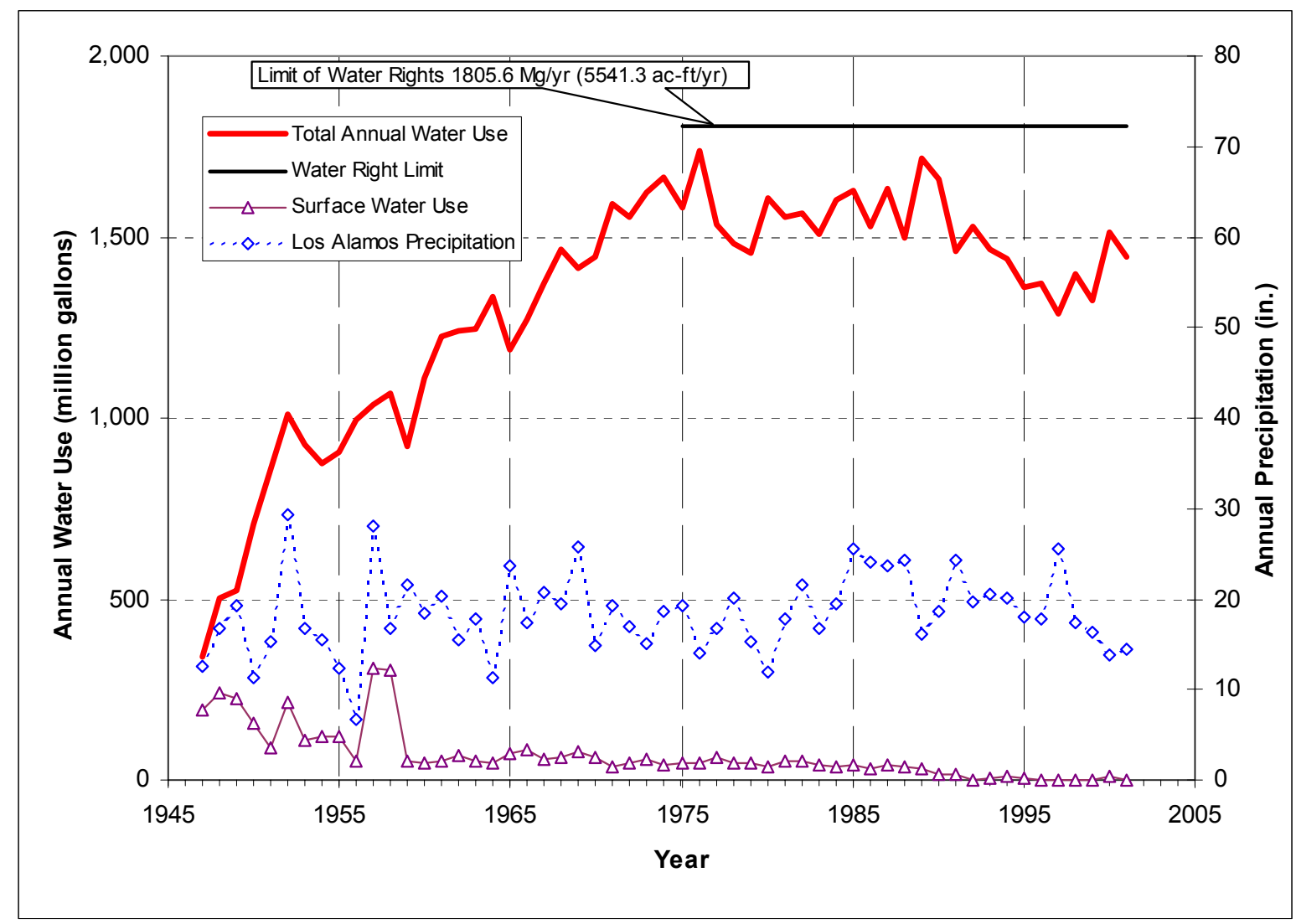

Figure 2. Total water use and surface water use from 1947 to 2001 , with annual precipitation at Los Alamos

Some of the variation in annual water use at Los Alamos results from water use for landscape irrigation, the amount of which is partially governed by annual precipitation. The annual precipitation at Los Alamos (LANL 2002) is shown in Figure 2. In general, since about 1975, the change in annual total water use has generally been inversely related to the annual change in the precipitation at Los Alamos $\left(R^{2}=0.3\right)$; that is, water use tends to be less during wet years and more during dry years (see Figure 2). The historical water-use pattern is shaped by other more critical water-use factors, such as population growth (1947 through 1975) (e.g., Purtymun and Herceg 1976), LANL water conservation measures (1990 through present) (Glasco 2002), etc. 


\subsection{LANL and Los Alamos County Water Consumption}

The annual water use by LANL (calendar year and fiscal year) and by Los Alamos County from 1998 through 2001 is shown in Table 3. Previous water supply reports estimated LANL water consumption to be $30 \%$ of the total water production (McLin et al. 1998). Since the water supply system was transferred to LAC in September 1998, metered records are available to document LANL water consumption for part of 1998 and from 1999 through 2001. LANL water use varied from $379 \mathrm{Mg}$ in 2000 (25\% of total water use) to $461 \mathrm{Mg}(33 \%)$ in 1998. The average LANL water consumption from 1998 through 2001 was approximately $422 \mathrm{Mg}$ per calendar year. All water used by LANL since 1995, when the Water Canyon gallery was last used, is groundwater.

Los Alamos County water use (from all sources) ranged from $872 \mathrm{Mg}$ in 1998 to $1139 \mathrm{Mg}$ in 2000, for an average consumption (1998 through 2001) of 999 Mg per year.

Table 3

LANL and Los Alamos County Annual Water Consumption, 1998-2001

\begin{tabular}{|c|c|c|c|c|}
\hline Year & $\begin{array}{c}\text { Total Annual Water } \\
\text { Use } \\
\text { (Mg/yr) }\end{array}$ & $\begin{array}{c}\text { LANL Water Use } \\
\text { Calendar Year } \\
\text { (Mg/yr) }\end{array}$ & $\begin{array}{c}\text { LANL Water Use } \\
\text { Fiscal Year } \\
\text { (Mg/yr) }\end{array}$ & $\begin{array}{c}\text { Los Alamos County } \\
\text { Water Use } \\
\text { (Mg/yr) }\end{array}$ \\
\hline 1998 & 1397 & 461 & 469 & 936 \\
\hline 1999 & 1325 & 453 & 447 & 872 \\
\hline 2000 & 1515 & 379 & 415 & 1137 \\
\hline 2001 & 1443 & 393 & 371 & 1050 \\
\hline
\end{tabular}

\subsection{Groundwater Production}

\subsubsection{Historical Groundwater Production}

The annual groundwater production from each well field at Los Alamos from 1947 through 2001 is shown in Figure 3 and the data are tabulated in Appendix Table B-1. Since 1968, most groundwater production has come from the Pajarito field. Production from the Otowi field began in 1993, which coincided with a decrease in production from the Guaje field.

\subsubsection{Groundwater Production 1998 - 2001}

The monthly groundwater production from each well field from 1997 through 2001 is shown in Figure 4. The bulk of the groundwater production was from the five wells in the Pajarito field, which produced $54 \%$ of the groundwater in 2001, and up to $68 \%$ of the groundwater in 1998. The Guaje field (5 wells) and the Otowi field ( 2 wells) each contribute about equal amounts of the remaining production. Production from the Guaje field ranged from $11 \%$ of the total in 1998 to $28 \%$ of the total in 2000 , while production from the Otowi field ranged from $11 \%$ of the total in 2000 to $27 \%$ of the total production in 2001 . The production from each field varies each year because of routine cyclical pumping operations and occasional shutdowns for pump maintenance and repair. The production characteristics of each well and field for the period 1997 through 2001 are summarized in Appendix Table C-1. 


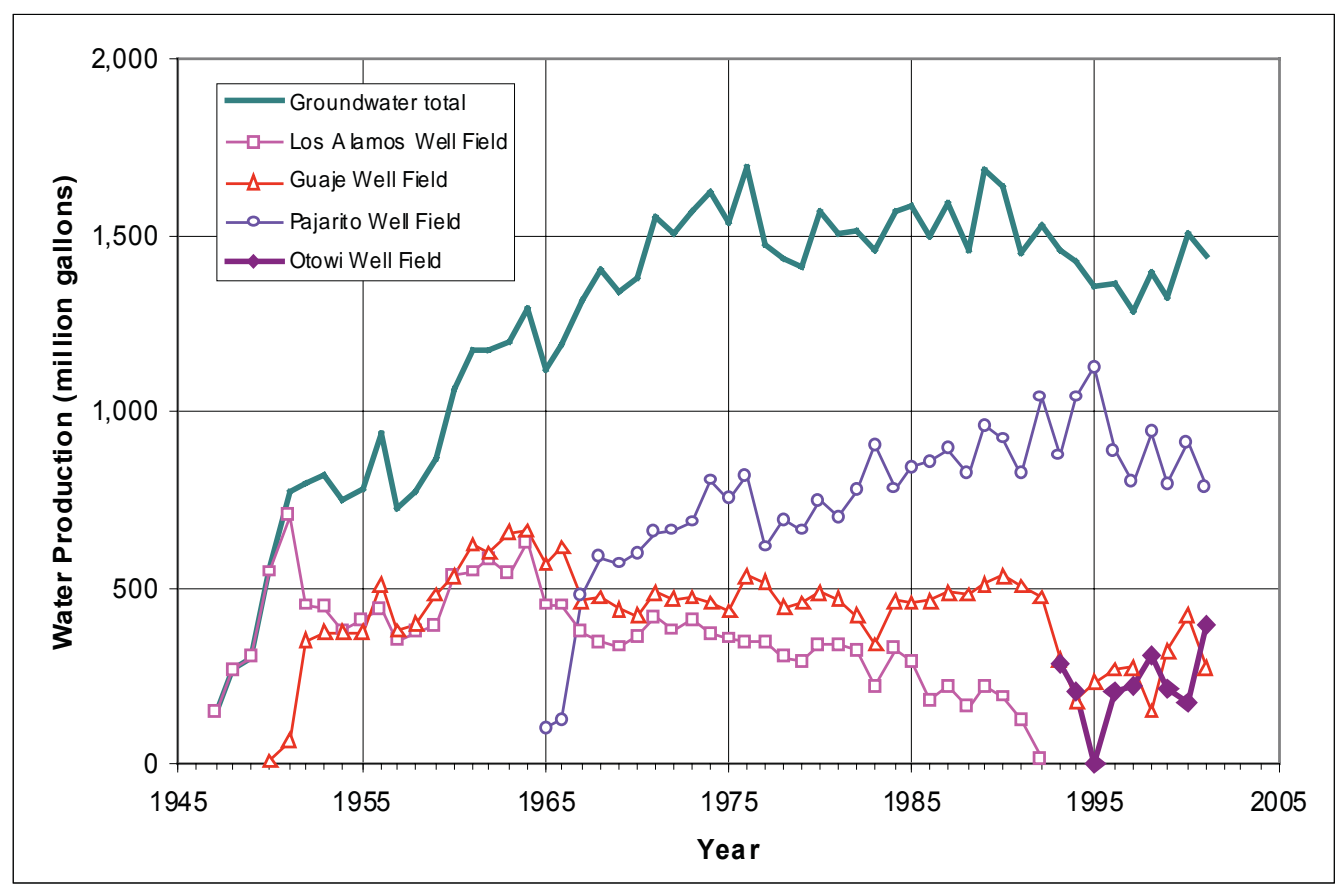

Figure 3. Groundwater production from each well field, 1947 to 2001

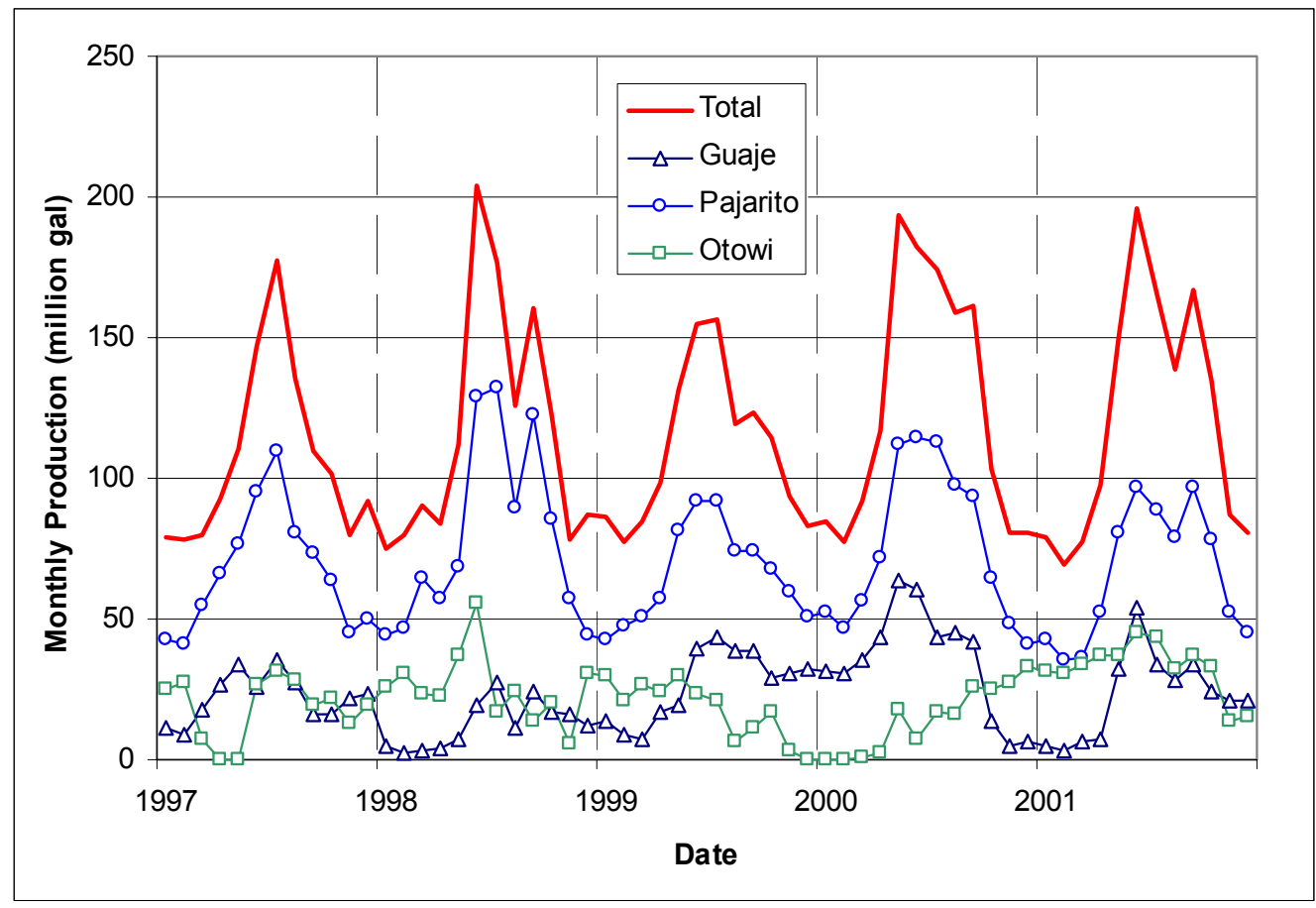

Figure 4. Monthly production from each well field, 1997 to 2001

Average annual pumping rates, drawdown, and specific capacity of production wells are summarized in Appendix Table C-2. Drawdown is the difference between the pumping and nonpumping water levels in each well when the well is operating (see Section 3.1 for detailed information). The average annual drawdown for each well is summarized in Appendix Table C-2 and is tabulated for each well in 
Appendix D. From 1998 through 2001, wells in the Guaje and Pajarito fields had drawdown values ranging from about $25 \mathrm{ft}$ to $80 \mathrm{ft}$, and in the Otowi field (data available for $0-1$ only) drawdown ranged from 100 to $140 \mathrm{ft}$.

The productivity of a well may be expressed in terms of specific capacity. The average specific capacity of each well was calculated by dividing the average annual pumping rate in gpm by the average annual drawdown in feet, to obtain the specific capacity in gpm/ft of drawdown (e.g., Freeze and Cherry 1979). In general, more productive wells have higher specific capacities, and specific capacities of wells tend to decrease over time as a result of factors such as well construction, water chemistry, corrosion, scale build-up, and aquifer properties. In 2000 and 2001, specific capacities of wells at Los Alamos ranged from 3.2 to $26.2 \mathrm{gpm} / \mathrm{ft}$. Wells in the Guaje field averaged $11.3 \mathrm{gpm} / \mathrm{ft}$, and wells in the Pajarito field averaged $22.5 \mathrm{gpm} / \mathrm{ft}$. Tables in Appendix D list the annual production, pump time, pump rate, average pumping and nonpumping water levels, drawdown, and specific capacity for each currently active production well. For the period from 1998 through 2001, no significant changes occurred in the specific capacities of active production wells for which data were available.

\subsubsection{Guaje Field}

The annual production from the Guaje field from 1988 through 2001 ranged from $148.5 \mathrm{Mg}$ in 1998 to $422 \mathrm{Mg}$ in 2000 (Figure 3; Appendix Table B-1). During this period, the Guaje field produced an average of $20 \%$ of the groundwater at Los Alamos. Monthly water production from the Guaje field ranged from 2.6 Mg in February 1998 (during drilling of the replacement wells) to $63.8 \mathrm{Mg}$ in May 2000, at the time of the Cerro Grande fire (Figure 4). Before the replacement wells began production in mid-1999, from January 1997 through June 1999, the Guaje field averaged 17.3 Mg per month. After the replacement wells were placed in service and the original wells were abandoned, from July 1999 through December 2001, the Guaje field averaged $30.1 \mathrm{Mg}$ per month, an increase in production of about $74 \%$. Recent production from the Guaje field, however, has been less than pre-1992 levels (see Figure 3).

The monthly production from each well in the Guaje field is shown in Figure 5. During drilling of the Guaje replacement wells, most production from nearby wells was curtailed; only well G-6, located in lower Rendija Canyon away from most of the replacement well drilling, was consistently pumped during drilling of the replacement wells.

Well G-2A has been the most productive new well in the Guaje field. Under normal operating conditions, this well typically produces 15 to $20 \mathrm{Mg}$ per month and has produced as much as $30.7 \mathrm{Mg}$ in a month. In 2001, well G-2A produced $55 \%$ of the water from the Guaje field and $10 \%$ of the total groundwater produced at Los Alamos (Appendix Table C-1). Wells G-4A and G-5A have been plagued by mechanical problems; these wells were operated intermittently in 2001.

Average pumping rates in the Guaje field in 2001 ranged from $400 \mathrm{gpm}$ at well G-1A to $820 \mathrm{gpm}$ at well G-2A, with a total field pumping rate of $2770 \mathrm{gpm}$ (Appendix Table C-2). Recent drawdown in Guaje wells ranged from $31 \mathrm{ft}$ in well G-1A (1997) to $126 \mathrm{ft}$ in well G-5A (2000). Well G-2A, which produces most of the water from the field, had a maximum drawdown of $56 \mathrm{ft}$ in 2000 . Specific capacity in the Guaje field ranged from $3.2 \mathrm{gpm} / \mathrm{ft}$ at well G-5A in 2000 to $15 \mathrm{gpm} / \mathrm{ft}$ at wells $\mathrm{G}-1 \mathrm{~A}$ and G-2A in 2000 (Appendix Table C-2). 

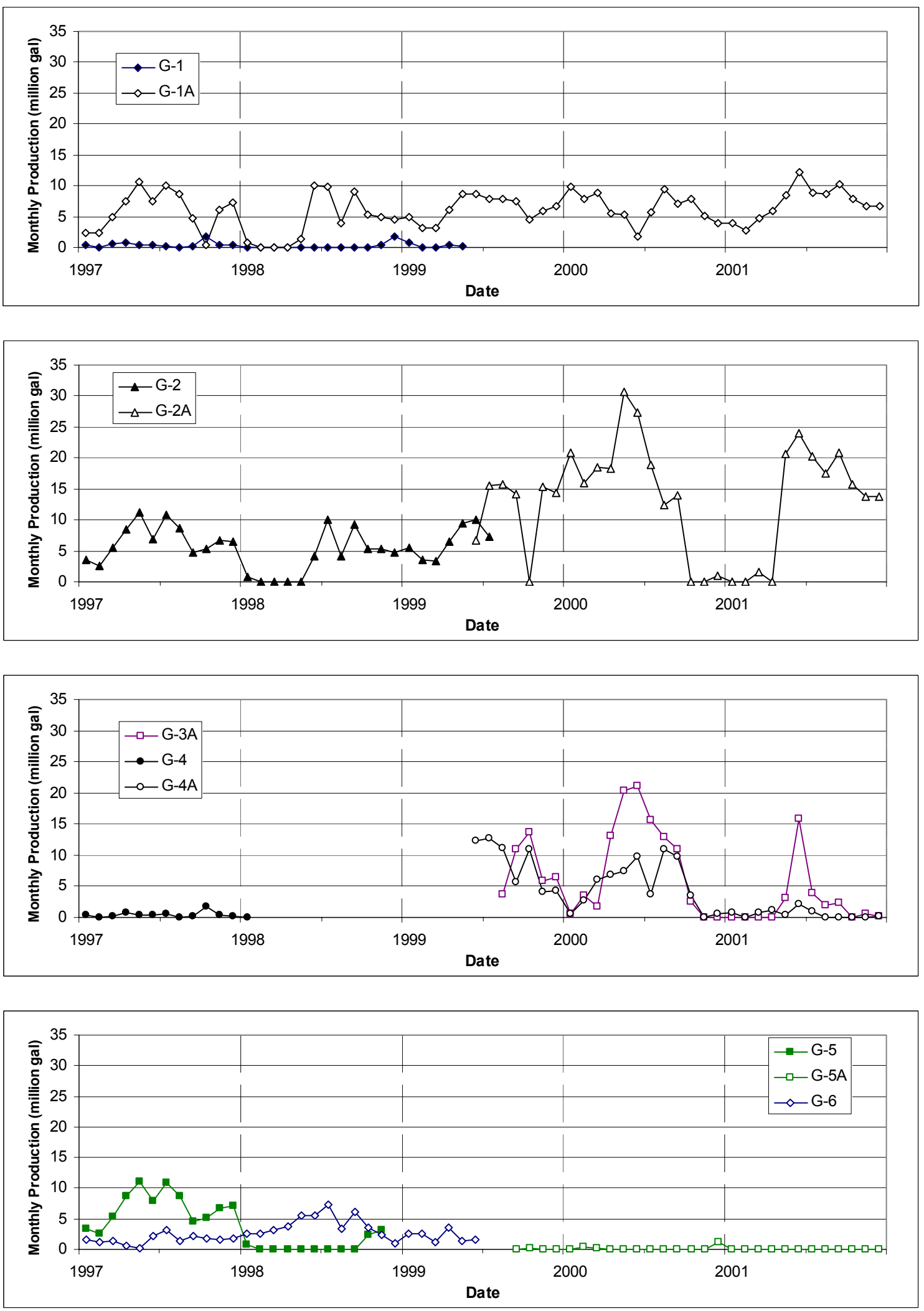

Figure 5. Monthly well production in the Guaje field, 1997 to 2001 


\subsubsection{Pajarito Field}

The Pajarito field consists of five wells that were completed over an 18-year period, from 1965 through 1982; the wells range in depths from 2300 to $3092 \mathrm{ft}$ (Table 1). Wells PM-1 and PM-3 are located in Sandia Canyon, well PM-2 is located in Pajarito Canyon, and wells PM-4 and PM-5 are located on mesas adjacent to Cañada del Buey (Figure 1). The depths to water are substantial, ranging from about $753 \mathrm{ft}$ at $\mathrm{PM}-1$ to more that $1250 \mathrm{ft}$ at PM-5.

From 1998 through 2001, the production from the Pajarito field ranged from $785 \mathrm{Mg}$ in 2001 to $940 \mathrm{Mg}$ in 1998 , for an average annual production of $857 \mathrm{Mg}$ over four years. During this period, the Pajarito field produced an average of $61 \%$ of the water produced at Los Alamos (Appendix Table B-1). Production from the Pajarito field has declined slightly since 1995 but has been supplemented by production from the Otowi field (Figure 3).

The monthly production from each well in the Pajarito field for the years 1997 through 2001 is shown in Figure 6. Because well PM-4 usually operates continuously during the peak summer demand periods, this well typically has the highest monthly production of 50 to $60 \mathrm{Mg}$ when operating. The pump in well PM-4 experienced problems in 1998 and was removed and replaced during the winter and spring of 1999. Well PM-2 typically produces 20 to $40 \mathrm{Mg}$ per month. Wells PM-3 and PM-5 each produce about 10 to $30 \mathrm{Mg}$ per month. Well PM-1 usually produces less than $10 \mathrm{Mg}$ per month.

In 2001, the pumping rates of the Pajarito wells ranged from $586 \mathrm{gpm}$ at PM-1 to $1400 \mathrm{gpm}$ at PM-3 (Table C-2). Four of the wells (PM-2, PM-3, PM-4, and PM-5) are high-yield wells with pumping rates over $1000 \mathrm{gpm}$. The pumping rates from the individual wells varied only slightly from 1997 to 2001 with a total field pumping rate of $5766 \mathrm{gpm}$ in 2001. Specific capacities of wells in the Pajarito field in 1998 ranged from $13.7 \mathrm{gpm} / \mathrm{ft}$ at PM-5 to $52 \mathrm{gpm} / \mathrm{ft}$ at PM-3. Where data are available, no significant changes occurred in the specific capacities of Pajarito field wells from 1998 through 2001. 

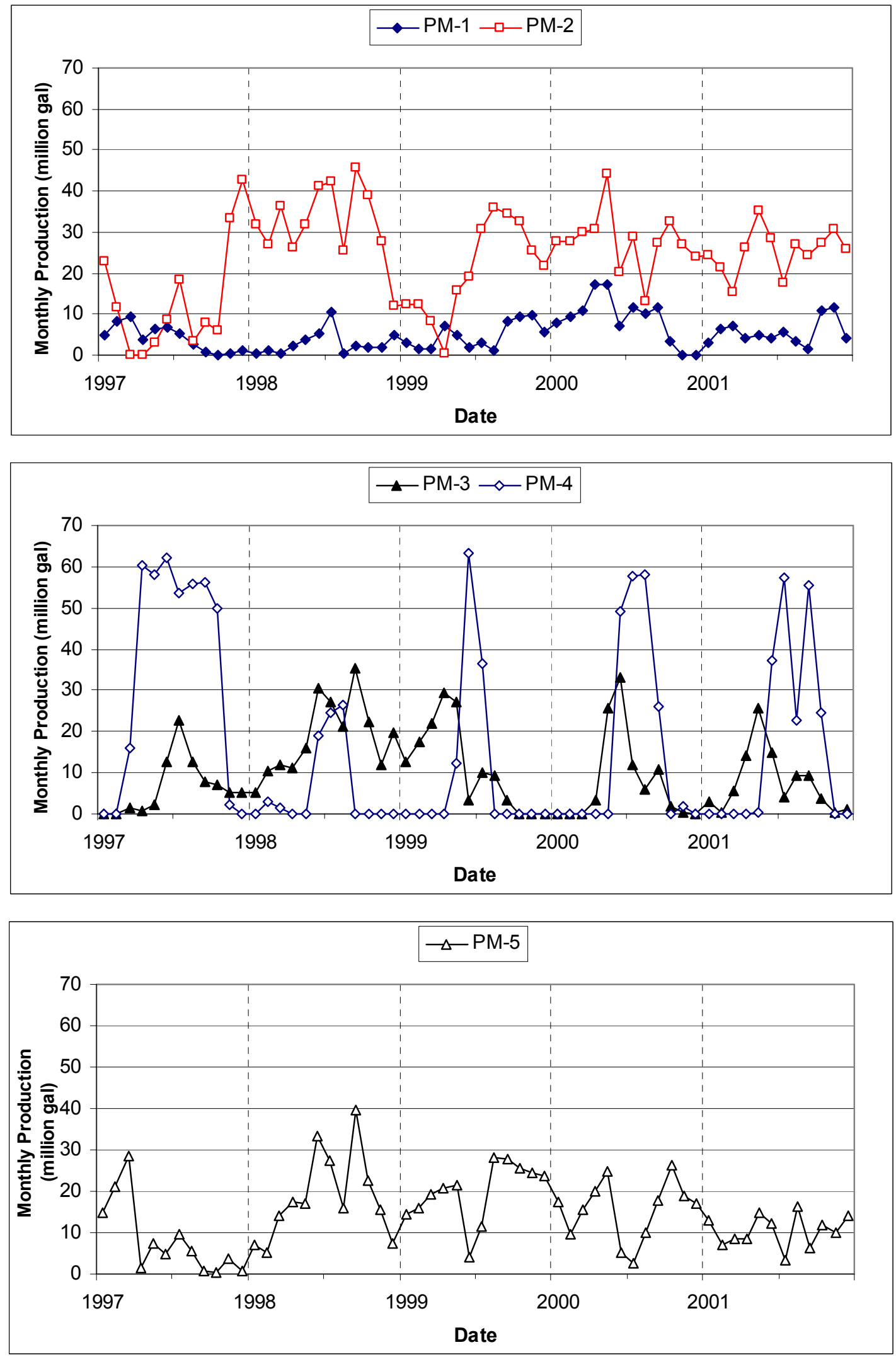

Figure 6. Monthly well production in the Pajarito field, 1997 to 2001 


\subsubsection{Otowi Field}

The Otowi field consists of two wells that were completed in 1990. Well O-1 was completed to a depth of $2497 \mathrm{ft}$; the original depth to the regional aquifer was about $673 \mathrm{ft}$. Well O-4 was completed to a depth of $2595 \mathrm{ft}$, and the original depth to water was about $780 \mathrm{ft}$ (Table 1). Well O-4 began production in February 1993 and well O-1 began production in April 1998.

From 1998 through 2001, the production from the Otowi field ranged from $172 \mathrm{Mg}$ in 2000 to $389 \mathrm{Mg}$ in 2001 , for an average annual production of $270 \mathrm{Mg}$. Most production is from well O-4, which has produced from $69 \%$ to $94 \%$ of the total production from the field. During this period, the Otowi field produced an average of $19 \%$ of the water supply at Los Alamos (Appendix Table C-1). The highest monthly production from the Otowi field was in June 1998 when $55.8 \mathrm{Mg}$ were produced (Figure 4). When operated, the field typically produces about 20 to $40 \mathrm{Mg}$ per month; in 2001, peak monthly production from the field was 45 Mg.

The monthly production from each well in the Otowi field for the years 1997 through 2001 is shown in Figure 7. Well O-4 is a very high-producing well and produces most of the water from the Otowi field. Well O-4 typically produces 25 to $35 \mathrm{Mg}$ per month when operated, and in June 2001 it produced $43.5 \mathrm{Mg}$. In 2001, well O-4 produced $25 \%$ of the total groundwater at Los Alamos (Appendix Table C-2).

Well O-1 produces at a rate of about $973 \mathrm{gpm}$, and well O-4 produces at a rate of about $1450 \mathrm{gpm}$. Water-level data, and therefore drawdown and specific capacity information, are not available for well O-4. The specific capacity of well O-1 declined from $9.7 \mathrm{gpm} / \mathrm{ft}$ in 1999 to $6.9 \mathrm{gpm} / \mathrm{ft}$ in 2001 (Appendix Table C-2).

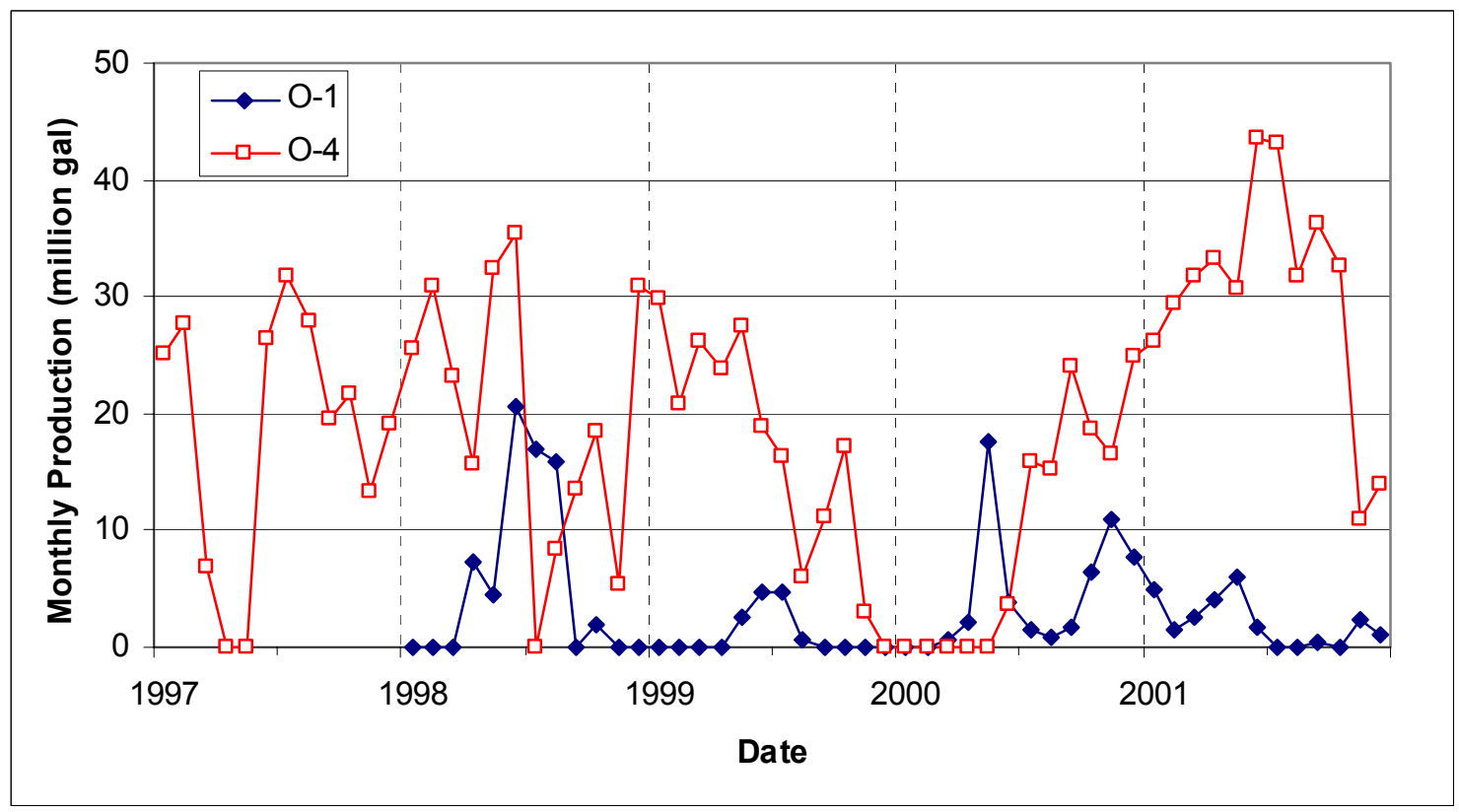

Figure 7. Monthly well production in the Otowi field, 1997 to 2001 


\subsubsection{Seasonal Groundwater Demand}

Peak demand periods generally occur in the summer months between June and September. Low demand periods occur in the winter months from November through February. The monthly average daily well production from 1997 through 2001 is shown in Figure 8. Daily demand during the winter months averages about 2.7 Mgpd. Demand during the summer months is dependent on seasonal weather conditions, and is usually 5 to $7 \mathrm{Mgpd}$. Peak demand periods typically result from landscape irrigation during the dry spring and summer months. Municipal supply wells are operated during peak periods to meet demand and to keep storage tanks filled to capacity for local fire protection.

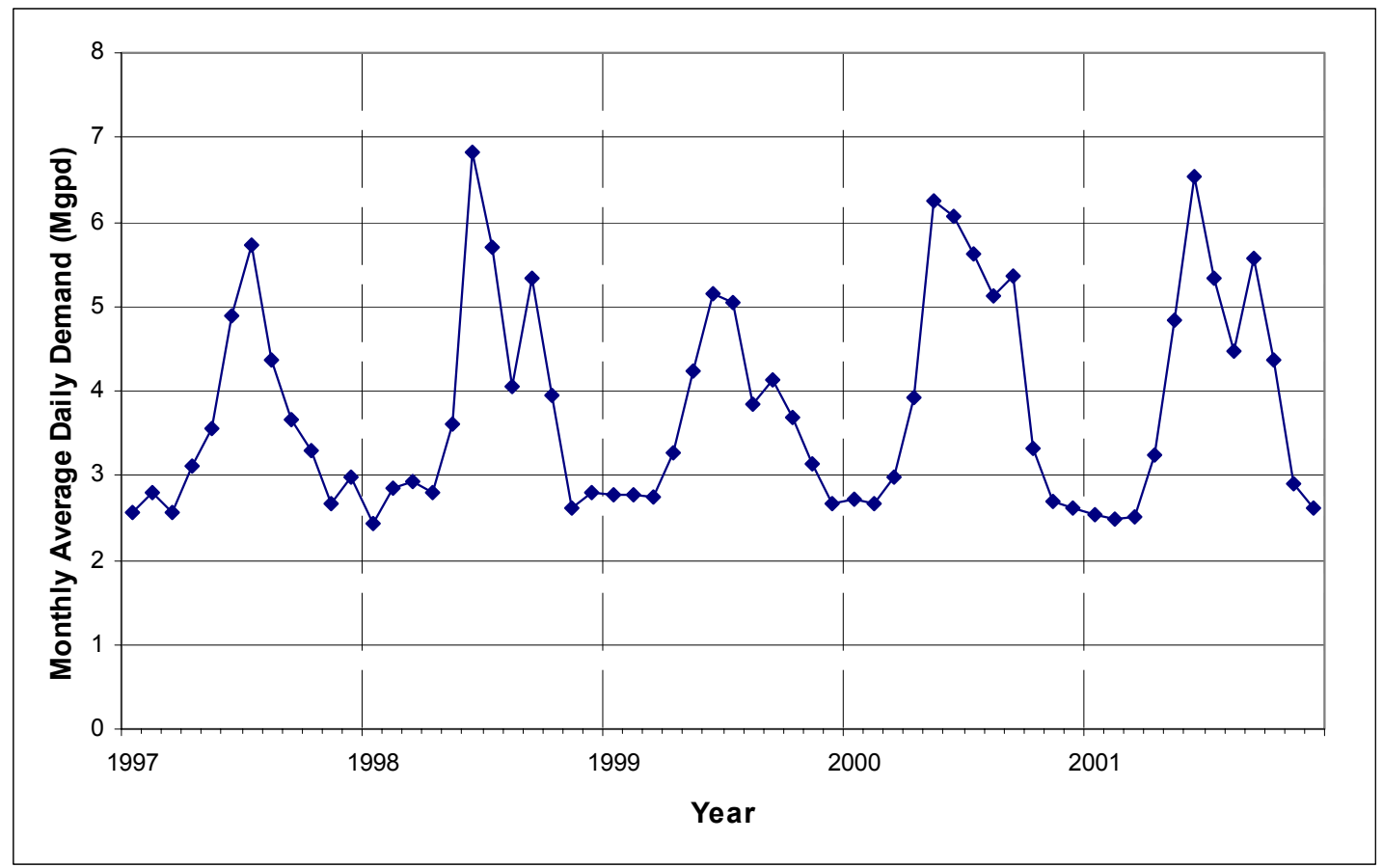

Figure 8. Monthly average daily well production at Los Alamos, 1997 to 2001

Table 4 summarizes the peak demand periods for years 1997 through 2001. Peak demand in 1998 occurred during the month of June when average daily demand was $6.8 \mathrm{Mgpd}$. The average daily demand from June through September in 1998 was 5.5 Mgpd.

In 1999, peak demand occurred in June and July. The highest daily production in 1999 was $9.4 \mathrm{Mg}$ on July 4 , which was $83 \%$ of the firm rated system capacity (see Section 1.3). Production of more than 6 Mgpd occurred on 22 days in 1999, extending intermittently from May 16 to July 30, and from August 29 to September 13. The average daily demand June through September was $4.5 \mathrm{Mgpd}$.

In 2000, peak demand occurred in May, during fighting of the Cerro Grande fire, when $193 \mathrm{Mg}$ were produced during the month. During the fire, $48 \mathrm{Mg}$ were produced from May 8 to May 14, 2000, averaging about 6.8 Mgpd. The peak daily production in 2000 was $10.2 \mathrm{Mg}$ on June 18 , which was $91 \%$ of the firm rated system capacity. Seasonal production of more than $6 \mathrm{Mgpd}$ occurred on 61 days in 2000, extending from April 26 to September 23. The daily use from June through September averaged $5.5 \mathrm{Mgpd}$.

In 2001, peak demand occurred during June when $196 \mathrm{Mg}$ were produced. The peak daily production in 2001 was $8.3 \mathrm{Mg}$ on June 30 , representing $74 \%$ of the firm rated system capacity. Seasonal production of more than 6 Mgpd occurred on 48 days, extending from May 23 to October 17, 2001. The average daily use from June through September was 5.5 Mgpd, similar to year 2000. 
Table 4

Summary of Peak Demand Periods 1997 - 2001

\begin{tabular}{|c|c|c|c|c|c|}
\hline Year & 1997 & 1998 & 1999 & 2000 & 2001 \\
\hline Peak Month & July & June & June & May & June \\
\hline Peak Month Production (Mg) & 177 & 204 & 157 & 193 & 196 \\
\hline Monthly Avg. Daily Prod (Mg) & 5.7 & 6.8 & 5.1 & 6.2 & 6.5 \\
\hline June-Sept Production (Mg) & 569 & 667 & 554 & 676 & 667 \\
\hline Seasonal Avg. Daily Prod (Mg) & 4.7 & 5.5 & 4.5 & 5.5 & 5.5 \\
\hline Date of Peak Production & $7 / 1$ to $7 / 21$ & $7 / 1$ & $7 / 4$ & $6 / 18$ & $6 / 30$ \\
\hline Peak Daily Production (Mg) & 6.7 & 9.5 & 9.4 & 10.2 & 8.3 \\
\hline Peak \% of Rated Capacity & $59 \%$ & $85 \%$ & $83 \%$ & $90 \%$ & $74 \%$ \\
\hline \multicolumn{6}{|l|}{ Number of Production Days } \\
\hline$>10 \mathrm{Mgpd}$ & 0 & 0 & 0 & 1 & 0 \\
\hline$>9 \mathrm{Mgpd}$ & 0 & 2 & 1 & 1 & 0 \\
\hline$>8 \mathrm{Mgpd}$ & 0 & 10 & 3 & 5 & 1 \\
\hline$>7$ Mgpd & 8 & 19 & 9 & 20 & 20 \\
\hline$>6 \mathrm{Mgpd}$ & 13 & 36 & 22 & 61 & 48 \\
\hline
\end{tabular}

\subsection{Surface Water Production 1998 - 2001}

The annual water production from Los Alamos reservoir is tabulated in Appendix Table B-1. Water use from Los Alamos reservoir was 1.6 Mg in 1998, 2.0 Mg in 1999, and 9.3 Mg in 2000. Surface water was used from Los Alamos reservoir until storm runoff after the Cerro Grande fire filled the reservoir with ash, muck, and sediment. The collection system was temporarily disconnected while the reservoir was dredged and the dam structure rebuilt. Storm runoff events in 2001 continued to fill the reservoir with debris resulting from the fire, temporarily preventing water use from the reservoir. Surface water use from Los Alamos reservoir is planned in the future or when conditions at the reservoir permit collecting water of adequate quality.

Water Canyon gallery was a source of potable spring water from the early days of the Manhattan Project until 1987. The use of the gallery as a potable water supply was discontinued in 1987; water from the gallery was used as a nonpotable supply for the steam plant at TA-16 from 1989 until 1995. The collection of water from the Water Canyon gallery ended in 1995 when a tree fell across a raised portion of the collection pipeline, causing significant damage to the pipeline and total loss of collected water to Water Canyon. In 2000, after the Cerro Grande fire, the water collection pipeline was removed from the gallery and from the tributary to upper Water Canyon. Additional information about the Water Canyon gallery was provided in earlier water supply reports (see Appendix A). The historical water production data from the Water Canyon gallery are provided by McLin et al. (1998).

Guaje and Los Alamos reservoirs are man-made reservoirs located on the eastern flanks of the Sierra de los Valles to the northwest and west of Los Alamos. These reservoirs are replenished by snowmelt and storm runoff and by baseflow from spring discharges in upper Guaje and Los Alamos Canyons. During the early days of the Manhattan Project, water from Guaje and Los Alamos reservoirs was used for municipal and industrial supply at Los Alamos. Use of the reservoirs for potable water supply was discontinued in 1958 because of intermittent periods of turbidity caused by summer thunderstorm runoff. Surface water from Guaje reservoir has not been used since 1991 (McLin et al. 1998). 


\subsection{WATER-LEVEL TRENDS}

Water levels have been measured in wells tapping the regional aquifer at Los Alamos since the late 1940s, when the first exploratory wells were drilled by the US Geological Survey (USGS). These data have been documented in various reports over the years and are summarized in Appendices $D$ and $F$. The annual summary data for each water supply well has been documented since 1971 in this series of water supply reports.

The annual water levels for all active water supply wells are tabulated in Appendix $D$, which contains one table for each of the wells used as a water supply well at Los Alamos from 1998 through 2001. The tables include annual average water-level data for both nonpumping and pumping conditions. Table 1 of this report provides information about the location and surface elevation and the water level at the time of completion of each well. Data for the now-abandoned Los Alamos well field were previously reported by McLin et al. (1997a).

Water-level data for supply wells are obtained by LAC personnel using pressure transducers, except for wells G-1A, PM-1 and PM-3, which are equipped with bubble pressure lines. For test wells, water levels are obtained using pressure transducers by WQH personnel. Recent water-level data for test wells are available from the RRES-WQH water-quality database (WQDB) on the Internet at the following website: http://wqdbworld.lanl.gov/. Website data are periodically updated; in addition, the website data can be downloaded in text or spreadsheet format. Historical water-level data for test wells are summarized in Appendix F.

When pressure transducers are installed, water-level measurements are usually obtained manually to calibrate the transducer readings. Occasionally the pressure transducers fail and must be removed or replaced during well maintenance activities. When transducers are replaced, the measurement datum may change by up to 1 to $2 \mathrm{ft}$; as a result, some water-level records might indicate false trends after replacement of transducers.

Most water supply wells at Los Alamos are electric and are operated daily during non-peak electrical demand times. Therefore, most wells are turned on and off each day, which does not allow sufficient time for static pumping or nonpumping water levels to be determined. Well PM-4 is usually operated continuously during summer peak demand periods and is usually not operated during winter months; thus, pumping and nonpumping water levels for this well may at times approach static conditions each year.

The pumping and nonpumping water-level data for the water supply wells were compiled for this report on approximately a weekly basis for each well and the average values for the year were determined (see Appendix C). Water levels in production wells are obtained by two methods: (1) some wells have chart recorders that continuously record water levels above the pump whether they are pumping or not pumping, and (2) some wells have digital readouts in the well house that display the water level above the pump. For wells with digital readouts, LAC employees manually record the water level, usually twice daily during routine inspections of the well equipment, and note whether the pump was operating at the time of recording the water level.

The pumping and nonpumping water levels of wells with chart recorders were determined each week by obtaining the highest water level when the well was not pumping and the lowest water level when the well was pumping. For wells with digital readouts, the daily well inspection and water-level records were reviewed and the highest nonpumping water levels and the lowest pumping water levels were documented for each week. This method attempts to obtain pumping and nonpumping water levels that approach static conditions and eliminates intermediate water levels obtained when the well was on or off 
for short periods of time. The weekly pumping and nonpumping water-level data were compiled for each well and entered into a database for storage and retrieval.

\subsection{Short-Term Water-Level Trends}

The short-term water-level trends of water supply wells typically show the water-level responses to the varying pumping demands placed on each well. The time series plots of pumping and nonpumping shortterm water-level trends of active water supply wells are shown and discussed in Appendix $E$ for each active well. The difference between the nonpumping and pumping water levels is the drawdown.

Prior to September 1998, pumping and nonpumping water-level data were compiled by JCNNM personnel on a monthly basis, and the average monthly drawdown was determined for each well. The monthly water-level and drawdown data were averaged over each year to determine the average annual pumping and nonpumping water levels and drawdown (Appendix D). After the operation of the water supply system was transferred to LAC Utilities Department, personnel began documenting water levels in production wells in January 2000. Therefore, no water-level data are available for production wells from about October 1998 through December 1999. Water-level data recorded by LAC were reviewed for quality and continuity and were compiled on approximately a weekly basis for this report.

The available short-term water-level data show that nonpumping and pumping water levels respond to the pumping stress placed on each well. The figures in Appendix $E$ show the monthly production from each well where water levels were obtained and for nearby wells that appear to indicate water-level impacts. The short-term water-level data indicate that well G-2A may respond to pumping at well G-3A, wells PM-2 and PM-5 appear to respond to high-volume pumping at well PM-4, and well PM-4 appears to respond to pumping at well PM-2. Additional discussion about short-term water-level data is in Appendix E.

\subsection{Long-Term Water-Level Trends}

The average annual nonpumping water levels for each well (Appendix $D$ ) are used to evaluate the longterm water-level trends. The time-series of the average annual nonpumping water levels are plotted in the following charts to provide a graphical view of long-term water-level changes.

\subsubsection{Water Supply Wells}

\subsubsection{Guaje Field}

The annual nonpumping water-level elevations of wells in the Guaje field from 1950 through 2001 are shown in Figure 9, along with the annual water production from the field. The annual average depth to water in Guaje field wells is shown in Figure 10. Water-level data for the original Guaje wells end in 1998 and 1999 when the wells ceased production, and water-level data for the replacement wells begin in 1998 when the replacement wells were drilled. Routine water-level measurements in the new wells began in 1999.

Water levels in the Guaje field declined most during the first 15 years of production in response to field production of 400 to $600 \mathrm{Mg} / \mathrm{yr}$. During the $1970 \mathrm{~s}$ and most of the $1980 \mathrm{~s}$, production was about $450 \mathrm{Mg} / \mathrm{yr}$ and nonpumping water levels in the Guaje field were relatively stable. Slightly higher production of over $500 \mathrm{Mg} / \mathrm{yr}$ from 1989 through 1991 lowered water levels in some wells slightly, but lower production of about $250 \mathrm{Mg} / \mathrm{yr}$ in the mid 1990s allowed water levels to recover slightly (see Figure 9). 


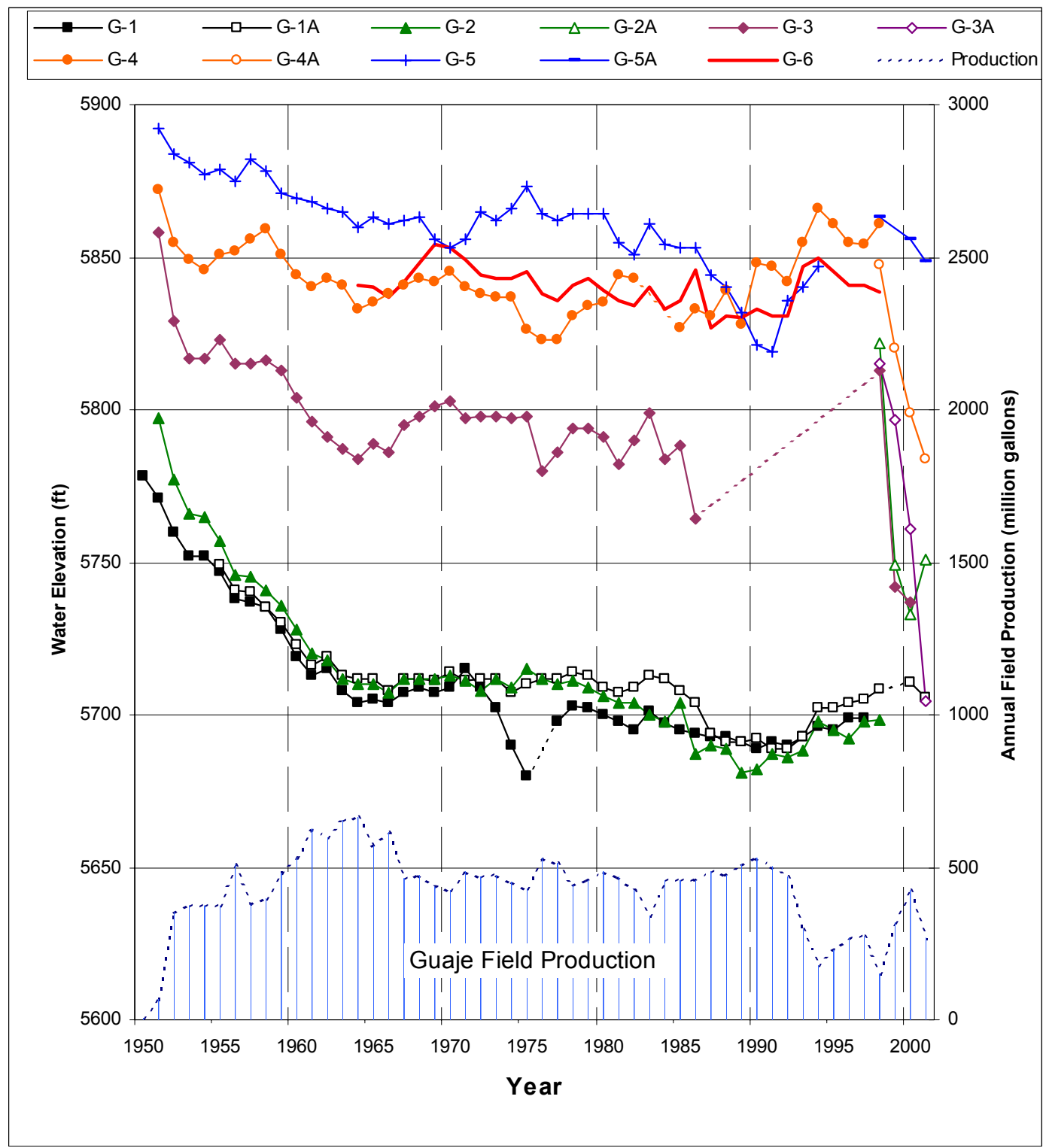

Figure 9. Average annual nonpumping water elevations of wells in the Guaje field, 1950 to 2001

Water levels in wells in the southeast portion of the Guaje field (G-1, G-1A, G-2) have shown the largest decline in water levels (these are also the best producing wells). In 1998, well G-1 had a total decline of about $80 \mathrm{ft}$, and well G-2 had a total decline about $100 \mathrm{ft}$. The nonpumping water levels in well G-1A in 2000 and 2001 were similar to those of the mid 1960s, although annual production from the field was less than in the 1960s.

In 1998, the water elevations of wells G-1, G-1A, and G-2 were each at about $5700 \mathrm{ft}$ (Figure 9). The beginning static water elevations of replacement wells G-2A, G-3A, and G-4A in 1998 were $5821.6 \mathrm{ft}$, $5815.2 \mathrm{ft}$, and $5847.3 \mathrm{ft}$, respectively. However, within a year or two after these replacement wells were placed in service, the nonpumping water levels rapidly lowered to elevations similar to those of the old Guaje wells (5700 to $5750 \mathrm{ft}$ ). 
The largest decline in nonpumping water level from static was at well G-3, which in 2001 had an average nonpumping water level that was $122 \mathrm{ft}$ lower than the original static water level (Figure 10). Replacement well G-3A had an average nonpumping water level in 2001 that was $107 \mathrm{ft}$ lower than the original static water level. In 2001, the average decline was $91 \mathrm{ft}$ in nonpumping water levels from initial water levels for active production wells in the Guaje field (G-1A, G-2A, G-3A, and G-4A).

When well G-3 was converted to an observation well in 1998, the water level showed an average decline of $45 \mathrm{ft}$ from the initial water level in 1951. Observation well G-3 is about $300 \mathrm{ft}$ from replacement well G-2A; consequently, the water levels in well G-3 are influenced by pumping at well G-2A and correspond closely with the nonpumping water levels in well G-2A (Figure 9). In 1998 well G-2A had an initial water level that was $36 \mathrm{ft}$ lower than what was observed initially at well G-3 in 1951, representing an annual decline of about $0.77 \mathrm{ft} / \mathrm{yr}$.

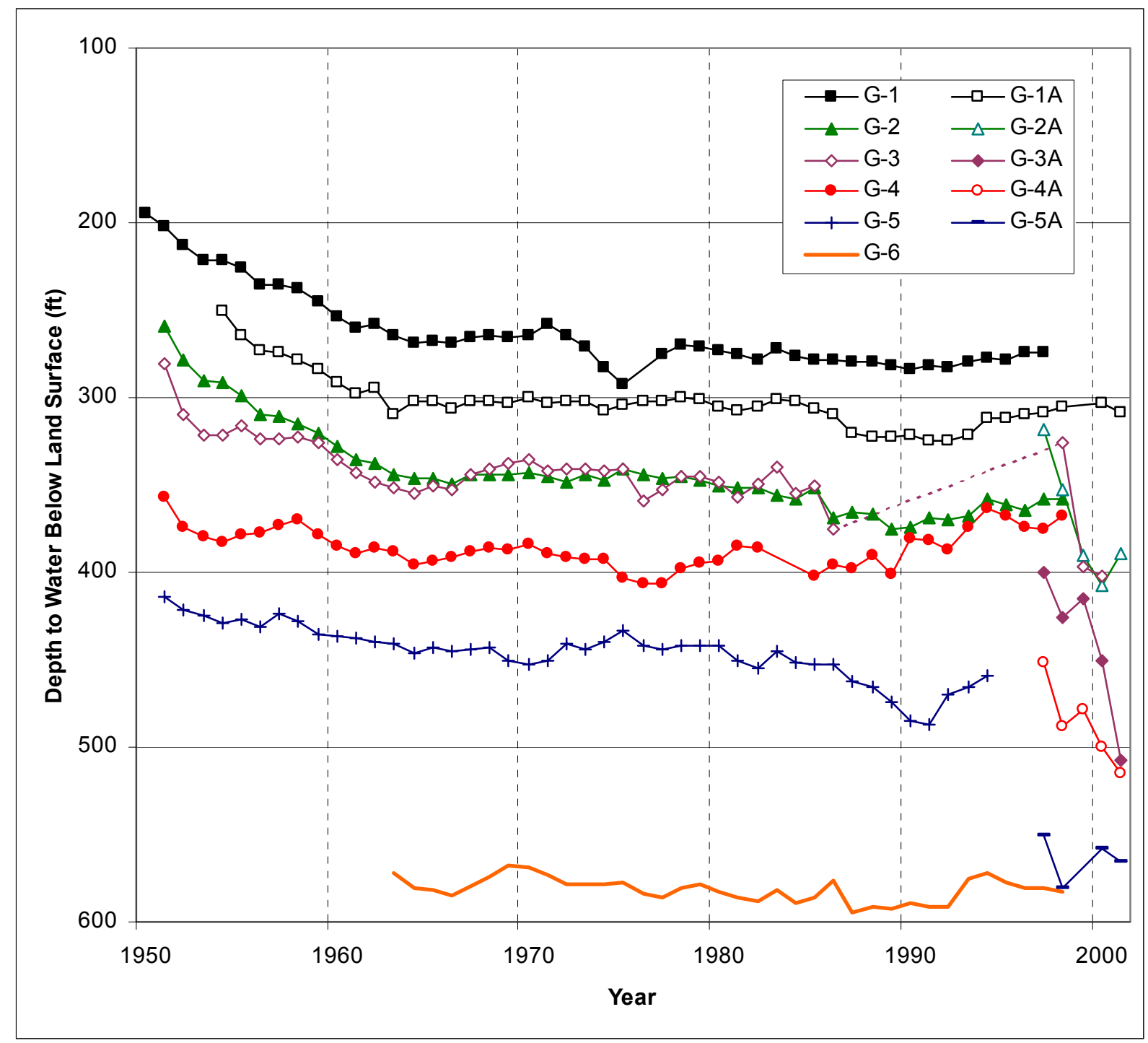

Figure 10. Average annual nonpumping water levels in wells from the Guaje field, 1950 to 2001 
The initial water level in well G-3A was about $57 \mathrm{ft}$ lower in 1998 than what was observed in nearby well G-4 in 1951, representing an annual decline of approximately $1.2 \mathrm{ft} / \mathrm{yr}$. The initial water level in G-4A was about $48 \mathrm{ft}$ lower in 1998 than what was observed in nearby well G-5 in 1951, representing an annual decline of approximately $1.0 \mathrm{ft} / \mathrm{yr}$. The initial water level in well G-5A in 1998 was about $32 \mathrm{ft}$ lower than the initial water level of well G-5 in 1951, representing an annual decline of approximately $0.7 \mathrm{ft} / \mathrm{yr}$.

The long-term water-level observations from the Guaje field are consistent with the formation of a cone of depression in the regional water table in the area of the Guaje field. The cone developed during the initial 15 years of production, from 1950 until about 1964, when wells were added to the field and production from the field was increasing (Figure 9). With the addition of new wells in the Pajarito field in the mid 1960s, annual production levels from the Guaje field were relatively constant (about $500 \mathrm{Mg} / \mathrm{yr}$ ) from 1967 through 1992, and water levels were relatively stable from 1967 through 1979. This period of stable water levels indicates that the cone of depression may have approached equilibrium with respect to the volume of withdrawals. Water levels in the Guaje field show a gradual decline from 1980 to 1990, suggesting an enlargement of the cone of depression in response to a possible external stimulus such as increased production from the Pajarito field (see Figure 3). Water levels in the Guaje field show a slight rise from 1990 to 1998 , probably in response to the significantly reduced production from the Guaje field during this period (Figure 3).

During drilling of the Guaje replacement wells in 1998, nearby wells were not in full production for several months. The initial static water levels in the replacement wells were 32 to $57 \mathrm{ft}$ lower than adjacent original Guaje wells, but after the wells were placed in service, water levels quickly lowered an average of $64 \mathrm{ft}$ (the range is from 15 to $107 \mathrm{ft}$ ) by 2001 (Figure 10). Well G-1 was not routinely in service for about four months during early 1998 when the replacement wells were drilled. The nonpumping water levels in this well recovered about $10 \mathrm{ft}$ during this period, not significantly different from when the well was not in routine service during winter months (see Appendix E).

The historical withdrawal rates and water-level data show that the water levels are relatively stable and resilient, readily responding to changes in withdrawal rates. Water levels naturally respond to changes in withdrawal rates from the Guaje field, and possibly to changes in withdrawals from other nearby well fields, although to a lesser degree. The long-term water-level trends in the Guaje field indicate that current groundwater withdrawals are not negatively impacting the aquifer.

\subsubsection{Pajarito Field}

The average annual nonpumping water elevations of wells in the Pajarito field are shown in Figure 11, and the average annual depth to water is shown in Figure 12. Wells PM-1 and PM-3 exhibit a gradual but steady decline through the years. In 1997, the total decline at PM-1 was $14 \mathrm{ft}$, representing an average annual decline of about $0.4 \mathrm{ft} / \mathrm{yr}$. The total decline at well PM-3 was $37.5 \mathrm{ft}$ in 1998, representing an average annual decline of about $1.25 \mathrm{ft} / \mathrm{yr}$.

The water-level trends of wells PM-2, PM-4, and PM-5 are more varied from year to year, primarily in response to changes in annual withdrawals. In 1983, the maximum decline in well PM-2 was about $50 \mathrm{ft}$, representing an average annual decline of about $2.8 \mathrm{ft} / \mathrm{yr}$. In 2001, the total decline at well PM-2 was about $32 \mathrm{ft}$ from the initial static water level. Well PM-4 had a maximum decline of $33 \mathrm{ft}$ in 1997, which represented an average annual decline of about $2.1 \mathrm{ft} / \mathrm{yr}$. A reduced amount of annual production (at least $50 \%$ ) from well PM-4 since 1997 (Appendix D) has resulted in a recovery of the nonpumping level; in 2001, the change from initial static water level was about $19 \mathrm{ft}$. The maximum decline at well PM-5 was $50 \mathrm{ft}$ in 1996, but reduced production since then has allowed the water level to recover to $31 \mathrm{ft}$ in year 2000 , representing a total annual decline of about $1.7 \mathrm{ft} / \mathrm{yr}$. In 1998 (the last year data were available for 
each Pajarito well), the average decline from initial water levels of nonpumping water levels for all wells in the Pajarito field was about $34 \mathrm{ft}$.

The Otowi field began production in 1993 when slightly lower water levels were observed at well PM-1 and possibly at PM-3 (Figure 11). Water levels rose slightly at PM-1 in 1994 and 1995, apparently in response to less production from the Otowi field in 1994 and no production in 1995. The available waterlevel data from wells PM-1 and PM-3 indicate that these wells appear to respond to production from the Otowi field.

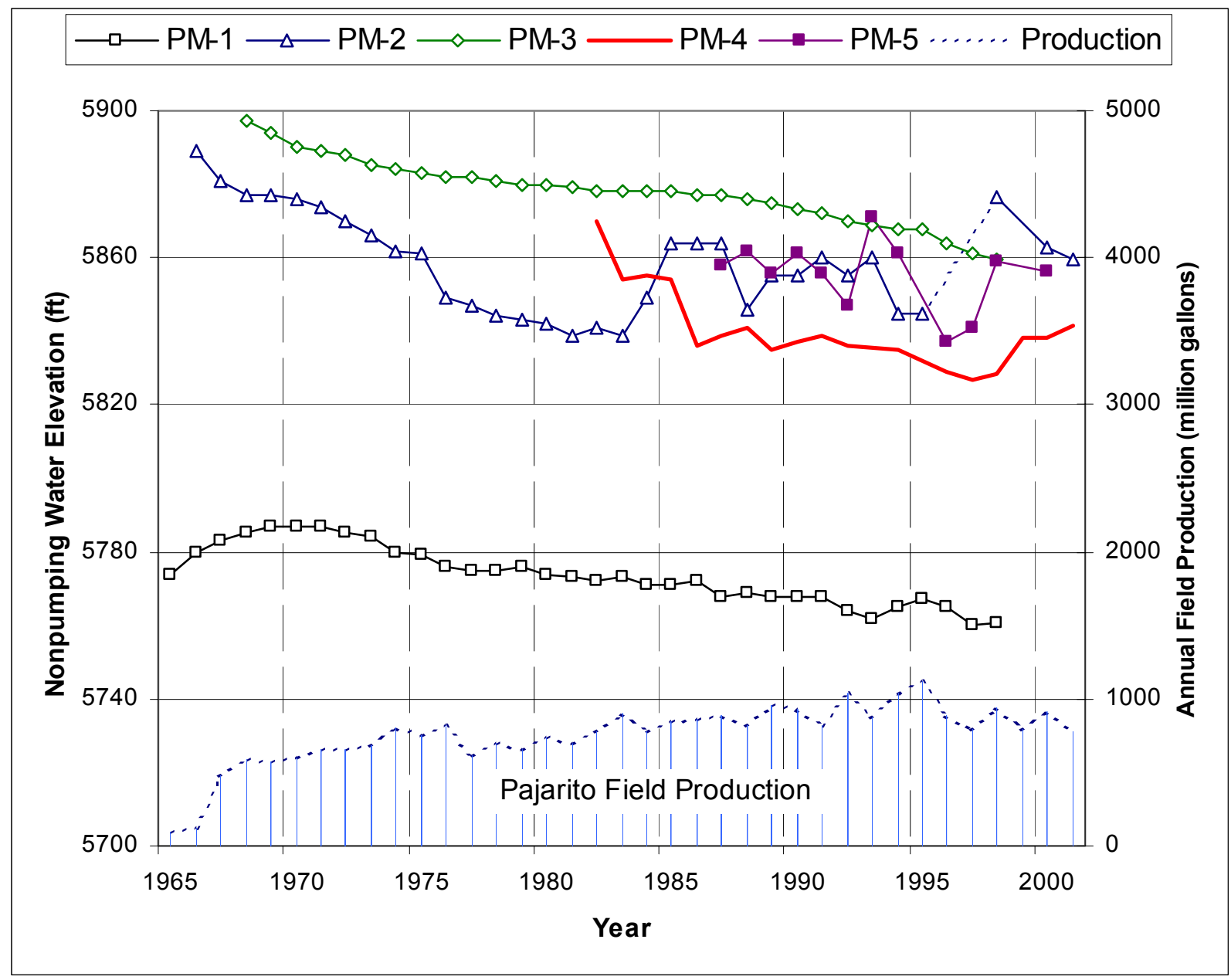

Figure 11. Average annual nonpumping water elevations of wells in the Pajarito field, 1965 to 2001 


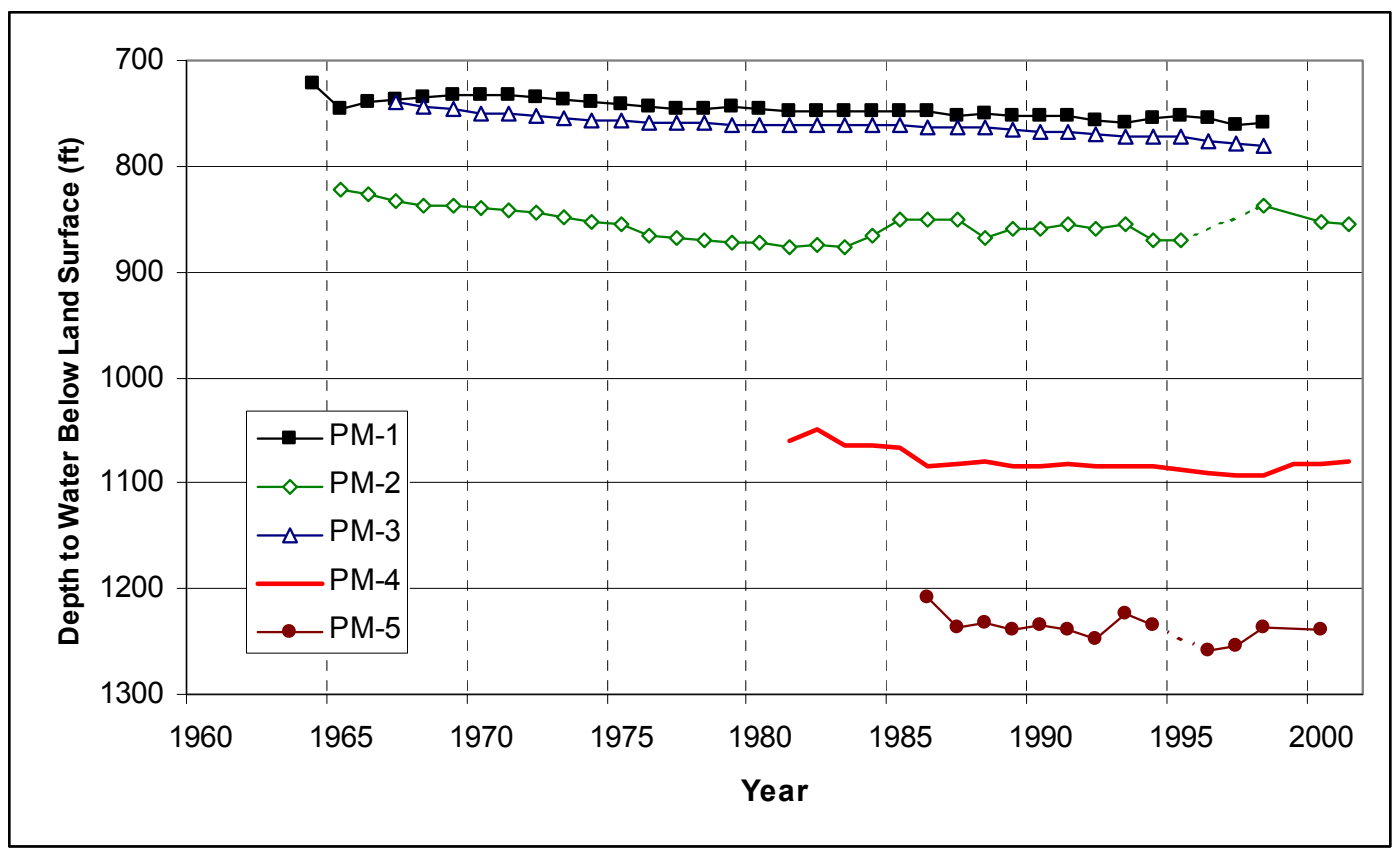

Figure 12. Average annual nonpumping water levels of wells in the Pajarito field, 1964 to 2001

\subsubsection{Otowi Field}

The average annual nonpumping water levels of wells in the Otowi field are shown in Figure 13, along with the annual production from the field. Water-level data have not been available for well $0-4$, although most of the production is from this well. Sporadic production from well 0-1 caused a maximum decline of about $27 \mathrm{ft}$ in 1999.

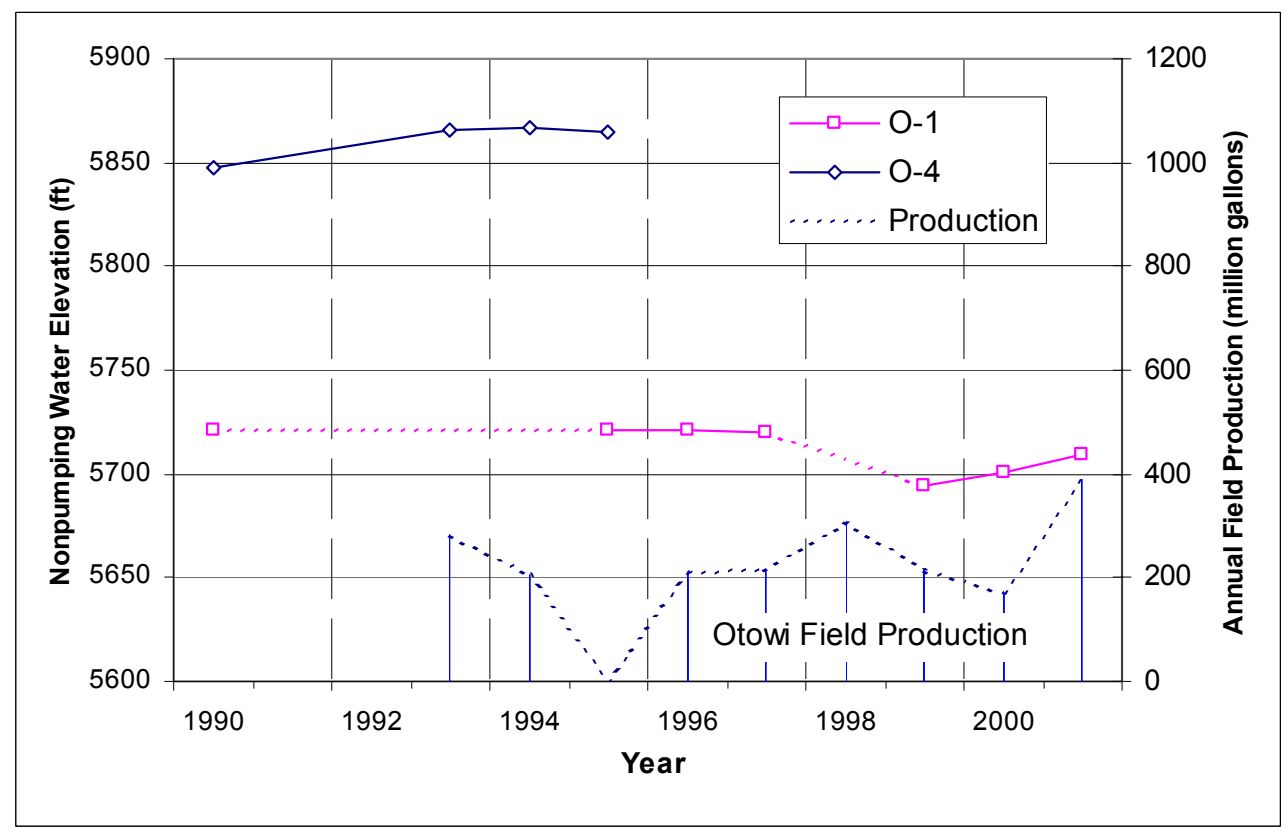

Figure 13. Average annual nonpumping water levels of wells in the Otowi field, 1990 to 2001 


\subsubsection{Test Wells}

The regional aquifer test (observation) wells at Los Alamos are listed in Table 5 and the locations of the test wells are shown in Figure 14. The historical water-level data from the regional aquifer test wells are tabulated in Appendix Table E-1. The test well water-level data were compiled from the original records in the files of the Water Quality and Hydrology Group (RRES-WQH) and from previous water supply reports (e.g., McLin et al. 1998). Since 1992, WQH personnel have conducted a program to equip and maintain test wells with an automatic water-level recording device (McLin 1996). Some of the data in Appendix F represent averages when more than one measurement was obtained in a given year.

Table 5

Regional Aquifer Test Wells at Los Alamos

\begin{tabular}{|l|r|r|r|r|r|r|}
\hline \multicolumn{1}{|c|}{ Well } & Status & $\begin{array}{c}\text { Date } \\
\text { Completed }\end{array}$ & $\begin{array}{c}\text { Total } \\
\text { Depth (ft) }\end{array}$ & X-Coord (ft) & Y-Coord (ft) & $\begin{array}{c}\text { Surface } \\
\text { Elevation (ft) }\end{array}$ \\
\hline TW-1 & Monitor Well & Jan-50 & 642 & $1,650,041.5$ & $1,772,076.9$ & 6369.2 \\
\hline TW-2 & Monitor Well & Nov-49 & 834 & $1,634,231.3$ & $1,777,267.9$ & 6648.6 \\
\hline TW-3 & Monitor Well & Nov-49 & 815 & $1,637,727.5$ & $1,773,138.1$ & 6595.3 \\
\hline TW-4 & Monitor Well & Mar-50 & 1205 & $1,624,028.1$ & $1,777,680.1$ & 7244.6 \\
\hline TW-8 & Monitor Well & Dec-60 & 1065 & $1,632,573.9$ & $1,769,506.8$ & 6877.6 \\
\hline DT-5A & Monitor Well & Jan-60 & 1821 & $1,625,310.0$ & $1,754,789.0$ & 7144.0 \\
\hline DT-9 & Monitor Well & Feb-60 & 1501 & $1,628,993.6$ & $1,751,492.6$ & 6935.0 \\
\hline DT-10 & Monitor Well & Mar-60 & 1409 & $1,628,988.5$ & $1,754,448.8$ & 7020.0 \\
\hline
\end{tabular}

Source: LANL RRES-WQH WQDB and Purtymun 1995. The coordinate system is NM State Plane, North American Datum of 1983 (NAD-83).

\subsubsection{Regional Aquifer Characterization Wells}

In 1998, a program to characterize the regional aquifer was initiated at LANL that included the planned installation of 32 characterization wells (called R-wells) to the regional aquifer (LANL 1998). As of 2001, nine characterization wells have been drilled to the regional aquifer. The locations of the R-wells are shown in Figure 14, and summary information for these wells is listed in Table 6. Well coordinates and water-level data were obtained from the respective R-well completion reports (Ball et al. 2002; Broxton et al. 2001a; Broxton et al. 2001b; Broxton et al. 2001c; Broxton et al. 2002; Kopp et al. 2002; Longmire et al. 2001; Stone et al. 2002; and Vaniman et al. 2002). 


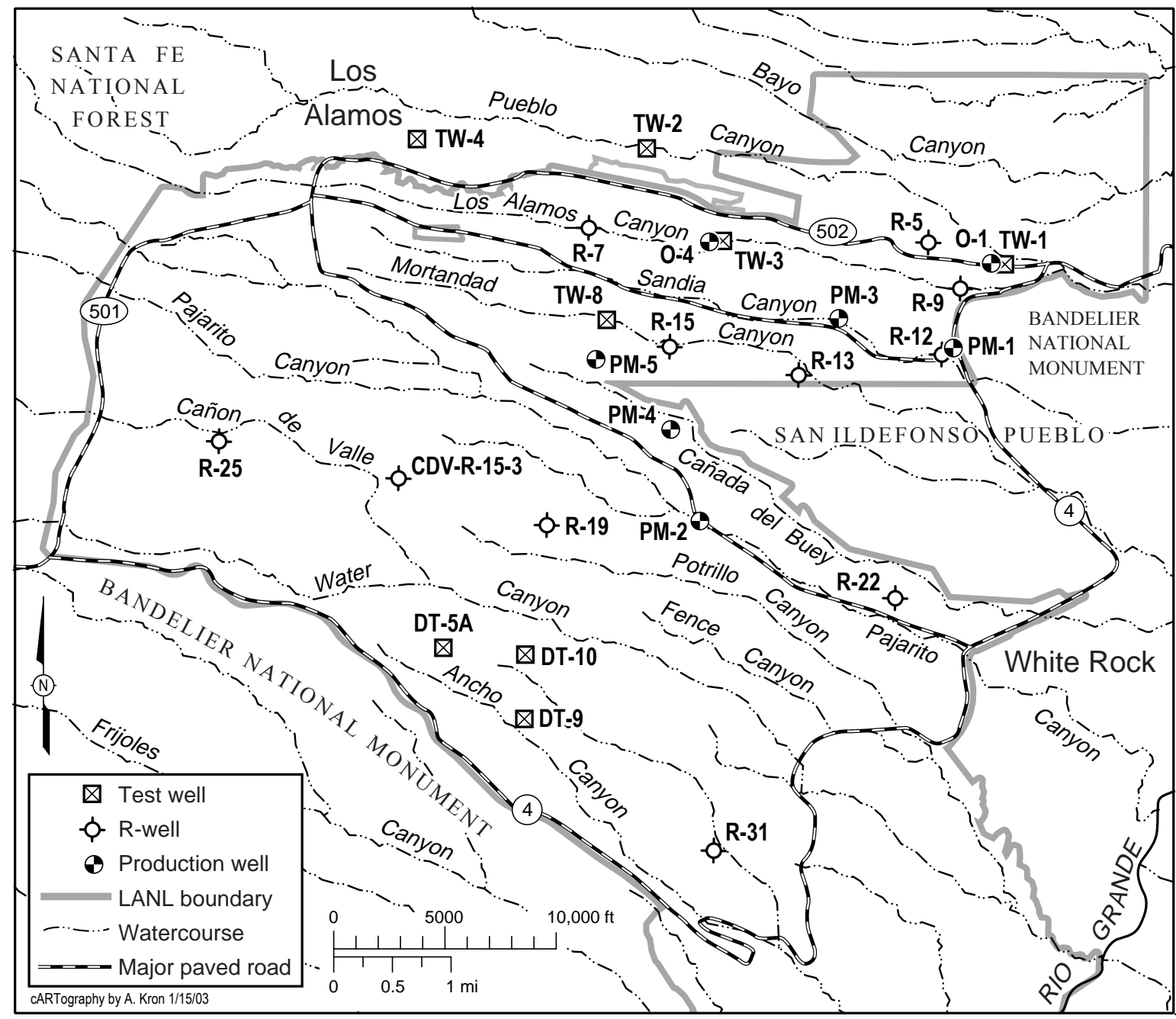

Figure 14. Locations of test wells and regional aquifer characterization wells

Table 6

Regional Aquifer Characterization Wells at Los Alamos

\begin{tabular}{|l|c|c|c|c|c|c|r|r|r|r|}
\hline \multicolumn{1}{|c|}{ Well } & Status & $\begin{array}{c}\text { Date } \\
\text { Completed }\end{array}$ & $\begin{array}{c}\text { Total } \\
\text { Depth } \\
\mathbf{f f t}\end{array}$ & $\begin{array}{c}\text { Depth } \\
\text { Completed } \\
(\mathbf{f t})\end{array}$ & X-Coord (ft) & Y-Coord (ft) & $\begin{array}{c}\text { Surface } \\
\text { Elevation } \\
\text { (ft) }\end{array}$ & $\begin{array}{c}\text { Depth } \\
\text { to } \\
\text { Water } \\
\text { (ft) }\end{array}$ & $\begin{array}{c}\text { Water } \\
\text { Elevation } \\
\text { (ft) }\end{array}$ & $\begin{array}{c}\text { Water } \\
\text { Level Date }\end{array}$ \\
\hline CDV-R-15-3 & Monitor Well & $09 / 24 / 00$ & 1722 & 1675 & $1,623,221.0$ & $1,762,349.2$ & $7,258.9$ & $1,246.0$ & 6012.9 & $05 / 03 / 00$ \\
\hline R-5 & Monitor Well & $06 / 19 / 01$ & 902 & 864 & $1,646,707.0$ & $1,773,063.0$ & $6,472.6$ & 685.0 & 5787.6 & $05 / 20 / 01$ \\
\hline R-7 & Monitor Well & $02 / 26 / 01$ & 1097 & 977 & $1,631,666.0$ & $1,773,653.0$ & $6,779.2$ & 902.8 & 5876.4 & $01 / 12 / 01$ \\
\hline R-9 & Monitor Well & $10 / 18 / 99$ & 771 & 758 & $1,648,236.5$ & $1,770,847.1$ & $6,382.8$ & 688.0 & 5694.8 & $03 / 03 / 98$ \\
\hline R-12 & Monitor Well & $03 / 21 / 00$ & 886 & 869 & $1,647,424.2$ & $1,767,913.4$ & $6,499.6$ & 805.0 & 5694.6 & $01 / 09 / 98$ \\
\hline R-13 & Monitor Well & $10 / 30 / 01$ & 1133 & 1029 & $1,640,991.7$ & $1,766,994.2$ & $6,673.1$ & 834.0 & 5839.1 & $09 / 20 / 01$ \\
\hline R-15 & Monitor Well & $09 / 07 / 99$ & 1107 & 1031 & $1,635,308.6$ & $1,768,272.5$ & $6,820.0$ & 964.0 & 5856.0 & $08 / 31 / 99$ \\
\hline R-19 & Monitor Well & $09 / 19 / 00$ & 1903 & 1877 & $1,629,918.4$ & $1,760,252.1$ & $7,066.3$ & $1,178.0$ & 5888.3 & $03 / 16 / 00$ \\
\hline R-22 & Monitor Well & $12 / 10 / 00$ & 1489 & 1473 & $1,645,324.4$ & $1,757,111.1$ & $6,650.5$ & 883.0 & 5767.5 & $10 / 01 / 00$ \\
\hline R-25 & Monitor Well & $09 / 28 / 00$ & 1942 & 1934 & $1,615,178.4$ & $1,764,060.5$ & $7,516.1$ & $1,286.0$ & 6230.1 & $04 / 21 / 99$ \\
\hline R-31 & Monitor Well & $12 / 01 / 00$ & 1103 & 1078 & $1,637,353.8$ & $1,745,648.4$ & $6,362.5$ & 525.0 & $5,837.5$ & $02 / 05 / 00$ \\
\hline
\end{tabular}

Note: Water level dates approximate. The coordinate system is NM State Plane, North American Datum of 1983 (NAD-83); coordinates and elevations shown are for the brass cap in the concrete pad. 
Table 6 lists the initial water levels to the regional aquifer that were observed in the characterization wells. The regional aquifer was encountered at an elevation of $5694.6 \mathrm{ft}$ in well R-12 and at a similar elevation $5694.8 \mathrm{ft}$ in well R-9. Groundwater at the top of the regional saturated zone at these wells is unconfined (Broxton et al. 2001a). The elevation at the top of the regional aquifer in wells R-9 and R-12 is lower than nonpumping water levels in supply wells PM-1 (5761 ft) and O-1 (5710 ft). The higher static water levels in nearby water supply wells probably result from their long screen lengths, allowing multiple zones to contribute to a composite hydraulic head in an area of upward gradient. Well PM-1 is screened over a 1554-ft interval; the higher water levels in the supply wells suggest that higher head zones occur in the regional aquifer at depths greater than those penetrated by shallower wells R-12 and R-9. In this area of the Pajarito Plateau, the deeper units of the regional aquifer may have upward hydraulic gradients (Broxton et al. 2001a; Broxton et al. 2001b). Additional information about recent water-level data and regional aquifer gradient is reported in the LANL Annual Groundwater Status Report (e.g., Nylander et al. 2002).

\subsubsection{Summary of Long-Term Water Levels}

Collectively, the individual trends in water levels near Los Alamos reflect a plateau-wide decline in regional aquifer water levels in response to municipal water production. This decline is gradual and has been about 0.7 to $2 \mathrm{ft}$ per year for production wells and less than $1 \mathrm{ft}$ per year for observation test wells. The highest declines have been observed in the Guaje field where nonpumping water levels in 2001 were about $91 \mathrm{ft}$ lower than in 1951. The initial water levels of the Guaje replacement wells in 1998 were 32 to $57 \mathrm{ft}$ lower than the initial water levels of adjacent original Guaje wells.

Approximately static water levels in well PM-4 in the spring of 1999 and 2001, after the well had not operated for several months, were about $19 \mathrm{ft}$ below the initial water level of 1981 . When production wells are taken off-line for pump replacement or repair, water levels have returned to within about $25 \mathrm{ft}$ of initial static levels within 6 to 12 months.

The long-term water-level observations from production and test wells at Los Alamos are consistent with the formation of a cone of depression in response to pumping. Maximum declines are located at the well fields and smaller declines are observed in neighboring areas. The creation of a cone of depression in response to pumping is an essential component in the production of groundwater (e.g., Freeze and Cherry 1979). Production wells at Los Alamos were constructed to operate appropriately at present water levels. Thus, the water-level trends suggest no adverse impacts by production on long-term water supply sustainability at Los Alamos.

\subsection{SUMMARY}

In 1998, DOE transferred the operation of the water supply wells at Los Alamos to Los Alamos County. Four replacement wells were installed in the Guaje field in 1998 and were placed in service in 1999. Six of the old Guaje wells were plugged or abandoned in 1999. Wells in the Otowi and Pajarito fields continued to operate adequately. The operation of the wells and well fields from 1998 through 2001 provided adequate supply for Los Alamos and LANL.

Production of potable municipal water supplies from 1998 through 2001 ranged from $1322.8 \mathrm{Mg}$ in 1999 to $1506.1 \mathrm{Mg}$ in 2000; production of groundwater was from the Guaje, Pajarito, and Otowi fields. Nonpotable water use from Los Alamos reservoir ranged from zero gallons in 2001 to $9.3 \mathrm{Mg}$ in 2000; this water is used to irrigate public parks and athletic fields in Los Alamos. Use of water from Los Alamos reservoir ended in 2000 after the Cerro Grande fire, when resulting storm runoff filled the reservoir with ash and sediment. 
The long-term trends in water levels reflect a plateau-wide decline in regional aquifer water levels in response to municipal water production. This average annual decline is gradual and has ranged from 0.7 to $2 \mathrm{ft}$ per year for production wells and from 0.4 to $0.9 \mathrm{ft} / \mathrm{yr}$ for observation (test) wells. The largest declines are in the Guaje field where nonpumping water levels were about $91 \mathrm{ft}$ lower in 2001 than in 1951. The initial water levels of the Guaje replacement wells were 32 to $57 \mathrm{ft}$ lower than initial water levels of adjacent original Guaje wells. When production wells are taken off-line for pump replacement or repair, water levels have returned to within about $25 \mathrm{ft}$ of initial static levels within 6 to 12 months.

The long-term water level declines in production and observation wells at Los Alamos are consistent with the formation of a cone of depression in response to pumping. Based on review of the available waterlevel data, the water-level trends suggest no adverse impacts by production on long-term water supply sustainability at Los Alamos.

\subsection{ACKNOWLEDGEMENTS}

The authors would like to thank all those that have contributed to the production of this report. Los Alamos County Utility Department employees gathered and compiled much of the production and waterlevel data presented in this report. Thanks especially go to Timothy Glasco, Charlie Brown, Pete Padilla, and John Fesser for their assistance in making data available and for discussion about the transfer and operation of the water supply system and for review of the report.

Thanks to Steven Rae (RRES-WQH) for programmatic support for preparation of this report. Recognition and appreciation also go to Bruce Gallaher, Steve McLin, and Robert Beers (RRES-WQH) for technical review of the report and for providing many very helpful comments. Neal Tapia (RRES-WQH) collected and compiled the water-level data for test wells. Alan Woodward (RRES-WQH) provided GIS data and well location coordinate support. Andrea Kron provided cartography for the map figures.

Caitlin Parson (SAIC) assisted with data entry, data management, and compilation of references. Jon Marin (SAIC) provided helpful review of the report. Thanks also to Gilbert A. Montoya (FWO-UI) who provided LANL water-use data and to Vences Abeyta (SSS-UWGW) who provided historical production data for this report.

Thanks to Christy Flaming for designing the cover, to Randi Moore for compositing this report, and to Meena Sachdeva for editing it.

\subsection{REFERENCES}

Ball, T., M. Everett, P. Longmire, D. Vaniman, W. Stone, D. Larssen, K. Greene, N. Clayton, and S. McLin, February 2002, "Characterization Well R-22 Completion Report," Los Alamos National Laboratory report LA-13893-MS, Los Alamos, New Mexico (Ball et al. 2002).

Beers, R.S., C.D. Ann Bretzke, S.L. Evans-Carmichael, P.A. Vardaro-Charles, S.C. Fong, T.A. Glasco, S.W. Hanson, S. Kerven, G.A. Montoya, and C. C. Pergler, 2001, "LANL Site-Wide Water Conservation Program Plan," Los Alamos National Laboratory report LA-UR-01-6377, Los Alamos, New Mexico (Beers et al. 2001).

Broxton, D.E., R. Warren, D. Vaniman, B. Newman, A. Crowder, M. Everett, R. Gilkeson, P. Longmire, J. Marin, W. Stone, S. McLin, and D. Rogers, May 2001, "Characterization Well R-12 Completion Report," Los Alamos National Laboratory report LA-13822-MS, Los Alamos, New Mexico (Broxton et al. 2001a). 
Broxton, D., R. Gilkeson, P. Longmire, J. Marin, R. Warren, D. Vaniman, A. Crowder, B. Newman, B. Lowry, D. Rogers, W. Stone, S. McLin, G. WoldeGabriel, D. Daymon, and D. Wycoff, May 2001, "Characterization Well R-9 Completion Report," Los Alamos National Laboratory report LA-13742-MS, Los Alamos, New Mexico (Broxton et al. 2001b).

Broxton, D., D. Vaniman, W. Stone, S. McLin, J. Marin, R. Koch, R. Warren, P. Longmire, D., Rogers, N. Tapia, May 2001, "Characterization Well R-19 Completion Report," Los Alamos National Laboratory report LA-13823-MS, Los Alamos, New Mexico (Broxton et al. 2001c).

Broxton, D., R. Warren, P. Longmire, R. Gilkeson, S. Johnson, D. Rogers, W. Stone, B. Newman, M. Everett, D. Vaniman, S. McLin, J. Skalski, and D. Larssen, March 2002, "Characterization Well R-25 Completion Report," Los Alamos National Laboratory report LA-13909-MS, Los Alamos, New Mexico (Broxton et al. 2002).

Environmental Surveillance Program, September 1999, "Environmental Surveillance at Los Alamos during 1998," Los Alamos National Laboratory report LA-13633-ENV, Los Alamos, New Mexico (ESP 1999).

Environmental Surveillance Program, December 2000, "Environmental Surveillance at Los Alamos during 1999," Los Alamos National Laboratory report LA-13775-ENV, Los Alamos, New Mexico (ESP 2000).

Environmental Surveillance Program, October 2001, "Environmental Surveillance at Los Alamos during 2000," Los Alamos National Laboratory report LA-13861-ENV, Los Alamos, New Mexico (ESP 2001).

Environmental Surveillance Program, September 2002, "Environmental Surveillance at Los Alamos during 2001," Los Alamos National Laboratory report LA-13979-ENV, Los Alamos, New Mexico (ESP 2002).

Freeze, R.A., and J.A. Cherry, 1979, Groundwater, Prentice-Hall, Inc., Englewood Cliffs, New Jersey (Freeze and Cherry 1979).

Glasco, T.A., August 13, 2002, Telephone conversation between Richard Koch and Tim Glasco, LAC Utilities Department, about LANL and Los Alamos County water use (Glasco 2002).

Koch, R.J., P. Longmire, D.B. Rogers, and K. Mullen, 1999, "Report of Testing and Sampling of Municipal Supply Well PM-4," Los Alamos National Laboratory report LA-13648, Los Alamos, New Mexico (Koch et al. 1999).

Kopp, H.W., A.J. Crowder, M.C. Everett, D.T. Vaniman, D.D. Hickmott, W.J. Stone, N. Clayton, S.G. Pearson, and D.E. Larssen, April 2002, "Well CdV-R-15-3 Completion Report," Los Alamos National Laboratory report LA-13906-MS, Los Alamos, New Mexico (Kopp et al. 2002).

LANL (Los Alamos National Laboratory), May 22, 1998, "Hydrogeologic Workplan," Los Alamos, New Mexico (LANL 1998).

LANL (Los Alamos National Laboratory), 2002, "Annual Summaries," LANL Weather Machine weather data website accessed December 11, 2002, http://weather.lanl.gov/html/annualsummaries.html; compilation of historical precipitation raw data for Los Alamos available at http://weather.lanl.gov/.

Longmire, P., D. Broxton, W. Stone, B. Newman, R. Gilkeson, J. Marin, D. Vaniman, D. Counce, D. Rogers, R. Hull, S. McLin, and R. Warren, May 2001, "Characterization Well R-15 Completion Report," Los Alamos National Laboratory report LA-13749-MS, Los Alamos, New Mexico (Longmire et al. 2001). 
McLin, S.G., September 1996, "Analysis of Water Level Fluctuations in Pajarito Plateau Wells," in New Mexico Geological Society Guidebook, 47th Field Conference, Jemez Mountains Region, New Mexico, pp. 421-426 (McLin 1996).

McLin, S.G., W.D. Purtymun, and M.N. Maes, April 1997, "Water Supply at Los Alamos during 1995," Los Alamos National Laboratory report LA-13216-PR, Los Alamos, New Mexico (McLin et al. 1997a).

McLin, S.G., W.D. Purtymun, and M.N. Maes, December 1998, "Water Supply at Los Alamos during 1997," Los Alamos National Laboratory report LA-13548-PR (McLin et al. 1998).

Nylander, C., T. Ball, K. Bitner, K. Henning, E. Keating, P. Longmire, B. Robinson, D. Rogers, W. Stone, D. Vaniman, April 2002, "Groundwater Annual Status Report for Fiscal Year 2001," Los Alamos National Laboratory report LA-13931-SR, Los Alamos, New Mexico (Nylander et al. 2002).

Purtymun, W.D., and J.W. Herceg, 1972, "Summary of the Los Alamos Municipal Well-Field Characteristics, 1947-1971," Los Alamos Scientific Laboratory report LA-5040-MS, Los Alamos, New Mexico (Purtymun and Herceg 1972).

Purtymun, W.D., and J.W. Herceg, 1976, "Water Supply at Los Alamos during 1975," Los Alamos Scientific Laboratory report LA-6461-MS, Los Alamos, New Mexico (Purtymun and Herceg 19726.

Purtymun, W.D., 1984, "Hydrologic Characteristics of the Main Aquifer in the Los Alamos Area: Development of Groundwater Supplies," Los Alamos National Laboratory LA-9957-MS, Los Alamos, New Mexico (Purtymun 1984).

Purtymun, W.D., and A.K. Stoker, 1988, "Current Status of Wells and Future Water Supply," Los Alamos National Laboratory report LA-11332-MS, Los Alamos, New Mexico (Purtymun and Stoker 1988).

Purtymun, W.D., 1995, "Geologic and Hydrologic Records of Observation Wells, Test Holes, Test Wells, Supply Wells, Springs, and Surface Water Stations in the Los Alamos Area," Los Alamos National Laboratory report LA-12883-MS, Los Alamos, New Mexico (Purtymun 1995).

Shomaker \& Associates, January 1999, "Well Report: Construction and Testing, Guaje Replacement Wells GR-1, GR-2, GR-3, and GR-4, Santa Fe County, New Mexico," John Shomaker \& Associates, Inc., report prepared for University of California, Los Alamos National Laboratory, Los Alamos, New Mexico, and Chavez-Grieves Consulting Engineers, Inc., Albuquerque, New Mexico (Shomaker \& Associates 1999).

Stone, W.J., D.T. Vaniman, P. Longmire, D.E. Broxton, M.C. Everett, R. Lawrence, D.E. Larssen, April, 2002, "Characterization Well R-7 Completion Report," Los Alamos National Laboratory report LA-13932MS, Los Alamos, New Mexico (Stone et al. 2002).

Vaniman, D., J. Marin, W. Stone, B. Newman, P. Longmire, N. Clayton, R. Lewis, R. Koch, S. McLin, G. WoldeGabriel, D. Counce, D. Rogers, R. Warren, E. Kluk, S. Chipera, D. Larssen, W. Kopp, March 2002, "Characterization Well R-31 Completion Report," Los Alamos National Laboratory report LA-13910MS, Los Alamos, New Mexico (Vaniman et al. 2002).

Watson, J.B., and D.H. Rappuhn, December 1999, "Well Report: Plugging and Abandonment of Guaje Wells G-1, G-2, G-3, G-4, G-5, and G-6, Los Alamos, New Mexico," report prepared by John Shomaker \& Associates, Inc., Albuquerque, New Mexico, for University of California, Los Alamos National Laboratory, Los Alamos, New Mexico, and Chavez-Grieves Consulting Engineers, Inc., Albuquerque, New Mexico (Watson and Rappuhn 1999). 


\section{Appendix A}

\section{List of Water Supply Reports-1972-1997}





\section{Appendix A List of Water Supply Reports-1972-1997}

Previous water supply reports, published by the Los Alamos National Laboratory, are listed below in chronological order.

W.D Purtymun and J.W. Herceg, "Water Supply at Los Alamos during 1971," Los Alamos Scientific Laboratory report LA-5039-MS (1972).

W.D. Purtymun and J.W. Herceg, "Water Supply at Los Alamos during 1972," Los Alamos Scientific Laboratory report LA-5296-MS (1973).

W.D. Purtymun and J.W. Herceg, "Water Supply at Los Alamos during 1973," Los Alamos Scientific Laboratory report LA-5636-MS (1974).

W.D. Purtymun and J.W. Herceg, "Water Supply at Los Alamos during 1974," Los Alamos Scientific Laboratory report LA-5998-MS (1975).

W.D. Purtymun and J.W. Herceg, "Water Supply at Los Alamos during 1975," Los Alamos Scientific Laboratory report LA-6461-MS (1976).

W. D. Purtymun and J.W. Herceg, "Water Supply at Los Alamos during 1976," Los Alamos Scientific Laboratory report LA-6814-PR (1977).

W.D. Purtymun and J.W. Herceg, "Water Supply at Los Alamos during 1977," Los Alamos Scientific Laboratory report LA-7436-MS (1978).

W.D. Purtymun and J.W. Herceg, "Water Supply at Los Alamos during 1978," Los Alamos Scientific Laboratory report LA-8074-PR (1979).

W.D. Purtymun and J.W. Herceg, "Water Supply at Los Alamos during 1979," Los Alamos Scientific Laboratory report LA-8504-PR (1980).

W. D. Purtymun and M.N. Maes, "Water Supply at Los Alamos during 1980," Los Alamos National Laboratory report LA-8977-PR (1981).

W. D. Purtymun, N.M. Becker, and M.N. Maes, "Water Supply at Los Alamos during 1981," Los Alamos National Laboratory report LA-9734-PR (1983).

W.D. Purtymun, N.M. Becker, and M.N. Maes, "Water Supply at Los Alamos during 1982," Los Alamos National Laboratory report LA-9896-PR (1984).

W.D. Purtymun, N.M. Becker, M.N. Maes, "Water Supply at Los Alamos during 1983," Los Alamos National Laboratory report LA-10327-PR (1985).

W. D. Purtymun, N.M Becker, M.N. Maes, "Water Supply at Los Alamos during 1984," Los Alamos National Laboratory report LA-10584-PR (1986).

W.D. Purtymun, N.M. Becker, and M.N. Maes, "Water Supply at Los Alamos during 1985," Los Alamos National Laboratory report LA-10835-PR (1986).

W.D. Purtymun, A.K. Stoker, and M.N. Maes, "Water Supply at Los Alamos during 1986," Los Alamos National Laboratory report LA-11046-PR (1987). 
W.D. Purtymun, A.K. Stoker, and M.N. Maes, "Water Supply at Los Alamos during 1987," Los Alamos National Laboratory report LA-11478-PR (1989).

W.D. Purtymun, M.N. Maes, and S.G. McLin, "Water Supply at Los Alamos during 1988," Los Alamos National Laboratory report LA-11679-PR (1989).

A.K. Stoker, S.G. McLin, W.D. Purtymun, M.N. Maes, and B.G. Hammock, "Water Supply at Los Alamos during 1989," Los Alamos National Laboratory report LA-12276-PR (1992).

W.D. Purtymun, S.G. McLin, A.K. Stoker, M.N. Maes, and B. G. Hammock, "Water Supply at Los Alamos during 1990," Los Alamos National Laboratory report LA-12471-PR (1993).

W.D. Purtymun, S. G. McLin, A.K. Stoker, and M.N. Maes, "Water Supply at Los Alamos during 1991," Los Alamos National Laboratory report LA-12770-PR (1994).

W.D. Purtymun, S.G. McLin, A.K. Stoker, and M.N. Maes, "Water Supply at Los Alamos during 1992," Los Alamos National Laboratory report LA-12926-PR (1995).

W.D. Purtymun, A.K. Stoker, S.G. McLin, M.N. Maes, and T.A. Glasco, "Water Supply at Los Alamos during 1993," Los Alamos National Laboratory report LA-12951-PR (1995).

S.G. McLin, W.D. Purtymun, A.K. Stoker, and M.N. Maes, "Water Supply at Los Alamos during 1994," Los Alamos National Laboratory report LA-10357-PR (1996).

S.G. McLin, W.D. Purtymun, and M.N. Maes, "Water Supply at Los Alamos during 1995," Los Alamos National Laboratory report LA-13216-PR (April 1997a).

S.G. McLin, W.D. Purtymun, M.N. Maes, and P.A. Longmire, "Water Supply at Los Alamos during 1996, Los Alamos National Laboratory report LA-13371-PR (December 1997b).

S.G. McLin, W.D. Purtymun, and M.N. Maes, 1998, "Water Supply at Los Alamos during 1997," Los Alamos National Laboratory Report LA-13548-PR (December 1998). 


\title{
Appendix B
}

\author{
Annual Water Production Data
}



Appendix B. Annual Water Production Data

Table B-1

Water Production from Well Fields, Springs, and Reservoirs at Los Alamos: 1947-2001 (millions of gallons)

\begin{tabular}{|c|c|c|c|c|c|c|c|c|c|c|}
\hline & \multicolumn{5}{|c|}{ Ground Water } & \multicolumn{4}{|c|}{ Springs and Reservoirs } & \multirow[b]{2}{*}{$\begin{array}{c}\text { Total } \\
\text { Annual } \\
\text { Usage }\end{array}$} \\
\hline Year & $\begin{array}{c}\text { Los } \\
\text { Alamos } \\
\text { Well Field }\end{array}$ & $\begin{array}{c}\text { Guaje } \\
\text { Well } \\
\text { Field }\end{array}$ & $\begin{array}{c}\text { Pajarito } \\
\text { Well } \\
\text { Field }\end{array}$ & $\begin{array}{c}\text { Otowi } \\
\text { Well } \\
\text { Field }\end{array}$ & $\begin{array}{c}\text { Ground } \\
\text { Water } \\
\text { Total }\end{array}$ & \begin{tabular}{|c|} 
Water \\
Canyon \\
Gallery \\
Spring
\end{tabular} & $\begin{array}{c}\text { Los } \\
\text { Alamos } \\
\text { Reservoir }\end{array}$ & $\begin{array}{c}\text { Guaje } \\
\text { Reservoir }\end{array}$ & \begin{tabular}{|c} 
Spring- \\
Reservoir \\
Total \\
\end{tabular} & \\
\hline 1947 & 147 & & & & 147 & 84.0 & 21.7 & 87.8 & 194 & 341 \\
\hline 1948 & 264 & & & & 264 & 97.0 & 21.9 & 119.8 & 239 & 503 \\
\hline 1949 & 302 & & & & 302 & 92.0 & 14.7 & 116.1 & 223 & 525 \\
\hline 1950 & 547 & 3 & & & 550 & 54.0 & 20.6 & 79.9 & 155 & 705 \\
\hline 1951 & 702 & 68 & & & 770 & 39.0 & 10.5 & 41.0 & 91 & 861 \\
\hline 1952 & 448 & 350 & & & 798 & 48.0 & 33.6 & 131.0 & 213 & 1,011 \\
\hline 1953 & 444 & 372 & & & 816 & 39.0 & 14.8 & 58.0 & 112 & 928 \\
\hline 1954 & 380 & 374 & & & 754 & 40.0 & 16.9 & 66.0 & 123 & 877 \\
\hline 1955 & 407 & 375 & & & 782 & 33.0 & 18.1 & 71.0 & 122 & 904 \\
\hline 1956 & 437 & 506 & & & 943 & 23.0 & 4.8 & 24.0 & 52 & 995 \\
\hline 1957 & 350 & 378 & & & 728 & 40.0 & 54.8 & 213.0 & 308 & 1,036 \\
\hline 1958 & 372 & 395 & & & 767 & 60.0 & 49.4 & 193.0 & 302 & 1,069 \\
\hline 1959 & 391 & 478 & & & 869 & 54.0 & 0.0 & 0.0 & 54 & 923 \\
\hline 1960 & 530 & 533 & & & 1,063 & 48.0 & 0.0 & 0.0 & 48 & 1,111 \\
\hline 1961 & 546 & 624 & & & 1,170 & 54.0 & 0.0 & 0.0 & 54 & 1,224 \\
\hline 1962 & 577 & 597 & & & 1,174 & 67.0 & 0.0 & 0.0 & 67 & 1,241 \\
\hline 1963 & 539 & 654 & & & 1,193 & 51.0 & 0.0 & 0.0 & 51 & 1,244 \\
\hline 1964 & 627 & 665 & & & 1,292 & 45.0 & 0.0 & 0.0 & 45 & 1,337 \\
\hline 1965 & 447 & 571 & 99 & & 1,117 & 72.0 & 0.0 & 0.0 & 72 & 1,189 \\
\hline 1966 & 450 & 613 & 127 & & 1,190 & 82.0 & 0.0 & 0.0 & 82 & 1,272 \\
\hline 1967 & 373 & 464 & 481 & & 1,318 & 56.0 & 0.0 & 0.0 & 56 & 1,374 \\
\hline 1968 & 345 & 474 & 584 & & 1,403 & 65.0 & 0.0 & 0.0 & 65 & 1,468 \\
\hline 1969 & 331 & 435 & 569 & & 1,335 & 80.0 & 0.0 & 0.0 & 80 & 1,415 \\
\hline 1970 & 360 & 423 & 595 & & 1,378 & 65.0 & 0.0 & 0.0 & 65 & 1,443 \\
\hline 1971 & 412 & 484 & 657 & & 1,553 & 37.0 & 0.0 & 0.0 & 37 & 1,590 \\
\hline 1972 & 380 & 467 & 662 & & 1,509 & 40.0 & 0.0 & 5.8 & 46 & 1,555 \\
\hline 1973 & 406 & 475 & 685 & & 1,566 & 49.0 & 0.0 & 9.7 & 59 & 1,625 \\
\hline 1974 & 369 & 453 & 802 & & 1,624 & 35.0 & 0.0 & 4.9 & 40 & 1,664 \\
\hline 1975 & 356 & 431 & 749 & & 1,536 & 42.0 & 0.0 & 5.3 & 47 & 1,583 \\
\hline 1976 & 343 & 531 & 817 & & 1,691 & 41.0 & 0.0 & 4.4 & 45 & 1,736 \\
\hline 1977 & 345 & 515 & 614 & & 1,474 & 57.0 & 0.0 & 4.1 & 61 & 1,535 \\
\hline 1978 & 302 & 444 & 690 & & 1,436 & 45.0 & 0.0 & 2.8 & 48 & 1,484 \\
\hline 1979 & 289 & 456 & 662 & & 1,407 & 44.0 & 1.3 & 3.7 & 49 & 1,456 \\
\hline 1980 & 339 & 485 & 743 & & 1,567 & 32.0 & 2.3 & 4.7 & 39 & 1,606 \\
\hline 1981 & 336 & 469 & 701 & & 1,506 & 45.0 & 2.1 & 2.7 & 50 & 1,556 \\
\hline 1982 & 317 & 422 & 773 & & 1,512 & 46.0 & 2.8 & 3.4 & 52 & 1,564 \\
\hline 1983 & 221 & 338 & 904 & & 1,463 & 38.0 & 1.4 & 3.4 & 43 & 1,506 \\
\hline 1984 & 326 & 460 & 780 & & 1,566 & 34.0 & 1.3 & 3.0 & 38 & 1,604 \\
\hline 1985 & 290 & 456 & 841 & & 1,587 & 37.0 & 0.9 & 2.8 & 41 & 1,628 \\
\hline 1986 & 179 & 460 & 858 & & 1,497 & 28.0 & 1.5 & 2.4 & 32 & 1,529 \\
\hline 1987 & 217 & 485 & 892 & & 1,594 & 34.0 & 3.2 & 2.8 & 40 & 1,634 \\
\hline 1988 & 158 & 477 & 824 & & 1,459 & 34.5 & 1.4 & 2.4 & 38 & 1,497 \\
\hline 1989 & 219 & 506 & 961 & & 1,686 & 23.0 & 3.3 & 4.6 & 31 & 1,717 \\
\hline 1990 & 187 & 532 & 923 & & 1,642 & 9.3 & 4.6 & 2.2 & 16 & 1,658 \\
\hline 1991 & 125 & 502 & 820 & & 1,447 & 12.0 & 2.4 & 1.5 & 16 & 1,463 \\
\hline 1992 & 13 & 472 & 1,044 & & 1,529 & 0.1 & 0.0 & 0.0 & 0 & 1,529 \\
\hline 1993 & & 298 & 876 & 284 & 1,458 & 6.4 & 0.5 & 0.0 & 7 & 1,465 \\
\hline 1994 & & 179 & 1,042 & 206 & 1,427 & 11.6 & 0.0 & 0.0 & 12 & 1,439 \\
\hline 1995 & & 230 & 1,126 & 0 & 1,356 & 1.6 & 1.6 & 0.0 & 3 & 1,359 \\
\hline 1996 & & 269 & 889 & 210 & 1,368 & 0.0 & 2.6 & 0.0 & 3 & 1,371 \\
\hline 1997 & & 272 & 798 & 216 & 1,286 & 0.0 & 2.4 & 0.0 & 2 & 1,288 \\
\hline 1998 & & 148 & 941 & 307 & 1,396 & 0.0 & 1.6 & 0.0 & 2 & 1,397 \\
\hline 1999 & & 319 & 791 & 213 & 1,323 & 0.0 & 2.0 & 0.0 & 2 & 1,325 \\
\hline 2000 & & 422 & 912 & 172 & 1,506 & 0.0 & 9.3 & 0.0 & 9 & 1,515 \\
\hline 2001 & & 269 & 785 & 389 & 1,443 & 0.0 & 0.0 & 0.0 & 0 & 1,443 \\
\hline Total & 16,445 & 22,079 & 28,016 & 1,997 & 68,537 & 2,171 & 330 & 1,277 & & 72,315 \\
\hline
\end{tabular}

Note: Guaje and Los Alamos reservoirs used as potable supply 1947-1958; irrigation only 1972 to 2000; Water Canyon gallery used for potable supply 1947-1987, and for nonpotable industrial supply 1988-1995.

Production from Guaje reservoir is estimated for 1951-1958 (McLin et al. 1998). 



\section{Appendix C}

Well Production Data and Aquifer Characteristics 

Appendix C. Well Production Data and Aquifer Characteristics

Table C-1

Well Production Characteristics, 1997 through 2001

\begin{tabular}{|c|c|c|c|c|c|c|c|c|c|c|c|c|c|c|c|}
\hline \multicolumn{6}{|c|}{ Production $\left(10^{6}\right.$ gallons $)$} & \multicolumn{5}{|c|}{$\%$ of Well Field Production } & \multicolumn{5}{|c|}{$\%$ of Total Production } \\
\hline Well & 1997 & 1998 & 1999 & 2000 & 2001 & 1997 & 1998 & 1999 & 2000 & 2001 & 1997 & 1998 & 1999 & 2000 & 2001 \\
\hline \multicolumn{16}{|l|}{ Guaje Field } \\
\hline $\mathrm{G}-1$ & 5.6 & 2.1 & 1.5 & & & 2.1 & 1.4 & 0.5 & & & 0.4 & 0.1 & 0.1 & & \\
\hline G-2 & 81.1 & 43.4 & 45.4 & & & 30.6 & 29.2 & 14.2 & & & 6.3 & 3.1 & 3.4 & & \\
\hline G-4 & 5.4 & 0.03 & & & & 2.0 & 0.0 & 0.0 & & & 0.4 & 0.002 & & & \\
\hline G-5 & 82.3 & 6.5 & & & & 31.0 & 4.3 & 0.0 & & & 6.4 & 0.5 & & & \\
\hline G-6 & 18.8 & 46.8 & 12.9 & & & 7.1 & 31.5 & 4.0 & & & 1.5 & 3.4 & 1.0 & & \\
\hline G-1A & 72.3 & 49.8 & 74.8 & 78.1 & 86.5 & 27.2 & 33.5 & 23.5 & 18.5 & 32.1 & 5.6 & 3.6 & 5.7 & 5.2 & 6.0 \\
\hline G-2A & & & 82.0 & 178.0 & 148.2 & & & 25.7 & 42.2 & 55.0 & & & 6.2 & 11.8 & 10.3 \\
\hline G-3A & & & 40.8 & 102.8 & 28.0 & & & 12.8 & 24.4 & 10.4 & & & 3.1 & 6.8 & 1.9 \\
\hline G-4A & & & 61.2 & 61.7 & 6.5 & & & 19.2 & 14.6 & 2.4 & & & 4.6 & 4.1 & 0.4 \\
\hline G-5A & & & 0.2 & 1.6 & 0.2 & & & 0.1 & 0.4 & 0.1 & & & 0.02 & 0.1 & 0.01 \\
\hline Field Subtotal & 265.5 & 148.5 & 318.8 & 422.2 & 269.4 & 100.0 & 100.0 & 100.0 & 100.0 & 100.0 & 20.7 & 10.6 & 24.1 & 28.0 & 18.7 \\
\hline \multicolumn{16}{|l|}{ Otowi Field } \\
\hline O-1 & & 67.1 & 13.0 & 53.3 & 25.2 & & 21.9 & 6.1 & 31.0 & 6.5 & 0.0 & 4.8 & 1.0 & 3.5 & 1.7 \\
\hline $0-4$ & 219.2 & 239.7 & 200.5 & 119.0 & 363.4 & 100.0 & 78.1 & 93.9 & 69.0 & 93.5 & 17.1 & 17.2 & 15.2 & 7.9 & 25.2 \\
\hline Field Subtotal & 219.2 & 306.8 & 213.5 & 172.3 & 388.6 & 100.0 & 100.0 & 100.0 & 100.0 & 100.0 & 17.1 & 22.0 & 16.1 & 11.4 & 26.9 \\
\hline & & & & & & & & & & & & & & & \\
\hline \multicolumn{16}{|l|}{ Pajarito Field } \\
\hline PM-1 & 49.2 & 34.3 & 57.3 & 106.6 & 66.6 & 6.2 & 3.6 & 7.2 & 11.7 & 8.5 & 3.8 & 2.5 & 4.3 & 7.1 & 4.6 \\
\hline PM-2 & 158.1 & 386.2 & 249.2 & 333.9 & 303.3 & 19.8 & 41.1 & 31.5 & 36.6 & 38.6 & 12.3 & 27.7 & 18.8 & 22.2 & 21.0 \\
\hline PM-3 & 77.5 & 222.5 & 135.0 & 93.0 & 91.8 & 9.7 & 23.7 & 17.1 & 10.2 & 11.7 & 6.0 & 15.9 & 10.2 & 6.2 & 6.4 \\
\hline PM-4 & 414.7 & 74.9 & 112.2 & 192.8 & 197.8 & 51.9 & 8.0 & 14.2 & 21.2 & 25.2 & 32.3 & 5.4 & 8.5 & 12.8 & 13.7 \\
\hline PM-5 & 98.8 & 222.8 & 237.0 & 185.3 & 125.9 & 12.4 & 23.7 & 30.0 & 20.3 & 16.0 & 7.7 & 16.0 & 17.9 & 12.3 & 8.7 \\
\hline Field Subtotal & 798.4 & 940.6 & 790.6 & 911.6 & 785.4 & 100.0 & 100.0 & 100.0 & 100.0 & 100.0 & 62.2 & 67.4 & 59.8 & 60.5 & 54.4 \\
\hline & & & & & & & & & & & & & & & \\
\hline Total & $1,283.1$ & $1,395.9$ & $1,322.8$ & $1,506.1$ & $1,443.4$ & & & & & & 100.0 & 100.0 & 100.0 & \begin{tabular}{l|l}
100.0 \\
\end{tabular} & 100.0 \\
\hline
\end{tabular}

Table C-2

Average Pumping Rate, Drawdown, and Specific Capacity, 1997 - 2001

\begin{tabular}{|c|c|c|c|c|c|c|c|c|c|c|c|c|c|c|c|}
\hline \multirow[b]{2}{*}{ Well } & \multicolumn{5}{|c|}{ Average pumping rate (gpm) } & \multicolumn{5}{|c|}{ Average Drawdown (ft) } & \multicolumn{5}{|c|}{$\begin{array}{c}\text { Average Specific Capacity } \\
(\mathrm{gpm} / \mathrm{ft})\end{array}$} \\
\hline & 1997 & 1998 & 1999 & 2000 & 2001 & 1997 & 1998 & 1999 & 2000 & 2001 & 1997 & 1998 & 1999 & 2000 & 2001 \\
\hline \multicolumn{16}{|l|}{ Guaje Field } \\
\hline G-1 & 191 & 183 & 60 & & & 180 & - & - & & & 1.1 & - & - & & \\
\hline G-2 & 420 & 424 & 432 & & & 26 & 25.5 & - & & & 16.2 & 16.6 & - & & \\
\hline G-4 & 174 & 170 & & & & 185 & - & & & & 0.9 & - & & & \\
\hline G-5 & 419 & 374 & & & & - & - & & & & - & - & & & \\
\hline G-6 & 258 & 243 & 247 & & & 77 & 82.9 & - & & & 3.4 & 2.9 & - & & \\
\hline G-1A & 416 & 413 & 405 & 400 & 400 & 31 & 29.7 & - & 30.8 & 25.1 & 13.4 & 13.9 & - & 13.0 & 15.9 \\
\hline G-2A & & & 800 & 760 & 820 & & 48.9 & 45.9 & 56.2 & 54.5 & & & 17.4 & 13.5 & 15.1 \\
\hline G-3A & & & 656 & 580 & 650 & & 76.6 & - & 50.5 & - & & & - & 11.5 & - \\
\hline G-4A & & & 584 & 525 & 525 & & 75.5 & 87.1 & 75.4 & - & & & 6.7 & 7.0 & - \\
\hline G-5A & & & 400 & 400 & 375 & & 79.6 & - & 126.3 & - & & & - & 3.2 & - \\
\hline Field Total & 1,878 & 1808 & 3584 & 2665 & 2770 & & & & & & & & & & \\
\hline & & & & & & & & & & & & & & & \\
\hline \multicolumn{16}{|l|}{ Otowi Field } \\
\hline $0-1$ & & 918 & 973 & 973 & 973 & - & - & 100.3 & 133.8 & 141.3 & - & - & 9.7 & 7.3 & 6.9 \\
\hline $\mathrm{O}-4$ & 1,505 & 1,471 & 1,479 & 1,450 & 1,450 & - & - & - & - & - & - & - & - & - & - \\
\hline Field Total & 1,505 & 2,389 & 2,452 & 2,423 & 2,423 & & & & & & & & & & \\
\hline & & & & & & & & & & & & & & & \\
\hline \multicolumn{16}{|l|}{ Pajarito Field } \\
\hline PM-1 & 560 & 534 & 586 & 586 & 586 & 24 & 26.9 & - & - & - & 23.3 & 19.8 & - & - & - \\
\hline PM-2 & 1,260 & 1,243 & 1,275 & 1,275 & 1,275 & - & 73.2 & - & 67.0 & 64.5 & - & 17.0 & - & 19.0 & 19.8 \\
\hline PM-3 & 1,398 & 1,395 & 1,400 & 1,400 & 1,400 & 26 & 27.1 & - & - & - & 53.8 & 51.5 & - & - & - \\
\hline PM-4 & 1,323 & 1,224 & 1,400 & 1,330 & 1,330 & 49 & 36.0 & 51.5 & 50.8 & 52.7 & 27.0 & 34.0 & 27.2 & 26.2 & 25.2 \\
\hline PM-5 & 1,213 & 1,161 & 1,175 & 1,175 & 1,175 & 88 & 84.4 & - & 81.1 & - & 13.8 & 13.7 & - & 14.5 & - \\
\hline Field Total & 5,754 & 5,557 & 5,836 & 5,766 & 5,766 & & & & & & & & & & \\
\hline
\end{tabular}





\section{Appendix D}

\section{Annual Well Data, Aquifer Characteristics, and Water Levels for Active Wells}



Appendix D. Annual Well Data, Aquifer Characteristics, and Water Levels for Active Wells

Well G-1

\begin{tabular}{|c|c|c|c|c|c|c|c|c|}
\hline Year & $\begin{array}{l}\text { Pump } \\
\text { Time } \\
\text { (h) }\end{array}$ & $\begin{array}{c}\text { Production } \\
\left(10^{6} \text { gal. }\right)\end{array}$ & $\begin{array}{l}\text { Pump } \\
\text { Rate } \\
\text { (gpm) }\end{array}$ & $\begin{array}{l}\text { Average Wa } \\
\text { Nonpumping } \\
\text { (ft) }\end{array}$ & $\begin{array}{l}\text { ter Level } \\
\text { Pumping } \\
\text { (ft) }\end{array}$ & $\begin{array}{l}\text { Drawdown } \\
\text { (ft) }\end{array}$ & $\begin{array}{l}\text { Specific } \\
\text { Capacity } \\
\text { (gpm/ft) }\end{array}$ & $\begin{array}{c}\text { Nonpumping } \\
\text { Water Elevation } \\
\text { (ft) }\end{array}$ \\
\hline 1950 & - & 2.8 & - & 195 & - & - & - & 5778 \\
\hline 1951 & 1168 & 37.7 & 538 & 202 & 309 & 107 & 5.0 & 5771 \\
\hline 1952 & 2476 & 75.5 & 508 & 213 & 295 & 82 & 6.2 & 5760 \\
\hline 1953 & 3275 & 97.3 & 495 & 221 & 292 & 71 & 7.0 & 5752 \\
\hline 1954 & 2616 & 77.8 & 496 & 221 & 290 & 69 & 7.2 & 5752 \\
\hline 1955 & 2406 & 70.5 & 448 & 226 & 295 & 69 & 6.5 & 5747 \\
\hline 1956 & 2958 & 83.2 & 469 & 235 & 303 & 68 & 6.9 & 5738 \\
\hline 1957 & 2098 & 55.9 & 444 & 236 & 307 & 71 & 6.3 & 5737 \\
\hline 1958 & 2460 & 68.1 & 461 & 238 & 308 & 70 & 6.6 & 5735 \\
\hline 1959 & 2952 & 82.4 & 465 & 245 & 314 & 69 & 6.7 & 5728 \\
\hline 1960 & 3564 & 96.0 & 449 & 254 & 325 & 71 & 6.3 & 5719 \\
\hline 1961 & 4236 & 112.4 & 442 & 260 & 333 & 73 & 6.1 & 5713 \\
\hline 1962 & 3431 & 93.6 & 455 & 258 & 342 & 84 & 5.4 & 5715 \\
\hline 1963 & 4519 & 114.9 & 424 & 265 & 348 & 83 & 5.1 & 5708 \\
\hline 1964 & 4374 & 113.8 & 434 & 269 & 352 & 83 & 5.2 & 5704 \\
\hline 1965 & 3530 & 90.7 & 428 & 268 & 352 & 84 & 5.1 & 5705 \\
\hline 1966 & 4074 & 102.6 & 420 & 269 & 363 & 94 & 4.5 & 5704 \\
\hline 1967 & 2615 & 69.9 & 446 & 266 & 362 & 96 & 4.6 & 5707 \\
\hline 1968 & 2996 & 78.9 & 439 & 264 & 366 & 102 & 4.3 & 5709 \\
\hline 1969 & 2657 & 68.3 & 428 & 266 & 376 & 110 & 3.9 & 5707 \\
\hline 1970 & 2712 & 64.7 & 398 & 264 & 377 & 113 & 3.5 & 5709 \\
\hline 1971 & 2908 & 67.9 & 389 & 258 & 378 & 120 & 3.2 & 5715 \\
\hline 1972 & 2865 & 66.1 & 385 & 264 & 389 & 125 & 3.1 & 5709 \\
\hline 1973 & 2997 & 67.5 & 375 & 271 & 403 & 132 & 2.8 & 5702 \\
\hline 1974 & 2767 & 62.3 & 375 & 283 & 412 & 129 & 2.9 & 5690 \\
\hline 1975 & 2467 & 55.7 & 376 & 293 & 411 & 118 & 3.2 & 5680 \\
\hline 1976 & 2962 & 65.1 & 366 & - & - & - & - & - \\
\hline 1977 & 2734 & 57.9 & 353 & 275 & 426 & 151 & 2.3 & 5698 \\
\hline 1978 & 2656 & 56.0 & 351 & 270 & 419 & 149 & 2.4 & 5703 \\
\hline 1979 & 2998 & 61.7 & 343 & 271 & 422 & 151 & 2.3 & 5702 \\
\hline 1980 & 3459 & 68.3 & 329 & 273 & 428 & 155 & 2.1 & 5700 \\
\hline 1981 & 4427 & 81.6 & 307 & 275 & 444 & 169 & 1.8 & 5698 \\
\hline 1982 & 3678 & 69.0 & 313 & 278 & 443 & 165 & 1.9 & 5695 \\
\hline 1983 & 2871 & 52.2 & 303 & 272 & 443 & 171 & 1.8 & 5701 \\
\hline 1984 & 3804 & 62.8 & 275 & 276 & 448 & 172 & 1.6 & 5697 \\
\hline 1985 & 3004 & 48.3 & 268 & 278 & 450 & 172 & 1.6 & 5695 \\
\hline 1986 & 2027 & 30.3 & 249 & 279 & 450 & 171 & 1.5 & 5694 \\
\hline 1987 & 2070 & 29.2 & 235 & 280 & 451 & 171 & 1.4 & 5693 \\
\hline 1988 & 395 & 5.4 & 277 & 280 & 445 & 165 & 1.7 & 5693 \\
\hline 1989 & 2010 & 26.9 & 223 & 282 & 451 & 169 & 1.3 & 5691 \\
\hline 1990 & 2121 & 30.8 & 242 & 284 & 454 & 170 & 1.4 & 5689 \\
\hline 1991 & 1730 & 20.9 & 201 & 282 & 451 & 169 & 1.2 & 5691 \\
\hline 1992 & 1077 & 12.0 & 186 & 283 & 439 & 156 & 1.2 & 5690 \\
\hline 1993 & 2.5 & 0.03 & 200 & 280 & - & - & - & 5693 \\
\hline 1994 & 1585 & 18.5 & 195 & 277 & 451 & 174 & 1.1 & 5696 \\
\hline 1995 & 2542 & 28.5 & 187 & 278 & 450 & 172 & 1.1 & 5695 \\
\hline 1996 & 1128 & 12.9 & 191 & 274 & 449 & 175 & 1.1 & 5699 \\
\hline 1997 & 897 & 13.6 & 191 & 274 & 454 & 180 & 1.1 & 5699 \\
\hline 1998 & 197 & 2.1 & 183 & - & - & - & - & \\
\hline 1999 & 417 & 1.5 & 60 & - & - & - & - & \\
\hline 2000 & - & - & - & - & - & - & - & - \\
\hline 2001 & - & - & - & - & - & - & - & \\
\hline Total & 125,913 & 2832.0 & & & & & & \\
\hline Minimum & 2.5 & 0.03 & 60 & 195 & 290 & 68 & 1.1 & 5680 \\
\hline Maximum & 4519 & 114.9 & 538 & 293 & 454 & 180 & 7.2 & 5778 \\
\hline Average & 2570 & 56.6 & 347 & 262 & 388 & 125 & 3.5 & 5711 \\
\hline
\end{tabular}

Note: Well completed July 1950; initial depth to water: $192 \mathrm{ft}$; surface elevation: $5973 \mathrm{ft}$; plugged September 1999 
Well G-1A

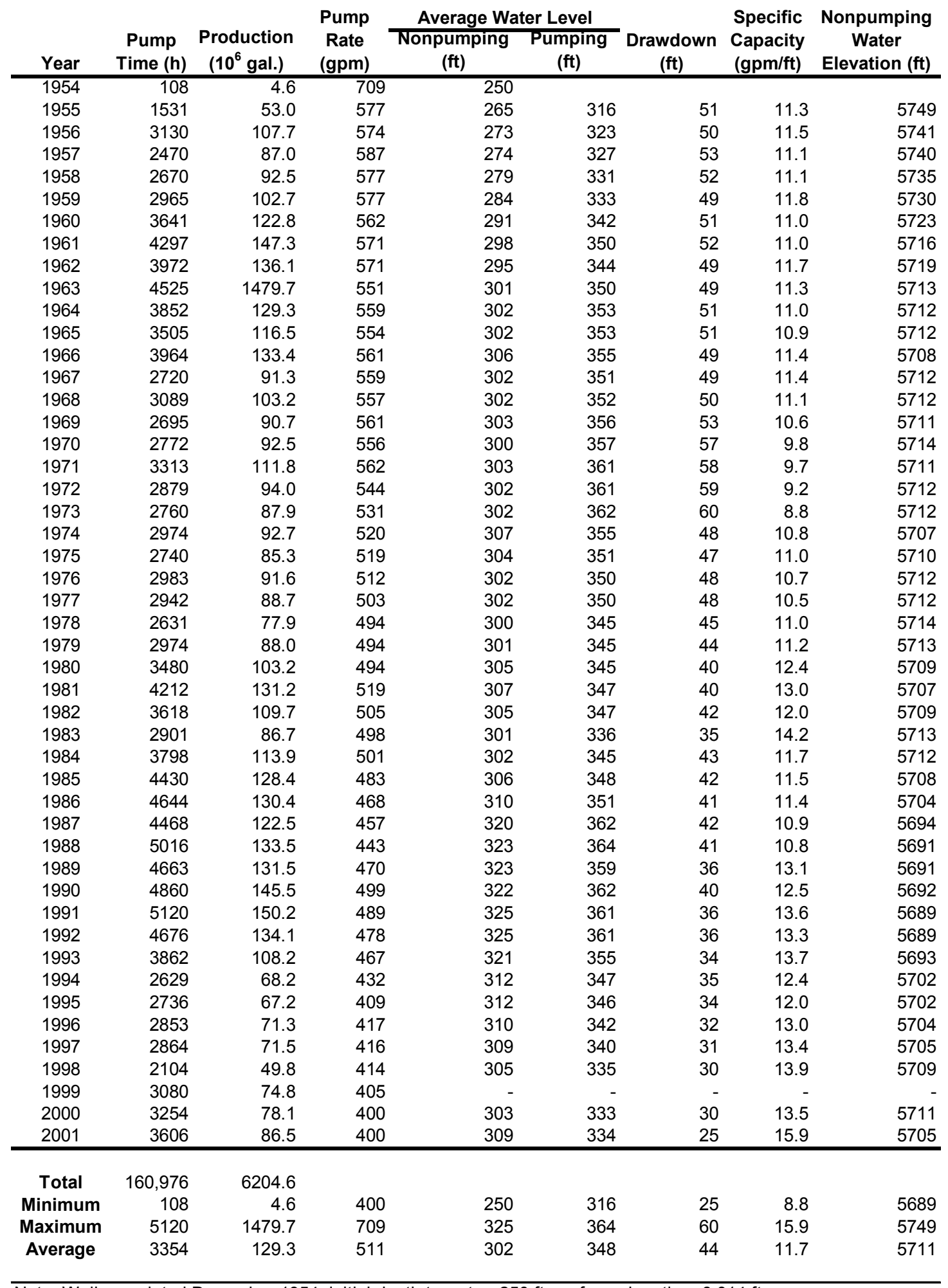

Note: Well completed December 1954; initial depth to water: $250 \mathrm{ft}$; surface elevation: 6,014 ft. 
Well G-2

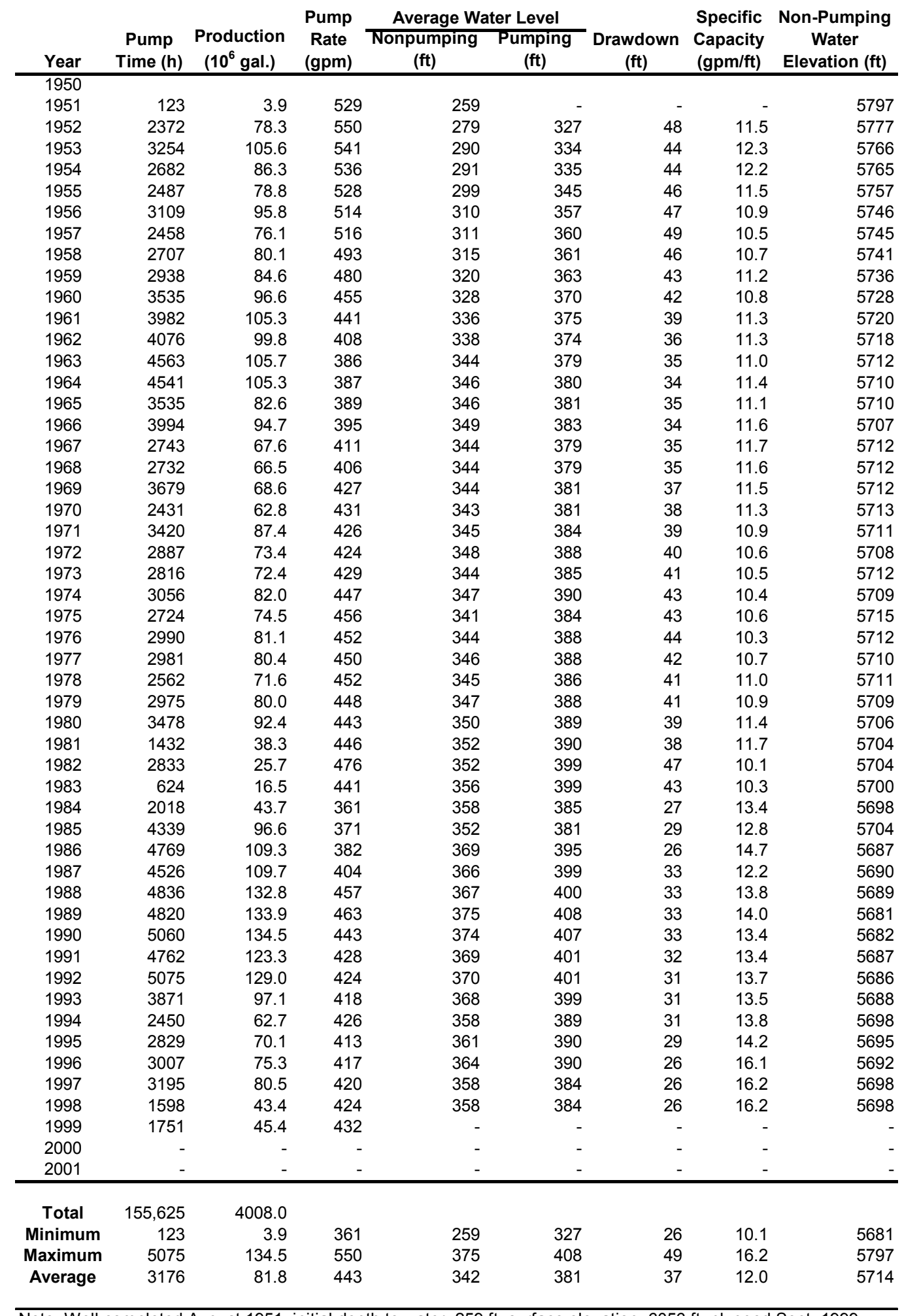

Note: Well completed August 1951; initial depth to water: 259 ft; surface elevation: 6056 ft; plugged Sept. 1999. 
Well G-3

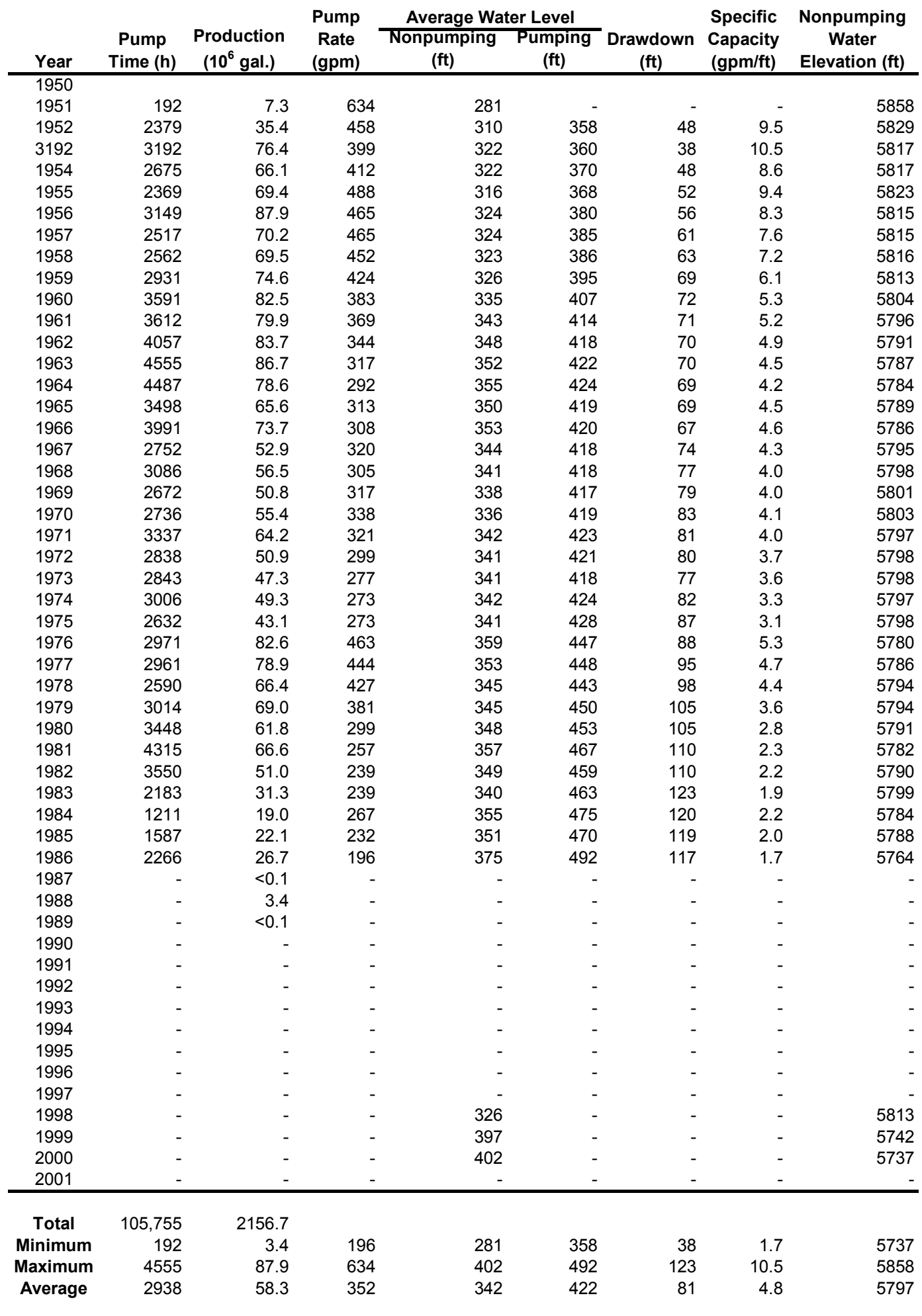

Note: Completed July 1951; initial depth to water $280 \mathrm{ft}$; surface elevation: 6,139 ft; abandoned 1998. 
Well G-4

\begin{tabular}{|c|c|c|c|c|c|c|c|c|}
\hline Year & $\begin{array}{c}\text { Pump } \\
\text { Time (h) }\end{array}$ & $\begin{array}{c}\text { Production } \\
\left(10^{6} \text { gal. }\right)\end{array}$ & $\begin{array}{l}\text { Pump } \\
\text { Rate } \\
\text { (gpm) }\end{array}$ & $\begin{array}{l}\text { Average Wat } \\
\text { Nonpumping } \\
\text { (ft) }\end{array}$ & $\begin{array}{l}\text { er Level } \\
\text { Pumping } \\
\text { (ft) }\end{array}$ & $\begin{array}{c}\text { Drawdown } \\
\text { (ft) }\end{array}$ & $\begin{array}{l}\text { Specific } \\
\text { Capacity } \\
\text { (gpm/ft) }\end{array}$ & $\begin{array}{l}\text { Nonpumping } \\
\text { Water } \\
\text { Elevation (ft) }\end{array}$ \\
\hline 1951 & & 12.5 & - & 357 & 477 & 12 & - & 5872 \\
\hline 1952 & 2401 & 56.9 & 395 & 374 & 474 & 100 & 3.9 & 5855 \\
\hline 1953 & 2677 & 55.2 & 344 & 380 & 472 & 92 & 3.7 & 5849 \\
\hline 1954 & 2256 & 58.8 & 434 & 383 & 526 & 143 & 3.0 & 5846 \\
\hline 1955 & 1172 & 22.7 & 322 & 378 & 481 & 103 & 3.1 & 5851 \\
\hline 1956 & 1800 & 33.9 & 314 & 377 & 491 & 114 & 2.8 & 5852 \\
\hline 1957 & 1324 & 24.2 & 305 & 373 & 498 & 125 & 2.4 & 5856 \\
\hline 1958 & 1970 & 35.9 & 304 & 370 & 490 & 120 & 2.5 & 5859 \\
\hline 1959 & 1819 & 31.6 & 290 & 378 & 494 & 116 & 2.5 & 5851 \\
\hline 1960 & 2457 & 37.0 & 251 & 385 & 509 & 124 & 2.0 & 5844 \\
\hline 1961 & 2787 & 45.0 & 269 & 389 & 512 & 123 & 2.2 & 5840 \\
\hline 1962 & 2738 & 41.7 & 254 & 386 & 505 & 119 & 2.1 & 5843 \\
\hline 1963 & 3519 & 46.4 & 220 & 388 & 504 & 116 & 1.9 & 5841 \\
\hline 1964 & 3561 & 42.9 & 201 & 396 & 499 & 103 & 1.9 & 5833 \\
\hline 1965 & 2100 & 23.8 & 189 & 394 & 492 & 98 & 1.9 & 5835 \\
\hline 1966 & 2219 & 33.6 & 252 & 391 & 498 & 107 & 2.4 & 5838 \\
\hline 1967 & 2690 & 44.8 & 278 & 388 & 509 & 121 & 2.3 & 5841 \\
\hline 1968 & 2083 & 31.4 & 251 & 386 & 509 & 123 & 2.0 & 5843 \\
\hline 1969 & 1309 & 17.4 & 222 & 387 & 505 & 118 & 1.9 & 5842 \\
\hline 1970 & 606 & 7.7 & 212 & 384 & 504 & 114 & 1.9 & 5845 \\
\hline 1971 & 1640 & 21.0 & 213 & 389 & 503 & 114 & 1.9 & 5840 \\
\hline 1972 & 2840 & 33.3 & 195 & 391 & 507 & 116 & 1.7 & 5838 \\
\hline 1973 & 3006 & 37.2 & 206 & 392 & 521 & 129 & 1.6 & 5837 \\
\hline 1974 & 2672 & 34.3 & 214 & 392 & 519 & 127 & 1.7 & 5837 \\
\hline 1975 & 1977 & 41.0 & 346 & 403 & 559 & 156 & 2.2 & 5826 \\
\hline 1976 & 2859 & 57.8 & 337 & 406 & 571 & 165 & 2.0 & 5823 \\
\hline 1977 & 2954 & 62.4 & 352 & 406 & 589 & 183 & 1.9 & 5823 \\
\hline 1978 & 2607 & 49.5 & 317 & 398 & 589 & 191 & 1.7 & 5831 \\
\hline 1979 & 2974 & 52.9 & 296 & 395 & 586 & 191 & 1.6 & 5834 \\
\hline 1980 & 2235 & 35.6 & 266 & 394 & 580 & 186 & 1.4 & 5835 \\
\hline 1981 & 432 & 8.2 & 316 & 385 & 573 & 188 & 1.7 & 5844 \\
\hline 1982 & 3657 & 65.2 & 297 & 386 & 578 & 192 & 1.5 & 5843 \\
\hline 1983 & 2604 & 42.2 & 270 & - & - & - & - & - \\
\hline 1984 & 3766 & 49.7 & 220 & - & - & - & - & - \\
\hline 1985 & 1747 & 21.7 & 207 & 402 & 572 & 170 & 1.2 & 5827 \\
\hline 1986 & 2678 & 33.9 & 211 & 396 & 574 & 178 & 1.2 & 5833 \\
\hline 1987 & 2011 & 25.1 & 208 & 398 & 573 & 175 & 1.2 & 5831 \\
\hline 1988 & 301 & 4.1 & 227 & 390 & 545 & 155 & 1.5 & 5839 \\
\hline 1989 & 1739 & 21.6 & 207 & 401 & 562 & 161 & 1.3 & 5828 \\
\hline 1990 & 1539 & 16.8 & 182 & 381 & 564 & 183 & 1.0 & 5848 \\
\hline 1991 & 1254 & 13.7 & 181 & 382 & 559 & 177 & 1.0 & 5847 \\
\hline 1992 & 1116 & 12.0 & 179 & 387 & 544 & 157 & 1.1 & 5842 \\
\hline 1993 & 0 & 0.0 & - & 374 & - & - & - & 5855 \\
\hline 1994 & 8 & $<0.1$ & 163 & 363 & 525 & 162 & 1.0 & 5866 \\
\hline 1995 & 0 & 0.0 & - & 368 & - & - & 0.0 & 5861 \\
\hline 1996 & 721 & 7.2 & 166 & 374 & 570 & 196 & 0.8 & 5855 \\
\hline 1997 & 518 & 5.4 & 174 & 375 & 560 & 185 & 0.9 & 5854 \\
\hline 1998 & 4 & 0.03 & 170 & 368 & - & - & - & 5861 \\
\hline 1999 & - & - & - & - & - & - & - & - \\
\hline 2000 & - & - & - & - & - & - & - & - \\
\hline 2001 & - & - & - & - & - & - & - & - \\
\hline Total & 91,347 & 1455.2 & & & & & & \\
\hline Minimum & 0 & 0.0 & 163 & 357 & 472 & 12 & 0.0 & 5823 \\
\hline Maximum & 3766 & 65.2 & 434 & 406 & 589 & 196 & 3.9 & 5872 \\
\hline Average & 1944 & 31.0 & 254 & 386 & 530 & 140 & 1.8 & 5843 \\
\hline
\end{tabular}


Well G-5

\begin{tabular}{|c|c|c|c|c|c|c|c|c|}
\hline Year & $\begin{array}{c}\text { Pump } \\
\text { Time (h) }\end{array}$ & $\begin{array}{c}\text { Production } \\
\left(10^{6} \text { gal. }\right)\end{array}$ & $\begin{array}{c}\text { Pump } \\
\text { Rate } \\
\text { (gpm) }\end{array}$ & $\begin{array}{c}\text { Average Wat } \\
\text { Nonpumping } \\
\text { (ft) }\end{array}$ & $\begin{array}{c}\frac{\text { ter Level }}{\text { Pumping }} \\
\text { (ft) }\end{array}$ & $\begin{array}{l}\text { Drawdown } \\
\text { (ft) }\end{array}$ & $\begin{array}{l}\text { Specific } \\
\text { Capacity } \\
\text { (gpm/ft) }\end{array}$ & $\begin{array}{c}\text { Nonpumping } \\
\text { Water } \\
\text { Elevation (ft) }\end{array}$ \\
\hline 1951 & & 6.7 & 1. & 414 & - & - & - & 5892 \\
\hline 1952 & 2579 & 73.8 & 477 & 422 & 480 & 58 & 8.2 & 5884 \\
\hline 1953 & 1433 & 37.8 & 440 & 425 & 467 & 42 & 10.5 & 5881 \\
\hline 1954 & 2617 & 80.9 & 515 & 429 & 473 & 44 & 11.7 & 5877 \\
\hline 1955 & 2529 & 80.4 & 530 & 427 & 472 & 45 & 11.8 & 5879 \\
\hline 1956 & 3052 & 97.0 & 530 & 431 & 478 & 47 & 11.3 & 5875 \\
\hline 1957 & 2385 & 64.1 & 448 & 424 & 466 & 42 & 10.7 & 5882 \\
\hline 1958 & 1523 & 49.1 & 537 & 428 & 477 & 49 & 11.0 & 5878 \\
\hline 1959 & 2917 & 101.7 & 581 & 435 & 495 & 60 & 9.7 & 5871 \\
\hline 1960 & 2828 & 98.0 & 578 & 437 & 501 & 64 & 9.0 & 5869 \\
\hline 1961 & 3908 & 134.0 & 572 & 438 & 507 & 69 & 8.3 & 5868 \\
\hline 1962 & 4186 & 142.0 & 565 & 440 & 511 & 71 & 8.0 & 5866 \\
\hline 1963 & 4528 & 151.0 & 556 & 441 & 513 & 72 & 7.7 & 5865 \\
\hline 1964 & 4352 & 150.4 & 553 & 446 & 516 & 70 & 7.9 & 5860 \\
\hline 1965 & 3520 & 117.1 & 555 & 443 & 516 & 73 & 7.6 & 5863 \\
\hline 1966 & 2555 & 83.2 & 543 & 445 & 520 & 75 & 7.2 & 5861 \\
\hline 1967 & 2405 & 80.0 & 554 & 444 & 519 & 75 & 7.4 & 5862 \\
\hline 1968 & 2513 & 81.2 & 539 & 443 & 517 & 74 & 7.3 & 5863 \\
\hline 1969 & 2649 & 83.3 & 524 & 450 & 520 & 70 & 7.5 & 5856 \\
\hline 1970 & 2771 & 88.9 & 535 & 453 & 521 & 68 & 7.9 & 5853 \\
\hline 1971 & 2657 & 88.3 & 554 & 450 & 521 & 71 & 7.8 & 5856 \\
\hline 1972 & 2902 & 92.4 & 531 & 441 & 514 & 73 & 7.3 & 5865 \\
\hline 1973 & 3003 & 97.5 & 541 & 444 & 515 & 71 & 7.6 & 5862 \\
\hline 1974 & 2054 & 69.0 & 560 & 440 & 513 & 73 & 7.7 & 5866 \\
\hline 1975 & 2266 & 74.7 & 549 & 433 & 500 & 67 & 8.2 & 5873 \\
\hline 1976 & 2955 & 95.0 & 536 & 442 & 504 & 62 & 8.6 & 5864 \\
\hline 1977 & 2836 & 92.1 & 541 & 444 & 504 & 60 & 9.0 & 5862 \\
\hline 1978 & 2608 & 84.2 & 538 & 442 & 502 & 60 & 9.0 & 5864 \\
\hline 1979 & 2766 & 86.5 & 522 & 442 & 502 & 60 & 8.7 & 5864 \\
\hline 1980 & 2896 & 89.0 & 512 & 442 & 502 & 60 & 8.5 & 5864 \\
\hline 1981 & 2124 & 66.7 & 523 & 451 & 528 & 77 & 6.8 & 5855 \\
\hline 1982 & 1219 & 38.2 & 522 & 455 & 510 & 55 & 9.5 & 5851 \\
\hline 1983 & 2904 & 73.2 & 420 & 445 & 492 & 47 & 8.9 & 5861 \\
\hline 1984 & 3838 & 115.4 & 501 & 452 & 507 & 55 & 9.1 & 5854 \\
\hline 1985 & 2193 & 67.9 & 516 & 453 & 509 & 56 & 9.2 & 5853 \\
\hline 1986 & 2219 & 52.5 & 394 & 453 & 494 & 41 & 9.6 & 5853 \\
\hline 1987 & 5732 & 116.7 & 379 & 462 & 504 & 42 & 9.0 & 5844 \\
\hline 1988 & 4841 & 115.3 & 396 & 466 & 507 & 41 & 9.7 & 5840 \\
\hline 1989 & 4715 & 110.9 & 392 & 474 & 514 & 40 & 9.8 & 5832 \\
\hline 1990 & 5094 & 119.2 & 390 & 485 & 526 & 41 & 9.5 & 5821 \\
\hline 1991 & 4981 & 113.0 & 378 & 487 & 534 & 47 & 8.0 & 5819 \\
\hline 1992 & 5006 & 114.4 & 376 & 470 & 508 & 38 & 9.9 & 5836 \\
\hline 1993 & 3859 & 92.2 & 398 & 466 & 503 & 37 & 10.8 & 5840 \\
\hline 1994 & 109 & 2.5 & 388 & 459 & 494 & 35 & 11.1 & 5847 \\
\hline 1995 & 807 & 17.6 & 364 & - & - & - & - & - \\
\hline 1996 & 2686 & 66.9 & 415 & - & - & - & - & - \\
\hline 1997 & 3238 & 81.5 & 419 & - & - & - & - & - \\
\hline 1998 & 413 & 6.5 & 374 & - & - & - & - & - \\
\hline 1999 & - & - & - & - & - & - & - & - \\
\hline 2000 & - & - & - & - & - & - & - & - \\
\hline 2001 & - & - & - & - & - & - & - & - \\
\hline Total & 138,171 & 4039.9 & & & & & & \\
\hline Minimum & 109 & 2.5 & 364 & 414 & 466 & 35 & 6.8 & 5819 \\
\hline Maximum & 5732 & 151 & 581 & 487 & 534 & 77 & 11.8 & 5892 \\
\hline Average & 2940 & 84.2 & 491 & 446 & 504 & 58 & 8.9 & 5860 \\
\hline
\end{tabular}

Note: Well completed May 1951; initial depth to water: $411 \mathrm{ft}$; surface elevation: 6,306 ft; plugged Sept. 1999 
Well G-6

\begin{tabular}{|c|c|c|c|c|c|c|c|c|}
\hline Year & $\begin{array}{c}\text { Pump } \\
\text { Time (h) }\end{array}$ & $\begin{array}{c}\text { Production } \\
\left(10^{6} \text { gal. }\right)\end{array}$ & $\begin{array}{l}\text { Pump } \\
\text { Rate } \\
\text { (gpm) }\end{array}$ & $\begin{array}{c}\text { Average Wa } \\
\text { Nonpumping } \\
\text { (ft) }\end{array}$ & $\begin{array}{c}\text { ter Level } \\
\text { Pumping } \\
\text { (ft) }\end{array}$ & $\begin{array}{l}\text { Drawdown } \\
\text { (ft) }\end{array}$ & $\begin{array}{c}\text { Specific } \\
\text { Capacity } \\
\text { (gpm/ft) }\end{array}$ & $\begin{array}{l}\text { Nonpumping } \\
\text { Water } \\
\text { Elevation (ft) }\end{array}$ \\
\hline 1964 & 1912 & 45.0 & 392 & 581 & 659 & 78 & 5.0 & 5841 \\
\hline 1965 & 3200 & 74.9 & 390 & 582 & 660 & 78 & 5.0 & 5840 \\
\hline 1966 & 3931 & 92.2 & 391 & 585 & 658 & 73 & 5.4 & 5837 \\
\hline 1967 & 5454 & 57.8 & 393 & 580 & 653 & 73 & 5.4 & 5842 \\
\hline 1968 & 2597 & 56.2 & 361 & 574 & 647 & 73 & 4.9 & 5848 \\
\hline 1969 & 2698 & 55.6 & 344 & 568 & 636 & 68 & 5.1 & 5854 \\
\hline 1970 & 2765 & 51.0 & 307 & 569 & 634 & 65 & 4.7 & 5853 \\
\hline 1971 & 2932 & 42.8 & 243 & 573 & 629 & 56 & 4.3 & 5849 \\
\hline 1972 & 2516 & 57.0 & 378 & 578 & 670 & 92 & 4.1 & 5844 \\
\hline 1973 & 2991 & 65.3 & 364 & 579 & 667 & 88 & 4.1 & 5843 \\
\hline 1974 & 2950 & 63.8 & 361 & 579 & 665 & 86 & 4.2 & 5843 \\
\hline 1975 & 2717 & 56.7 & 348 & 577 & 659 & 82 & 4.2 & 5845 \\
\hline 1976 & 2966 & 57.8 & 325 & 584 & 662 & 78 & 4.2 & 5838 \\
\hline 1977 & 2954 & 54.4 & 307 & 586 & 659 & 73 & 4.2 & 5836 \\
\hline 1978 & 2218 & 384.0 & 289 & 581 & 645 & 64 & 4.5 & 5841 \\
\hline 1979 & 1030 & 18.2 & 295 & 579 & 645 & 66 & 4.5 & 5843 \\
\hline 1980 & 1789 & 34.5 & 322 & 583 & 670 & 87 & 3.7 & 5839 \\
\hline 1981 & 4302 & 76.5 & 296 & 586 & 673 & 87 & 3.4 & 5836 \\
\hline 1982 & 3763 & 63.6 & 281 & 588 & 669 & 81 & 3.5 & 5834 \\
\hline 1983 & 1960 & 35.4 & 301 & 582 & 668 & 86 & 3.5 & 5840 \\
\hline 1984 & 3010 & 55.3 & 306 & 589 & 666 & 77 & 4.0 & 5833 \\
\hline 1985 & 3980 & 71.4 & 299 & 586 & 664 & 78 & 3.8 & 5836 \\
\hline 1986 & 4420 & 76.7 & 293 & 576 & 654 & 78 & 3.8 & 5846 \\
\hline 1987 & 5100 & 81.4 & 266 & 595 & 671 & 76 & 3.5 & 5827 \\
\hline 1988 & 5121 & 82.1 & 267 & 591 & 669 & 78 & 3.4 & 5831 \\
\hline 1989 & 5000 & 81.6 & 272 & 592 & 669 & 77 & 3.5 & 5830 \\
\hline 1990 & 5202 & 44.9 & 272 & 589 & 670 & 81 & 3.4 & 5833 \\
\hline 1991 & 5063 & 81.2 & 267 & 591 & 674 & 83 & 3.2 & 5831 \\
\hline 1992 & 4382 & 70.2 & 268 & 591 & 673 & 80 & 3.4 & 5831 \\
\hline 1993 & - & - & - & 575 & - & - & - & 5847 \\
\hline 1994 & 1660 & 27.5 & 276 & 572 & 652 & 80 & 3.5 & 5850 \\
\hline 1995 & 2892 & 46.4 & 267 & 577 & 660 & 83 & 3.2 & 5845 \\
\hline 1996 & 2311 & 36.0 & 260 & 581 & 661 & 80 & 3.2 & 5841 \\
\hline 1997 & 1262 & 19.5 & 258 & 581 & 658 & 77 & 3.3 & 5841 \\
\hline 1998 & 3311 & 46.8 & 243 & 583 & 666 & 83 & 2.9 & 5839 \\
\hline 1999 & 867 & 12.9 & 247 & - & - & - & - & - \\
\hline 2000 & - & - & - & - & - & - & - & - \\
\hline 2001 & - & - & - & - & - & - & - & - \\
\hline Total & 111,226 & 2276.6 & & & & & & \\
\hline Minimum & 867 & 12.9 & 243 & 568 & 629 & 56 & 2.9 & 5827 \\
\hline Maximum & 5454 & 384.0 & 393 & 595 & 674 & 92 & 5.4 & 5854 \\
\hline Average & 3178 & 65.0 & 307 & 582 & 660 & 78 & 4.0 & 5840 \\
\hline
\end{tabular}

Note: Well completed Mar. 1964; initial depth to water: 572 ft; surface elevation: 6,422 ft; plugged Sept. 1999. 
Well G-2A

\begin{tabular}{|c|c|c|c|c|c|c|c|c|}
\hline \multirow[b]{2}{*}{ Year } & \multirow[b]{2}{*}{$\begin{array}{l}\text { Pump } \\
\text { Time (h) }\end{array}$} & \multirow[b]{2}{*}{$\begin{array}{c}\text { Production } \\
\left(10^{6} \text { gal. }\right)\end{array}$} & \multirow{2}{*}{$\begin{array}{l}\text { Pump } \\
\text { Rate } \\
\text { (gpm) }\end{array}$} & \multicolumn{2}{|c|}{ Average Water Level } & \multirow[b]{2}{*}{$\begin{array}{c}\text { Drawdown } \\
\text { (ft) }\end{array}$} & \multirow{2}{*}{$\begin{array}{l}\text { Specific } \\
\text { Capacity } \\
\text { (gpm/ft) }\end{array}$} & \multirow{2}{*}{$\begin{array}{l}\text { Nonpumping } \\
\text { Water } \\
\text { Elevation (ft) }\end{array}$} \\
\hline & & & & $\begin{array}{l}\text { Nonpumping } \\
\text { (ft) }\end{array}$ & $\begin{array}{l}\text { Pumping } \\
\text { (ft) }\end{array}$ & & & \\
\hline 1998 & & & 900 & 318.4 & 429.7 & 111.3 & 8.1 & 5821.6 \\
\hline 1999 & 1708 & 82.0 & 800 & 390.6 & 428.9 & 38.3 & 20.9 & 5749.4 \\
\hline 2000 & 3904 & 178.0 & 760 & 407.2 & 463.4 & 56.2 & 13.5 & 5732.8 \\
\hline 2001 & 3012 & 148.2 & 820 & 389.3 & 443.8 & 54.5 & 15.0 & 5750.7 \\
\hline Total & 8623 & 408.2 & & & & & & \\
\hline Minimum & 1708 & 82.0 & 760 & 318.4 & 428.9 & 38.3 & 8.1 & 5732.8 \\
\hline Maximum & 3904 & 178.0 & 900 & 407.2 & 463.4 & 111.3 & 20.9 & 5821.6 \\
\hline Average & 2874 & 136.1 & 820 & 376.4 & 441.5 & 65.1 & 14.4 & 5763.6 \\
\hline
\end{tabular}

Note: Well completed March 1998, initial depth to water: $318.4 \mathrm{ft}$; surface elevation: $6,140 \mathrm{ft}$

Well G-3A

\begin{tabular}{|c|c|c|c|c|c|c|c|c|}
\hline Year & $\begin{array}{c}\text { Pump } \\
\text { Time (h) }\end{array}$ & $\begin{array}{c}\text { Production } \\
\left(10^{6} \text { gal. }\right)\end{array}$ & $\begin{array}{l}\text { Pump } \\
\text { Rate } \\
\text { (gpm) }\end{array}$ & $\begin{array}{c}\text { Average Wat } \\
\begin{array}{c}\text { Nonpumping } \\
\text { (ft) }\end{array}\end{array}$ & $\begin{array}{c}\text { ter Level } \\
\qquad \begin{array}{c}\text { Pumping } \\
\text { (ft) }\end{array}\end{array}$ & $\begin{array}{l}\text { Drawdown } \\
\text { (ft) }\end{array}$ & $\begin{array}{l}\text { Specific } \\
\text { Capacity } \\
\text { (gpm/ft) }\end{array}$ & $\begin{array}{c}\text { Nonpumping } \\
\text { Water Elevation } \\
\text { (ft) }\end{array}$ \\
\hline 1998 & & & 800 & 396.8 & 518.3 & 121.5 & 6.6 & 5815.2 \\
\hline 1999 & 1036 & 40.8 & 656 & 415.3 & 428.0 & 12.7 & 51.7 & 5796.7 \\
\hline 2000 & 2955 & 102.8 & 580 & 451.0 & 501.5 & 50.5 & 11.5 & 5761.0 \\
\hline 2001 & 717 & 28.0 & 650 & 507.5 & 526.1 & 18.6 & 34.9 & 5704.5 \\
\hline Total & 4709 & 171.6 & & & & & & \\
\hline Minimum & 717 & 28.0 & 580 & 396.8 & 428.0 & 12.7 & 6.6 & 5704.5 \\
\hline Maximum & 2955 & 102.8 & 800 & 507.5 & 526.1 & 121.5 & 51.7 & 5815.2 \\
\hline Average & 1570 & 57.2 & 672 & 442.7 & 493.5 & 50.8 & 26.2 & 5769.4 \\
\hline
\end{tabular}

Note: Well completed May 1998, initial depth to water: $396.8 \mathrm{ft}$; surface elevatioin: 6,212 ft.

Well G-4A

\begin{tabular}{|c|c|c|c|c|c|c|c|c|}
\hline Year & $\begin{array}{c}\text { Pump } \\
\text { Time (h) }\end{array}$ & $\begin{array}{c}\text { Production } \\
\text { (10 }{ }^{6} \text { gal.) }\end{array}$ & $\begin{array}{l}\text { Pump } \\
\text { Rate } \\
\text { (gpm) }\end{array}$ & $\begin{array}{c}\text { Average Wat } \\
\text { Nonpumping } \\
\text { (ft) }\end{array}$ & $\begin{array}{l}\text { er Level } \\
\text { Pumping } \\
\text { (ft) }\end{array}$ & $\begin{array}{c}\text { Drawdown } \\
\text { (ft) }\end{array}$ & $\begin{array}{l}\text { Specific } \\
\text { Capacity } \\
\text { (gpm/ft) }\end{array}$ & $\begin{array}{l}\text { Nonpumping } \\
\text { Water } \\
\text { Elevation (ft) }\end{array}$ \\
\hline 1998 & & & 780 & 451.7 & 590.3 & 138.6 & 5.6 & 5847.3 \\
\hline 1999 & 1746 & 61.2 & 584 & 478.7 & 565.7 & 87.0 & 6.7 & 5820.3 \\
\hline 2000 & 1959 & 61.7 & 525 & 500.1 & 575.5 & 75.4 & 7.0 & 5798.9 \\
\hline 2001 & 206 & 6.5 & 525 & 515.0 & 557.0 & 42.0 & 12.5 & 5784.0 \\
\hline Total & 3910 & 129.4 & & & & & & \\
\hline Minimum & 206 & 6.5 & 525 & 451.7 & 557.0 & 42.0 & 5.6 & 5784.0 \\
\hline Maximum & 1959 & 61.7 & 780 & 515.0 & 590.3 & 138.6 & 12.5 & 5847.3 \\
\hline Average & 1303 & 43.1 & 604 & 486.4 & 572.1 & 85.8 & 8.0 & 5812.6 \\
\hline
\end{tabular}

Note: Well Completed April 1998; initial depth to water: $451.7 \mathrm{ft}$; surface elevation: $6299 \mathrm{ft}$. 
Well G-5A

\begin{tabular}{|c|c|c|c|c|c|c|c|c|}
\hline Year & $\begin{array}{c}\text { Pump } \\
\text { Time (h) }\end{array}$ & $\begin{array}{c}\text { Production } \\
\left(10^{6} \text { gal. }\right)\end{array}$ & $\begin{array}{l}\text { Pump } \\
\text { Rate } \\
\text { (gpm) }\end{array}$ & $\begin{array}{c}\text { Average Wat } \\
\text { Nonpumping } \\
\text { (ft) }\end{array}$ & $\begin{array}{l}\text { er Level } \\
\text { Pumping } \\
\text { (ft) }\end{array}$ & $\begin{array}{c}\text { Drawdown } \\
\text { (ft) }\end{array}$ & $\begin{array}{l}\text { Specific } \\
\text { Capacity } \\
\text { (gpm/ft) }\end{array}$ & $\begin{array}{l}\text { Nonpumping } \\
\text { Water } \\
\text { Elevation (ft) }\end{array}$ \\
\hline 1998 & & & 400 & 550.7 & 702.9 & 152.2 & 2.6 & 5863.3 \\
\hline 1999 & 9.4 & 0.23 & 400 & - & - & - & - & - \\
\hline 2000 & 64.8 & 1.6 & 400 & 558.4 & 684.8 & 126.4 & 3.2 & 5855.6 \\
\hline 2001 & 9.3 & 0.21 & 375 & 565.6 & 599.0 & 33.4 & 11.2 & 5848.4 \\
\hline Total & 83.5 & 2.0 & & & & & & \\
\hline Minimum & 9 & 0.2 & 375 & 550.7 & 599.0 & 33.4 & 2.6 & 5848.4 \\
\hline Maximum & 65 & 1.6 & 400 & 565.6 & 702.9 & 152.2 & 11.2 & 5863.3 \\
\hline Average & 28 & 0.7 & 394 & 558.2 & 662.2 & 104.0 & 5.7 & 5855.8 \\
\hline
\end{tabular}

Note: Well Completed June 1998; initial depth to water: $550.7 \mathrm{ft}$; surface elevation: 6,414 ft.

Well 0-1

\begin{tabular}{|c|c|c|c|c|c|c|c|c|}
\hline Year & $\begin{array}{c}\text { Pump } \\
\text { Time (h) }\end{array}$ & $\begin{array}{c}\text { Production } \\
\text { (10 }{ }^{6} \text { gal.) }\end{array}$ & $\begin{array}{l}\text { Pump } \\
\text { Rate } \\
\text { (gpm) }\end{array}$ & $\begin{array}{c}\text { Average Wat } \\
\text { Nonpumping } \\
\text { (ft) }\end{array}$ & $\begin{array}{l}\text { er Level } \\
\text { Pumping } \\
\text { (ft) }\end{array}$ & $\begin{array}{c}\text { Drawdown } \\
\text { (ft) }\end{array}$ & $\begin{array}{l}\text { Specific } \\
\text { Capacity } \\
\text { (gpm/ft) }\end{array}$ & $\begin{array}{l}\text { Nonpumping } \\
\quad \text { Water } \\
\text { Elevation (ft) }\end{array}$ \\
\hline 1990 & & & & 675 & & & & 5721 \\
\hline 1991 & & & & & & & & \\
\hline 1992 & & & & & & & & \\
\hline 1993 & & & & & & & & \\
\hline 1994 & & & & & & & & \\
\hline 1995 & - & - & - & 675 & - & - & - & 5721 \\
\hline 1996 & - & - & - & 675 & - & - & - & 5721 \\
\hline 1997 & - & - & - & 676 & - & - & - & 5720 \\
\hline 1998 & 1252 & 67.1 & 918 & - & - & - & - & - \\
\hline 1999 & 222 & 13.0 & 973 & 701.9 & 802.2 & 100.3 & 9.7 & 5694 \\
\hline 2000 & 914 & 53.3 & 973 & 695.4 & 829.2 & 133.8 & 7.3 & 5701 \\
\hline 2001 & 431 & 25.2 & 973 & 686.3 & 827.6 & 141.3 & 6.9 & 5710 \\
\hline Total & 2819 & 158.6 & & & & & & \\
\hline Minimum & 222 & 13.0 & 918 & 675.0 & 802.2 & 100.3 & 6.9 & 5694 \\
\hline Maximum & 1252 & 67.1 & 973 & 701.9 & 829.2 & 141.3 & 9.7 & 5721 \\
\hline Average & 705 & 39.7 & 959 & 683.5 & 819.7 & 125.1 & 8.0 & 5712 \\
\hline
\end{tabular}

Note: Well completed August 1990; initial depth to water: $675 \mathrm{ft}$; surface elevation 6,396 ft. 


\section{Well 0-4}

\begin{tabular}{|c|c|c|c|c|c|c|c|c|}
\hline Year & $\begin{array}{c}\text { Pump } \\
\text { Time (h) }\end{array}$ & $\begin{array}{c}\text { Production } \\
\left.\text { (10 }{ }^{6} \text { gal. }\right)\end{array}$ & $\begin{array}{l}\text { Pump } \\
\text { Rate } \\
\text { (gpm) }\end{array}$ & $\begin{array}{c}\text { Average Wa } \\
\text { Nonpumping } \\
\text { (ft) }\end{array}$ & $\begin{array}{c}\text { ter Level } \\
\text { Pumping } \\
\text { (ft) }\end{array}$ & $\begin{array}{c}\text { Drawdown } \\
\text { (ft) }\end{array}$ & $\begin{array}{l}\text { Specific } \\
\text { Capacity } \\
\text { (gpm/ft) }\end{array}$ & $\begin{array}{l}\text { Nonpumping } \\
\quad \text { Water } \\
\text { Elevation (ft) }\end{array}$ \\
\hline 1990 & & & & 780 & & & & 5847 \\
\hline 1991 & & & & & & & & \\
\hline 1992 & & & & & & & & \\
\hline 1993 & 2942 & 283.8 & 1603 & 761 & 789 & 28 & 57.3 & 5866 \\
\hline 1994 & 2456 & 205.7 & 1396 & 760 & 781 & 21 & 66.5 & 5867 \\
\hline 1995 & 0 & 0.0 & - & 762 & - & - & - & 5865 \\
\hline 1996 & 2330 & 209.6 & 1499 & - & - & - & - & - \\
\hline 1997 & 2396 & 216.4 & 1505 & - & - & - & - & - \\
\hline 1998 & 2723 & 239.7 & 1471 & - & - & - & - & - \\
\hline 1999 & 2260 & 200.5 & 1479 & - & - & - & - & - \\
\hline 2000 & 1368 & 119.0 & 1450 & - & - & - & - & - \\
\hline 2001 & 4177 & 363.4 & 1450 & - & - & - & - & - \\
\hline Total & 20,651 & 1838.1 & & & & & & \\
\hline Minimum & 1368 & 119.0 & 1396 & 760.0 & 781.0 & 21.0 & 57.3 & 5847 \\
\hline Maximum & 4177 & 363.4 & 1603 & 780.0 & 789.0 & 28.0 & 66.5 & 5867 \\
\hline Average & 2581 & 229.8 & 1482 & 765.8 & 785.0 & 24.5 & 61.9 & 5861 \\
\hline
\end{tabular}

Note: Well completed Mar. 1990; initial depth to water: $780 \mathrm{ft}$; surface elevation 6,627 ft. 
Well PM-1

\begin{tabular}{|c|c|c|c|c|c|c|c|c|}
\hline Year & $\begin{array}{c}\text { Pump } \\
\text { Time (h) }\end{array}$ & $\begin{array}{c}\text { Production } \\
\left(10^{6} \text { gal. }\right)\end{array}$ & $\begin{array}{l}\text { Pump } \\
\text { Rate } \\
\text { (gpm) }\end{array}$ & $\begin{array}{c}\text { Average Wa } \\
\text { Nonpumping } \\
\text { (ft) }\end{array}$ & $\begin{array}{c}\text { ter Level } \\
\text { Pumping } \\
\text { (ft) }\end{array}$ & $\begin{array}{c}\text { Drawdown } \\
\text { (ft) }\end{array}$ & $\begin{array}{c}\text { Specific } \\
\text { Capacity } \\
\text { (gpm/ft) }\end{array}$ & $\begin{array}{l}\text { Nonpumping } \\
\text { Water } \\
\text { Elevation (ft) }\end{array}$ \\
\hline 1965 & 2754 & 99.2 & 600 & 746 & 786 & 40 & 15.0 & 5774 \\
\hline 1966 & 3086 & 108.0 & 583 & 740 & 779 & 39 & 15.0 & 5780 \\
\hline 1967 & 2870 & 111.0 & 644 & 737 & 781 & 44 & 14.6 & 5783 \\
\hline 1968 & 1846 & 68.1 & 615 & 735 & 769 & 34 & 18.1 & 5785 \\
\hline 1969 & 951 & 34.4 & 603 & 733 & 766 & 33 & 18.3 & 5787 \\
\hline 1970 & 1781 & 66.2 & 620 & 733 & 769 & 36 & 17.2 & 5787 \\
\hline 1971 & 2728 & 101.0 & 617 & 733 & 766 & 33 & 18.7 & 5787 \\
\hline 1972 & 2415 & 84.9 & 586 & 735 & 762 & 27 & 21.7 & 5785 \\
\hline 1973 & 1688 & 46.5 & 459 & 736 & 755 & 19 & 24.2 & 5784 \\
\hline 1974 & 2649 & 96.3 & 606 & 740 & 768 & 28 & 21.6 & 5780 \\
\hline 1975 & 2567 & 94.8 & 616 & 741 & 766 & 25 & 24.6 & 5779 \\
\hline 1976 & 2933 & 106.8 & 607 & 744 & 767 & 23 & 26.4 & 5776 \\
\hline 1977 & 2969 & 105.4 & 592 & 745 & 767 & 22 & 26.9 & 5775 \\
\hline 1978 & 2544 & 90.6 & 593 & 745 & 767 & 22 & 27.0 & 5775 \\
\hline 1979 & 2350 & 83.4 & 592 & 744 & 766 & 22 & 26.9 & 5776 \\
\hline 1980 & 2786 & 98.5 & 589 & 746 & 769 & 23 & 25.6 & 5774 \\
\hline 1981 & 2789 & 98.5 & 589 & 747 & 769 & 22 & 26.8 & 5773 \\
\hline 1982 & 2820 & 99.6 & 589 & 748 & 770 & 22 & 26.8 & 5772 \\
\hline 1983 & 2464 & 86.5 & 585 & 747 & 769 & 22 & 26.6 & 5773 \\
\hline 1984 & 2667 & 92.8 & 580 & 749 & 772 & 23 & 25.2 & 5771 \\
\hline 1985 & 2760 & 95.4 & 576 & 749 & 770 & 21 & 27.4 & 5771 \\
\hline 1986 & 2130 & 73.9 & 578 & 748 & 770 & 22 & 26.3 & 5772 \\
\hline 1987 & 2912 & 102.4 & 586 & 752 & 773 & 21 & 27.9 & 5768 \\
\hline 1988 & 2758 & 98.0 & 592 & 751 & 775 & 24 & 24.7 & 5769 \\
\hline 1989 & 3014 & 104.9 & 580 & 752 & 774 & 22 & 26.4 & 5768 \\
\hline 1990 & 2620 & 88.2 & 561 & 752 & 772 & 20 & 28.1 & 5768 \\
\hline 1991 & 2600 & 88.6 & 568 & 752 & 774 & 22 & 25.8 & 5768 \\
\hline 1992 & 2503 & 92.7 & 617 & 756 & 780 & 24 & 25.7 & 5764 \\
\hline 1993 & 1802 & 63.9 & 591 & 758 & 779 & 21 & 28.1 & 5762 \\
\hline 1994 & 1254 & 43.4 & 577 & 755 & 778 & 23 & 25.1 & 5765 \\
\hline 1995 & 870 & 29.7 & 569 & 753 & 776 & 23 & 24.7 & 5767 \\
\hline 1996 & 1084 & 36.3 & 560 & 755 & 778 & 23 & 24.3 & 5765 \\
\hline 1997 & 1406 & 47.7 & 560 & 760 & 784 & 24 & 23.3 & 5760 \\
\hline 1998 & 1087 & 34.3 & 574 & 760 & 786 & 27 & 21.3 & 5761 \\
\hline 1999 & 1629 & 57.3 & 586 & - & - & - & - & - \\
\hline 2000 & 3032 & 106.6 & 586 & - & - & - & - & - \\
\hline 2001 & 1895 & 66.6 & 586 & - & - & - & - & - \\
\hline Total & 85,012 & 3002.4 & & & & & & \\
\hline Minimum & 870 & 29.7 & 459 & 733 & 755 & 19 & 14.6 & 5760 \\
\hline Maximum & 3086 & 111.0 & 644 & 760 & 786 & 44 & 28.1 & 5787 \\
\hline Average & 2298 & 81.1 & 587 & 746 & 772 & 26 & 23.7 & 5774 \\
\hline
\end{tabular}

Note: Well completed Mar. 1965; initial depth to water: $722.1 \mathrm{ft}$; surface elevation 6,520 ft. 
Well PM-2

\begin{tabular}{|c|c|c|c|c|c|c|c|c|}
\hline Year & $\begin{array}{c}\text { Pump } \\
\text { Time (h) }\end{array}$ & $\begin{array}{c}\text { Production } \\
\left(10^{6} \text { gal. }\right)\end{array}$ & $\begin{array}{c}\text { Pump } \\
\text { Rate } \\
\text { (gpm) }\end{array}$ & $\begin{array}{c}\text { Average Wat } \\
\text { Nonpumping } \\
\text { (ft) }\end{array}$ & $\begin{array}{c}\text { ter Level } \\
\text { Pumping } \\
\text { (ft) }\end{array}$ & $\begin{array}{c}\text { Drawdown } \\
\text { (ft) }\end{array}$ & $\begin{array}{c}\text { Specific } \\
\text { Capacity } \\
\text { (gpm/ft) }\end{array}$ & $\begin{array}{c}\text { Nonpumping } \\
\text { Water } \\
\text { Elevation (ft) }\end{array}$ \\
\hline 1965 & & & & 823 & & & & \\
\hline 1966 & 221 & 18.9 & 1425 & 826 & 889 & 63 & 22.6 & 5889 \\
\hline 1967 & 4336 & 370.0 & 1422 & 834 & 888 & 54 & 26.3 & 5881 \\
\hline 1968 & 3865 & 328.2 & 1415 & 838 & 889 & 51 & 27.8 & 5877 \\
\hline 1969 & 3304 & 279.9 & 1412 & 838 & 890 & 52 & 27.2 & 5877 \\
\hline 1970 & 3529 & 300.6 & 1420 & 839 & 893 & 54 & 26.3 & 5876 \\
\hline 1971 & 4035 & 339.5 & 1402 & 841 & 898 & 57 & 24.6 & 5874 \\
\hline 1972 & 4611 & 385.3 & 1393 & 845 & 902 & 57 & 24.4 & 5870 \\
\hline 1973 & 4571 & 380.6 & 1388 & 849 & 907 & 58 & 23.9 & 5866 \\
\hline 1974 & 5443 & 450.9 & 1381 & 853 & 912 & 59 & 23.4 & 5862 \\
\hline 1975 & 4644 & 385.3 & 1383 & 854 & 913 & 59 & 23.4 & 5861 \\
\hline 1976 & 5382 & 442.0 & 1369 & 866 & 924 & 58 & 23.6 & 5849 \\
\hline 1977 & 3306 & 272.8 & 1375 & 868 & 924 & 56 & 24.6 & 5847 \\
\hline 1978 & 4743 & 388.4 & 1365 & 871 & 928 & 57 & 23.9 & 5844 \\
\hline 1979 & 4671 & 381.8 & 1262 & 872 & 924 & 52 & 24.3 & 5843 \\
\hline 1980 & 5023 & 409.6 & 1359 & 873 & 931 & 58 & 23.4 & 5842 \\
\hline 1981 & 4551 & 370.1 & 1355 & 876 & 934 & 58 & 23.4 & 5839 \\
\hline 1982 & 4319 & 359.3 & 1386 & 874 & 934 & 60 & 23.1 & 5841 \\
\hline 1983 & 1922 & 157.9 & 1369 & 876 & 935 & 59 & 23.2 & 5839 \\
\hline 1984 & 996 & 81.6 & 1365 & 866 & 930 & 64 & 21.3 & 5849 \\
\hline 1985 & 1749 & 143.3 & 1365 & 851 & 916 & 65 & 21.0 & 5864 \\
\hline 1986 & 1036 & 84.4 & 1359 & 851 & 915 & 64 & 21.2 & 5864 \\
\hline 1987 & 351 & 28.3 & 1340 & 851 & 907 & 56 & 23.9 & 5864 \\
\hline 1988 & 1843 & 146.8 & 1328 & 869 & 931 & 62 & 21.4 & 5846 \\
\hline 1989 & 1639 & 130.0 & 1322 & 860 & 920 & 60 & 22.0 & 5855 \\
\hline 1990 & 3164 & 250.4 & 1319 & 860 & 928 & 68 & 19.4 & 5855 \\
\hline 1991 & 2141 & 170.7 & 1329 & 855 & 918 & 63 & 21.1 & 5860 \\
\hline 1992 & 3486 & 277.7 & 1328 & 860 & 929 & 69 & 19.2 & 5855 \\
\hline 1993 & 3420 & 267.8 & 1305 & 855 & 924 & 69 & 18.9 & 5860 \\
\hline 1994 & 3922 & 298.9 & 1270 & 870 & 934 & 64 & 19.8 & 5845 \\
\hline 1995 & 2778 & 217.7 & 1306 & 870 & 934 & 64 & 20.4 & 5845 \\
\hline 4023 & 4023 & 302.2 & 1250 & - & - & - & - & - \\
\hline 1997 & 2154 & 162.9 & 1260 & - & - & - & - & - \\
\hline 1998 & 4835 & 386.2 & 1243 & 839 & 912 & 73 & 17.0 & 5876 \\
\hline 1999 & 3257 & 249.2 & 1275 & - & - & - & - & - \\
\hline 2000 & 4365 & 333.9 & 1275 & 852 & 919 & 67 & 19.0 & 5863 \\
\hline 2001 & 3965 & 303.3 & 1275 & 855 & 920 & 64 & 19.8 & 5860 \\
\hline Total & 121,600 & 9856.4 & & & & & & \\
\hline Minimum & 221 & 18.9 & 1243 & 826 & 888 & 51 & 17.0 & 5839 \\
\hline Maximum & 5443 & 450.9 & 1425 & 876 & 935 & 73 & 27.8 & 5889 \\
\hline Average & 3378 & 273.8 & 1344 & 856 & 917 & 60 & 22.6 & 5859 \\
\hline
\end{tabular}

Note: Well completed July 1965; initial depth to water: $823 \mathrm{ft}$; surface elevation $6715 \mathrm{ft}$. 
Well PM-3

Pump Average Water Level

Specific Nonpumping Pump Production Rate Nonpumping Pumping Drawdown Capacity Water

\begin{tabular}{|c|c|c|c|c|c|c|c|c|}
\hline Year & Time (h) & (10 $0^{6}$ gal.) & (gpm) & (ft) & (ft) & (ft) & (gpm/ft) & Elevation (ft) \\
\hline 1965 & & & & & & & & \\
\hline 1966 & & & & 740 & & & & \\
\hline 1967 & & & & & & & & \\
\hline 1968 & 2327 & 187.4 & 1342 & 743 & 771 & 28 & 47.9 & 5897 \\
\hline 1969 & 3241 & 254.7 & 1310 & 746 & 772 & 26 & 50.4 & 5894 \\
\hline 1970 & 2905 & 227.8 & 1307 & 750 & 774 & 24 & 54.5 & 5890 \\
\hline 1971 & 2774 & 216.3 & 1300 & 751 & 774 & 23 & 56.5 & 5889 \\
\hline 1972 & 2445 & 192.1 & 1310 & 752 & 775 & 23 & 56.9 & 5888 \\
\hline 1973 & 3256 & 257.8 & 1320 & 755 & 778 & 23 & 57.4 & 5885 \\
\hline 1974 & 3241 & 255.3 & 1313 & 756 & 779 & 23 & 57.1 & 5884 \\
\hline 1975 & 3421 & 269.3 & 1312 & 757 & 780 & 23 & 57.0 & 5883 \\
\hline 1976 & 3171 & 268.3 & 1410 & 758 & 784 & 26 & 54.2 & 5882 \\
\hline 1977 & 2792 & 235.5 & 1406 & 758 & 784 & 26 & 54.1 & 5882 \\
\hline 1978 & 2516 & 211.0 & 1398 & 759 & 784 & 25 & 55.9 & 5881 \\
\hline 1979 & 2359 & 197.2 & 1393 & 760 & 784 & 24 & 58.0 & 5880 \\
\hline 1980 & 2796 & 234.4 & 1397 & 760 & 785 & 25 & 55.9 & 5880 \\
\hline 1981 & 2784 & 232.4 & 1391 & 761 & 786 & 25 & 55.7 & 5879 \\
\hline 1982 & 2831 & 238.1 & 1402 & 762 & 785 & 23 & 61.0 & 5878 \\
\hline 1983 & 2496 & 207.6 & 1386 & 762 & 785 & 23 & 60.3 & 5878 \\
\hline 1984 & 3317 & 275.6 & 1385 & 762 & 787 & 25 & 55.4 & 5878 \\
\hline 1985 & 2643 & 221.2 & 1395 & 762 & 784 & 22 & 63.4 & 5878 \\
\hline 1986 & 2920 & 244.8 & 1397 & 763 & 787 & 24 & 58.2 & 5877 \\
\hline 1987 & 2984 & 250.2 & 1397 & 763 & 788 & 25 & 55.9 & 5877 \\
\hline 1988 & 2766 & 232.0 & 1397 & 764 & 788 & 24 & 58.2 & 5876 \\
\hline 1989 & 2656 & 221.0 & 1386 & 765 & 791 & 26 & 53.3 & 5875 \\
\hline 1990 & 2949 & 244.6 & 1382 & 767 & 790 & 23 & 60.1 & 5873 \\
\hline 1991 & 2752 & 229.5 & 1385 & 768 & 791 & 23 & 60.2 & 5872 \\
\hline 1992 & 3610 & 307.4 & 1419 & 770 & 794 & 24 & 59.1 & 5870 \\
\hline 1993 & 2018 & 168.5 & 1391 & 771 & 797 & 26 & 53.5 & 5869 \\
\hline 1994 & 966 & 78.8 & 1359 & 772 & 796 & 24 & 56.6 & 5868 \\
\hline 1995 & 1971 & 159.7 & 1350 & 772 & 796 & 24 & 56.3 & 5868 \\
\hline 1996 & 1401 & 118.5 & 1410 & 776 & 802 & 26 & 54.2 & 5864 \\
\hline 1997 & 961 & 80.6 & 1398 & 779 & 805 & 26 & 53.8 & 5861 \\
\hline 1998 & 2609 & 222.5 & 1395 & 780 & 808 & 27 & 51.5 & 5860 \\
\hline 1999 & 1607 & 135.0 & 1400 & - & - & - & - & - \\
\hline 2000 & 1107 & 93.0 & 1400 & - & - & - & - & - \\
\hline 2001 & 1093 & 91.8 & 1400 & - & - & - & - & - \\
\hline Total & 85,686 & 7059.8 & & & & & & \\
\hline Minimum & 961 & 79 & 1300 & 743 & 771 & 22 & 47.9 & 5860 \\
\hline Maximum & 3610 & 307 & 1419 & 780 & 808 & 28 & 63.4 & 5897 \\
\hline Average & 2520 & 208 & 1375 & 762 & 787 & 24 & 56.2 & 5878 \\
\hline
\end{tabular}

Note: Well completed Nov. 1966; initial depth to water: $740 \mathrm{ft}$; surface elevation 6,640 ft. 
Well PM-4

\begin{tabular}{|c|c|c|c|c|c|c|c|c|}
\hline Year & $\begin{array}{c}\text { Pump } \\
\text { Time (h) }\end{array}$ & $\begin{array}{c}\text { Production } \\
\text { (10 }{ }^{6} \text { gal.) }\end{array}$ & $\begin{array}{l}\text { Pump } \\
\text { Rate } \\
\text { (gpm) }\end{array}$ & $\begin{array}{c}\text { Average Wat } \\
\text { Nonpumping } \\
\text { (ft) }\end{array}$ & $\begin{array}{c}\text { ter Level } \\
\text { Pumping } \\
\text { (ft) }\end{array}$ & $\begin{array}{c}\text { Drawdown } \\
\text { (ft) }\end{array}$ & $\begin{array}{c}\text { Specific } \\
\text { Capacity } \\
\text { (gpm/ft) }\end{array}$ & $\begin{array}{l}\text { Nonpumping } \\
\text { Water } \\
\text { Elevation (ft) }\end{array}$ \\
\hline$\overline{1981}$ & & & & 1060 & & & & \\
\hline 1982 & 869 & 76.2 & 1460 & 1050 & 1091 & 41 & 35.6 & 5870 \\
\hline 1983 & 5267 & 452.5 & 1432 & 1066 & 1101 & 35 & 40.9 & 5854 \\
\hline 1984 & 4059 & 325.8 & 1338 & 1065 & 1104 & 39 & 34.3 & 5855 \\
\hline 1985 & 4759 & 379.2 & 1328 & 1066 & 1101 & 35 & 37.9 & 5854 \\
\hline 1986 & 3925 & 307.4 & 1305 & 1084 & 1119 & 35 & 37.3 & 5836 \\
\hline 1987 & 5071 & 392.2 & 1289 & 1081 & 1117 & 36 & 35.8 & 5839 \\
\hline 1988 & 2435 & 218.7 & 1313 & 1079 & 1117 & 38 & 34.6 & 5841 \\
\hline 1989 & 5387 & 418.9 & 1296 & 1085 & 1122 & 37 & 35.0 & 5835 \\
\hline 1990 & 2827 & 219.3 & 1293 & 1083 & 1123 & 40 & 32.3 & 5837 \\
\hline 1991 & 2832 & 219.5 & 1292 & 1081 & 1123 & 42 & 30.8 & 5839 \\
\hline 1992 & 2064 & 158.3 & 1278 & 1084 & 1125 & 41 & 31.2 & 5836 \\
\hline 1993 & 3901 & 249.7 & 1295 & - & - & - & - & - \\
\hline 1994 & 6178 & 463.5 & 1250 & 1085 & 1128 & 43 & 29.1 & 5835 \\
\hline 1995 & 5736 & 428.2 & 1244 & - & - & - & - & - \\
\hline 1996 & 2721 & 207.4 & 1270 & 1091 & 1139 & 48 & 26.5 & 5829 \\
\hline 1997 & 5222 & 414.5 & 1323 & 1093 & 1142 & 49 & 27.0 & 5827 \\
\hline 1998 & 996 & 74.9 & 1224 & 1092 & 1128 & 36 & 34.0 & 5828 \\
\hline 1999 & 1335 & 112.2 & 1400 & 1082 & 1133 & 52 & 27.2 & 5838 \\
\hline 2000 & 2416 & 192.8 & 1330 & 1082 & 1133 & 51 & 26.2 & 5838 \\
\hline 2001 & 2478 & 197.8 & 1330 & 1079 & 1131 & 53 & 25.2 & 5841 \\
\hline Total & 70,479 & 5509.0 & & & & & & \\
\hline Minimum & 869 & 74.9 & 1224 & 1050 & 1091 & 35 & 25.2 & 5827 \\
\hline Maximum & 6178 & 463.5 & 1460 & 1093 & 1142 & 53 & 40.9 & 5870 \\
\hline Average & 3524 & 275 & 1315 & 1079 & 1121 & 42 & 32.3 & 5841 \\
\hline
\end{tabular}

Note: Well completed Aug. 1981; initial depth to water: $1060 \mathrm{ft}$; surface elevation 6,920 ft. 
Well PM-5

\begin{tabular}{|c|c|c|c|c|c|c|c|c|}
\hline Year & $\begin{array}{l}\text { Pump } \\
\text { Time (h) }\end{array}$ & $\begin{array}{c}\text { Production } \\
\left(10^{6} \text { gal. }\right)\end{array}$ & $\begin{array}{l}\text { Pump } \\
\text { Rate } \\
\text { (gpm) }\end{array}$ & $\begin{array}{c}\text { Average Wat } \\
\text { Nonpumping } \\
\text { (ft) }\end{array}$ & $\begin{array}{c}\text { ter Level } \\
\text { Pumping } \\
\text { (ft) }\end{array}$ & $\begin{array}{c}\text { Drawdown } \\
\text { (ft) }\end{array}$ & $\begin{array}{l}\text { Specific } \\
\text { Capacity } \\
\text { (gpm/ft) }\end{array}$ & $\begin{array}{l}\text { Nonpumping } \\
\text { Water } \\
\text { Elevation (ft) }\end{array}$ \\
\hline 1982 & & & & 1208 & & & & \\
\hline 1983 & - & - & - & - & - & - & - & - \\
\hline 1984 & - & - & - & - & - & - & - & - \\
\hline 1985 & - & 2.0 & - & - & - & - & - & - \\
\hline 1986 & 2047 & 147.3 & 1,199 & - & - & - & - & - \\
\hline 1987 & 1620 & 118.6 & 1,220 & 1,237 & 1,345 & 108 & 11.3 & 5858 \\
\hline 1988 & 1754 & 128.6 & 1,221 & 1,233 & 1,345 & 112 & 10.9 & 5862 \\
\hline 1989 & 1184 & 86.2 & 1,213 & 1,239 & 1,352 & 113 & 10.7 & 5856 \\
\hline 1990 & 1611 & 121.0 & 1,252 & 1,234 & 1,347 & 113 & 11.1 & 5861 \\
\hline 1991 & 1497 & 112.1 & 1,248 & 1,239 & 1,346 & 107 & 11.7 & 5856 \\
\hline 1992 & 2823 & 208.4 & 1,233 & 1,248 & 1,345 & 97 & 12.7 & 5847 \\
\hline 1993 & 1709 & 126.0 & 1,229 & 1,224 & 1,321 & 97 & 12.7 & 5871 \\
\hline 1994 & 2131 & 156.9 & 1,227 & 1,234 & 1,314 & 80 & 15.3 & 5861 \\
\hline 1995 & 3948 & 291.0 & 1,228 & - & - & - & - & - \\
\hline 1996 & 2978 & 224.6 & 1,257 & 1,258 & 1,351 & 93 & 13.5 & 5837 \\
\hline 1997 & 1261 & 91.8 & 1,213 & 1,254 & 1,342 & 88 & 13.8 & 5841 \\
\hline 1998 & 3155 & 222.8 & 1,161 & 1236 & 1321 & 84 & 13.7 & 5859 \\
\hline 1999 & 3361 & 237.0 & 1,175 & - & - & - & - & - \\
\hline 2000 & 2628 & 185.3 & 1,175 & 1239 & 1320 & 81 & 14.5 & 5856 \\
\hline 2001 & 1786 & 125.9 & 1,175 & - & - & - & - & - \\
\hline Total & 35,493 & 2583.5 & & & & & & \\
\hline Minimum & 1184 & 2.0 & 1161 & 1224 & 1314 & 80 & 10.7 & 5837 \\
\hline Maximum & 3948 & 291.0 & 1257 & 1258 & 1352 & 113 & 15.3 & 5871 \\
\hline Average & 2218 & 152.1 & 1214 & 1240 & 1337 & 98 & 12.7 & 5855 \\
\hline
\end{tabular}

Note: Well completed Sept. 1982; initial depth to water: 1,208 ft; surface elevation 7,095 ft. 



\section{Appendix E}

Short-Term Water-Level Data 



\section{Appendix E. Short-Term Water-Level Data}

The short-term water-level trends of water supply wells typically show the water level responses to the varying pumping demands placed on each well. The time series plots of pumping and nonpumping shortterm water-level trends of active water supply wells are shown and discussed below for each active supply well. Each water level figure shows the monthly production from the well where water levels were obtained and for nearby wells that appear to indicate water level impacts. A summary of the short-term water-level data can be found in Section 3.1.

Water-level data for supply wells were obtained by LAC personnel using pressure transducers, except for wells G-1A, PM-1 and PM-3, which are equipped with bubble pressure lines. When pressure transducers are installed, water-level measurements are usually obtained manually to calibrate the transducer readings. Occasionally the pressure transducers fail and must be removed or replaced during well maintenance activities. When transducers are replaced, the measurement datum may change by up to 1 to $2 \mathrm{ft}$; as a result, some water-level records might indicate false.

Most water supply wells at Los Alamos are electric and are operated daily during nonpeak electrical demand times. Therefore, most wells are turned on and off each day, which does not allow sufficient time for static pumping or nonpumping water levels to be determined. Well PM-4 is usually operated continuously during summer peak demand periods and is usually not operated during winter months; thus, pumping and nonpumping water levels for this well may at times approach static conditions each year.

The pumping and nonpumping water-level data for the water supply wells were compiled for this report on approximately a weekly basis for each well and the average values for the year were determined (see Appendix D). Water levels in production wells are obtained by two methods: (1) some wells have chart recorders that continuously record water levels above the pump, whether the wells are pumping or not pumping, and (2) some wells have digital readouts in the well house that display the water level above the pump. For wells with digital readouts, Los Alamos County employees manually record the water level usually twice daily during routine inspections of the well equipment and note whether the pump was operating at the time the water level was recorded.

The pumping and nonpumping water levels of wells with chart recorders were determined by obtaining the highest water level when the well is not pumping and the lowest water level when the well is pumping for each week. For wells with digital readouts, the daily well inspection and water-level records were reviewed and the highest nonpumping water levels and the lowest pumping water levels were documented for each week. This approach attempts to obtain pumping and nonpumping water levels that approach static conditions and eliminates intermediate water levels obtained when the well was on or off for short periods of time. The weekly pumping and nonpumping water-level data were compiled for each well, and the data were entered into a database for data storage and retrieval.

\section{Guaje Field}

Figure E-1 shows the pumping and nonpumping water levels in well G-1A from 1997 through 2001, along with the monthly production history for the well. During 1997 and 1998, pumping and nonpumping water levels typically did not vary more than about $20 \mathrm{ft}$ in response to changes in pumping demand. 


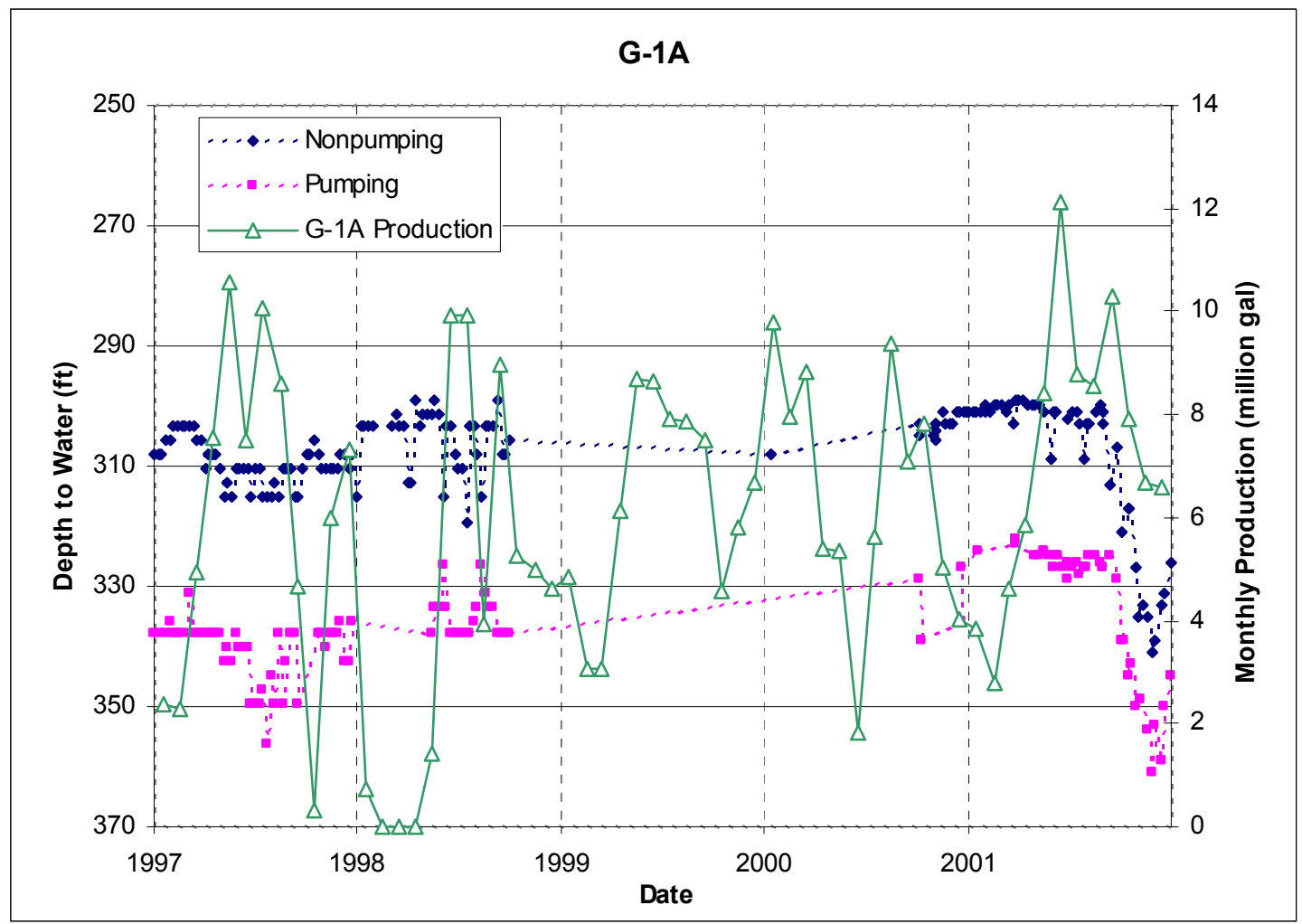

Figure E-1. Nonpumping and pumping water levels and monthly production, well G-1A, 1997 - 2001

During drilling of the Guaje replacement wells in late 1997 and early 1998, production from nearby wells was curtailed to allow water levels to recover in the Guaje field. Well G-1A was not pumped regularly during October 1997 and January through April 1998; during this time the nonpumping water level in well G-1A rose about $15 \mathrm{ft}$, from about $315 \mathrm{ft}$ below surface to about $300 \mathrm{ft}$ below surface. When the well was placed back in routine service in June 1998, the nonpumping water levels returned to an average of $310 \mathrm{ft}$ below surface. Nonpumping water levels during the winter of 2000 and 2001 again recovered to about $300 \mathrm{ft}$ below surface in response to seasonal lower water demand. During the last quarter of 2001, the pumping and nonpumping water levels in well G-1A declined about $100 \mathrm{ft}$. These water levels do not appear to correspond with the monthly production demand of the well or to nearby well G-2A (which exhibits a rising water level during this quarter); these water levels may represent a malfunction of the recording device in well G-1A.

The pumping and nonpumping water levels and monthly production for replacement well G-2A for 1998 through 2001 are shown in Figure E-2, along with monthly production from well G-2A and nearby well G-3A. The water levels shown for 1998 were obtained during the pumping tests performed upon completion of the well. The well was connected to distribution pipelines and placed in production in June 1999. Soon after production began from well G-2A, the nonpumping water level was about $400 \mathrm{ft}$ below surface, until May and June of 2000 when production demand was greatest (during and after the Cerro Grande fire). During this time, the nonpumping water level declined about $60 \mathrm{ft}$, to around $460 \mathrm{ft}$ below surface, in response to the higher production from G-2A and from nearby well G-3A. During the winter months of 2000-2001, well G-2A was not in routine service and the nonpumping water level recovered to about $350 \mathrm{ft}$ below surface, within about $30 \mathrm{ft}$ of the initial 1998 water level. In 2001, the nonpumping and pumping water levels responded to production in a similar manner; however, reduced production demands led to reduced declines in water levels. The lowest nonpumping water levels in well G-2A in 2001 resulted from pumping both wells G-2A and G-3A in June 2001 (Figure E-2). 


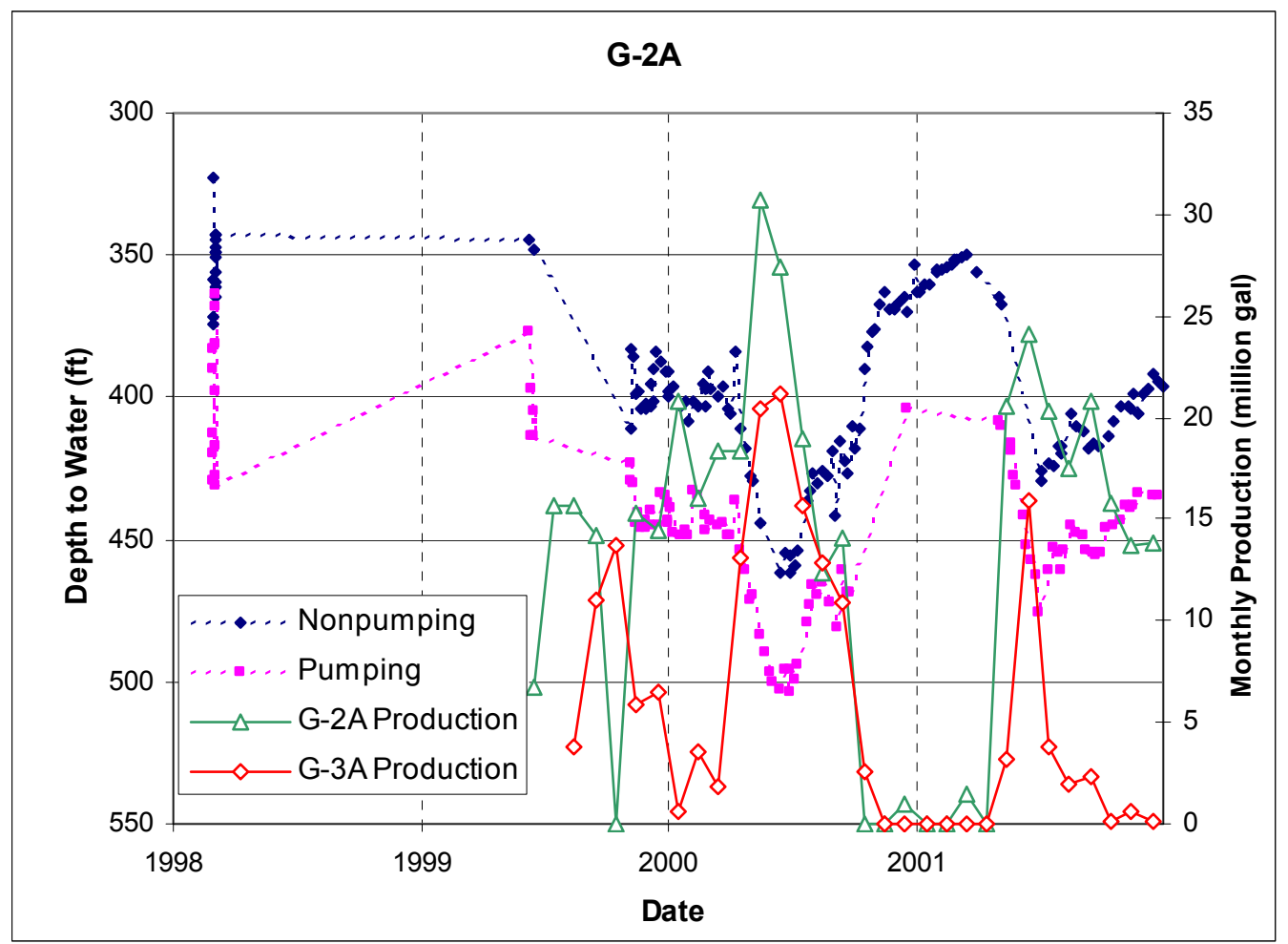

Figure E-2. Nonpumping and pumping water levels and monthly production, well G-2A, $1998-2001$

The pumping and nonpumping water levels and monthly production for well G-3A for 1998 through 2001 are shown in Figure E-3. The 1998 water levels illustrate the range in pumping and nonpumping water levels that occurred during the pumping tests when the well was completed. Well G-3A was placed into production in August 1999; the first available water levels in October indicate that nonpumping water levels were about $425 \mathrm{ft}$ below surface. During the low demand winter months of 1999-2000, the nonpumping water level recovered slightly to about $410 \mathrm{ft}$ below surface. During the summer of 2000, the nonpumping water levels in well G-3A fell to about $480 \mathrm{ft}$ below surface. Water-level data for well G-3A during the winter months of 2000-2001 indicate falling water levels when the well was not in production; these data suggest a problem with the recording device and are not reliable.

The pumping and nonpumping water levels and monthly production for well G-4A for 1998 through 2000 are shown in Figure E-4. The 1998 water levels illustrate the range in pumping and nonpumping water levels that occurred during the pumping tests when the well was completed. Well G-4A was placed into production in June 1999 when initial water levels were about $450 \mathrm{ft}$ below surface. Pumping during the summer of 1999 lowered nonpumping water levels to about $490 \mathrm{ft}$ below surface; during the winter of 1999-2000 the water level recovered to about $475 \mathrm{ft}$ below surface. Pumping during the summer of 2000 lowered nonpumping water levels to about $510 \mathrm{ft}$ below surface. Well G-4A was not in routine production through most of 2001 , and water level data were not routinely obtained. 


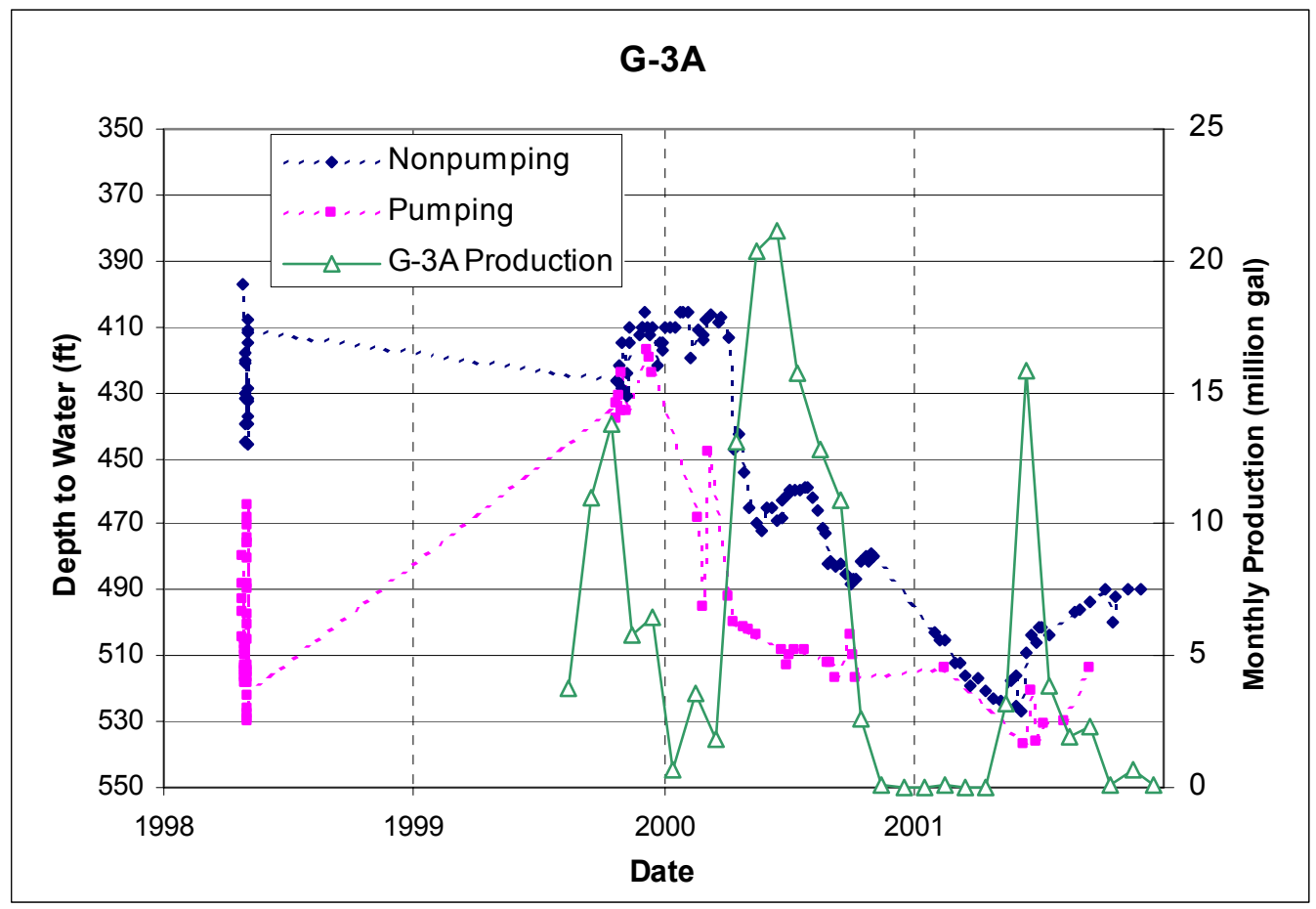

Figure E-3. Nonpumping and pumping water levels and monthly production, well G-3A, $1998-2001$

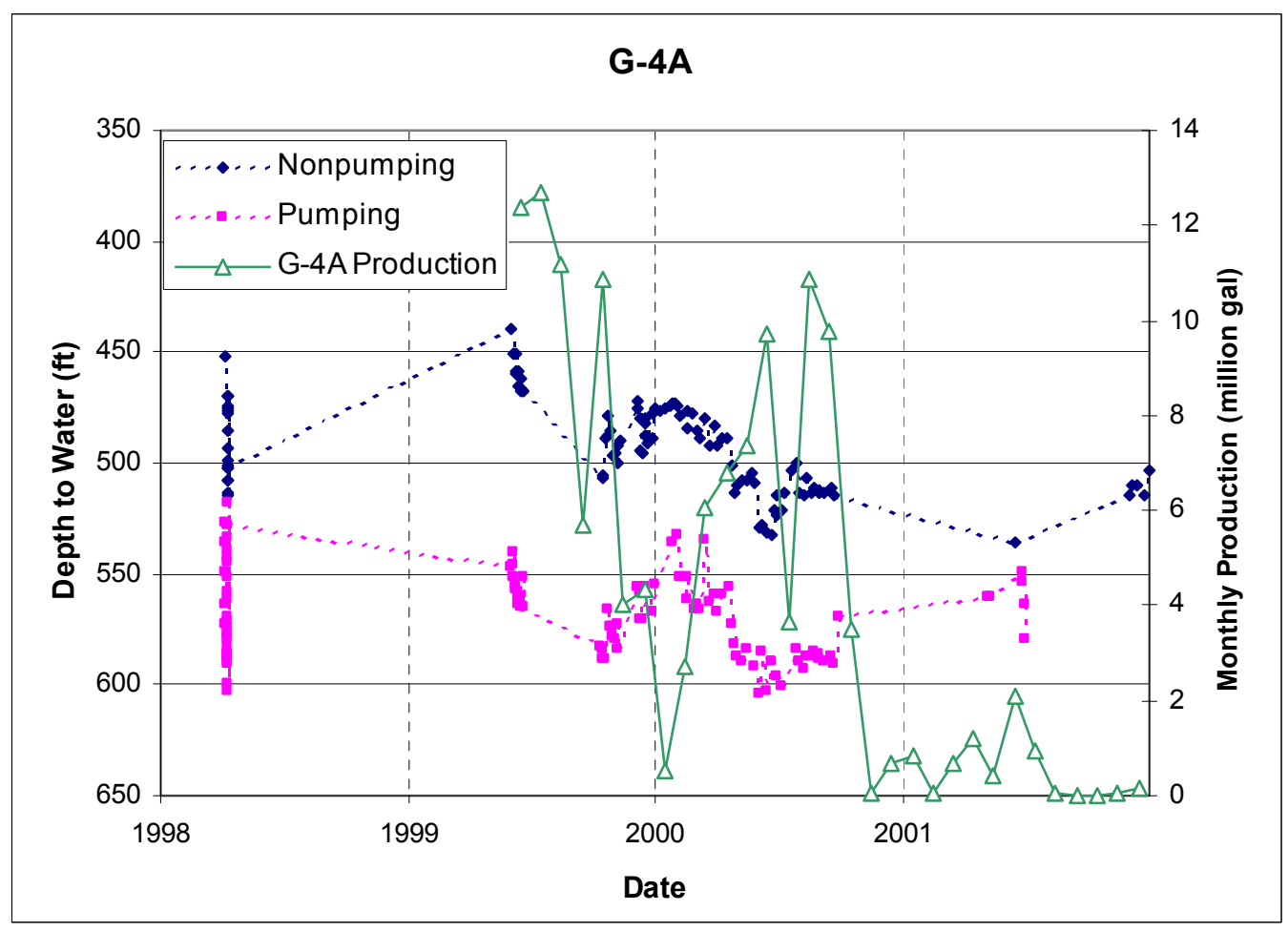

Figure E-4. Nonpumping and pumping water levels and monthly production, well G-4A, $1998-2001$ 
The pumping and nonpumping water levels and monthly production for well G-5A for 1998 through 2001 are shown in Figure E-5. The 1998 water levels illustrate the range in pumping and nonpumping water levels that occurred during the pumping tests when the well was completed. Well G-5A was placed into production in September 1999, but few water levels are available because this well has not been in routine production. The nonpumping water levels in 2000 were about $560 \mathrm{ft}$ below surface and in the latter part of 2001 were about $575 \mathrm{ft}$ below surface.

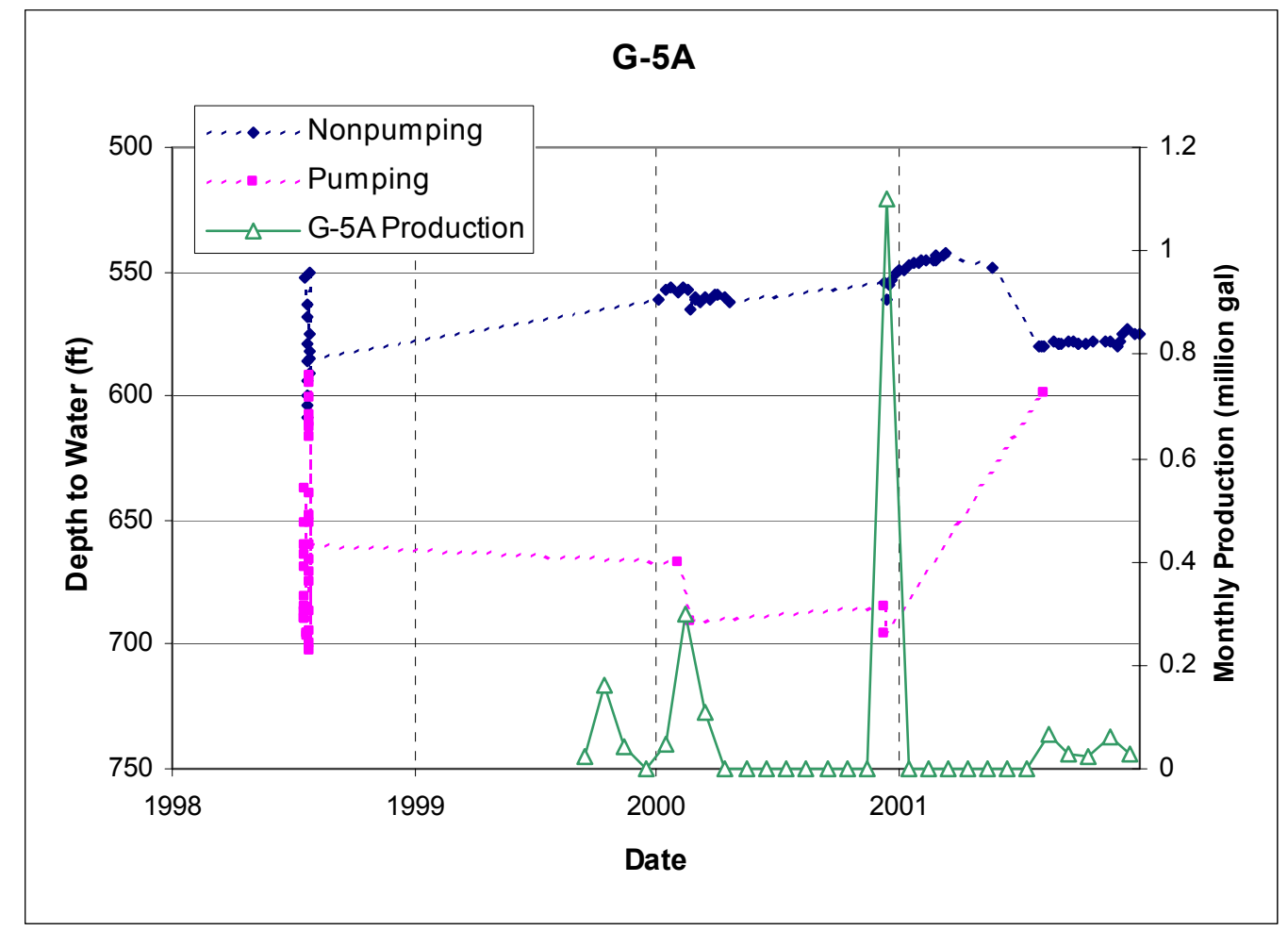

Figure E-5. Nonpumping and pumping water levels and monthly production, well G-5A, $1998-2001$ 


\section{Pajarito Field}

The available pumping and nonpumping water levels and monthly production for well PM-1 for 1998 through 2001 are shown in Figure E-6. Water levels for well PM-1 are only available for 1998, when the nonpumping water levels ranged from 753 to $768 \mathrm{ft}$ below surface in response to pumping demands.

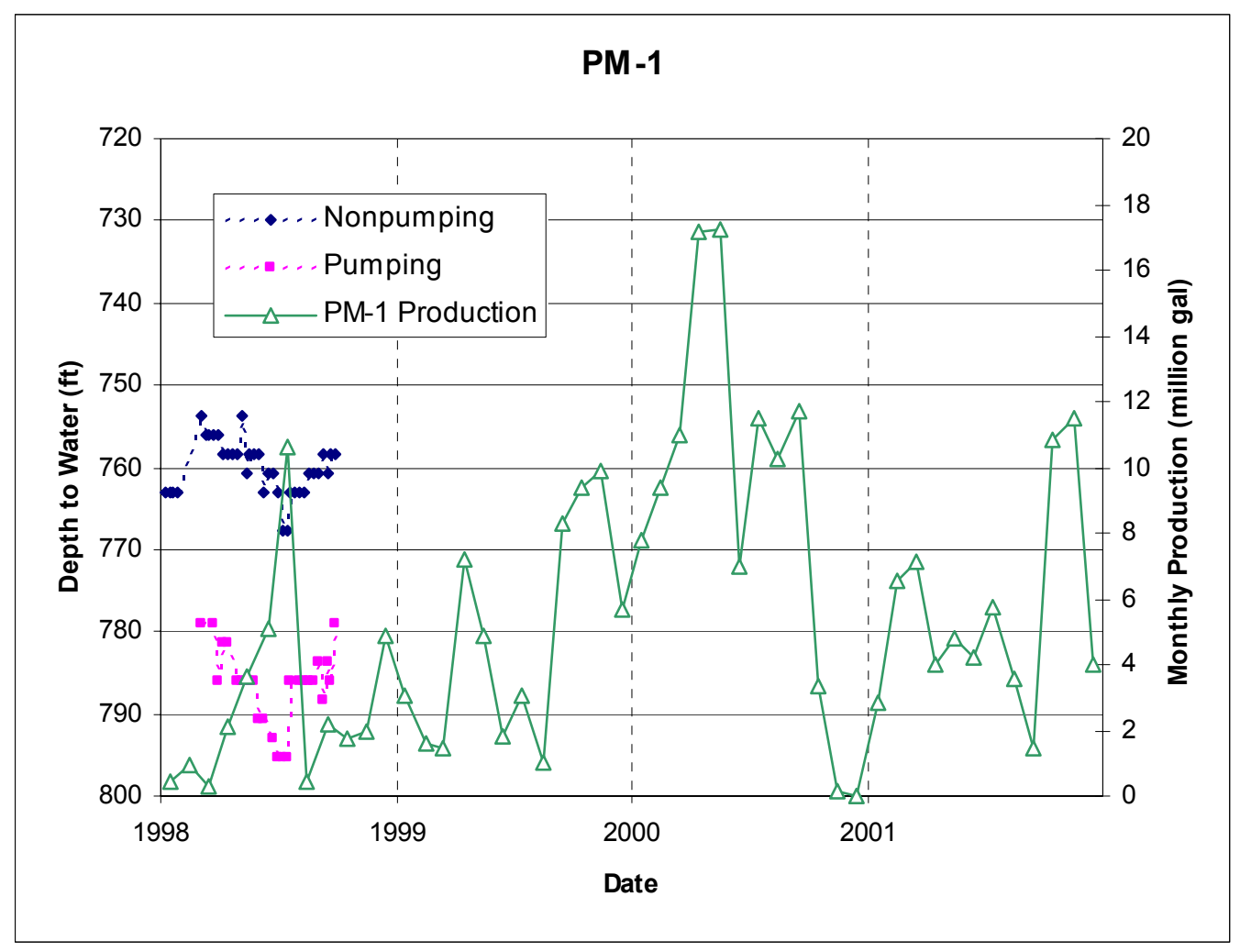

Figure E-6. Nonpumping and pumping water levels and monthly production, well PM-1, 1998- 2001

The pumping and nonpumping water levels and monthly production for well PM-2 for 1998 through 2001 are shown in Figure E-7. Well PM-2 is usually pumped routinely so short-term nonpumping water levels show fluctuations depending on the amount of recovery time between pumping. Nonpumping water levels in well PM-2 in 1998 were about 830 to $850 \mathrm{ft}$ below surface, and in 2000 about 840 to $860 \mathrm{ft}$ below surface. In 2001, water levels ranged from 840 to $870 \mathrm{ft}$ below surface. The water levels in well PM-2 respond to the pumping demand and during the winter months of 2000-2001, recovered about $20 \mathrm{ft}$ in response to reduced production.

The monthly production from nearby well PM-4 is also shown on Figure E-7. The pumping and nonpumping water levels at well PM-2 show the impact of high volume pumping at PM-4. The lowest pumping and nonpumping water levels observed at well PM-2 in the summer of 2000 and 2001 occurred when nearby well PM-4 was operating at peak production. 


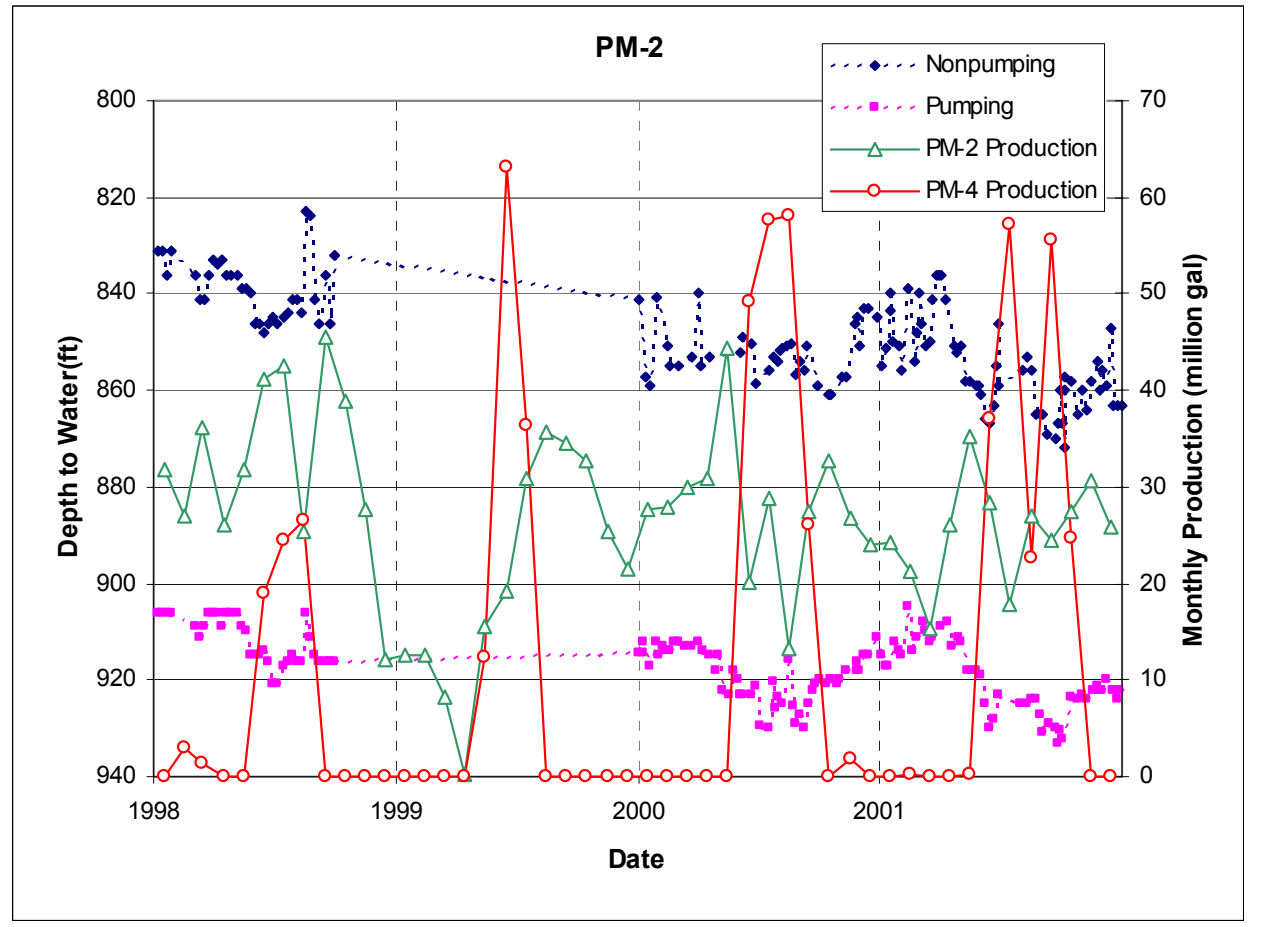

Figure E-7. Nonpumping and pumping water levels and monthly production, well PM-2, 1998-2001

The available pumping and nonpumping water levels and monthly production for well PM-3 for 1998 through 2001 are shown in Figure E-8. Water levels for PM-3 are only available for part of 1998, when the nonpumping water level was relatively stable at about $780 \mathrm{ft}$ below surface. The nonpumping water level in well PM-3 varied only about $5 \mathrm{ft}$ in response to pumping demand in 1998.

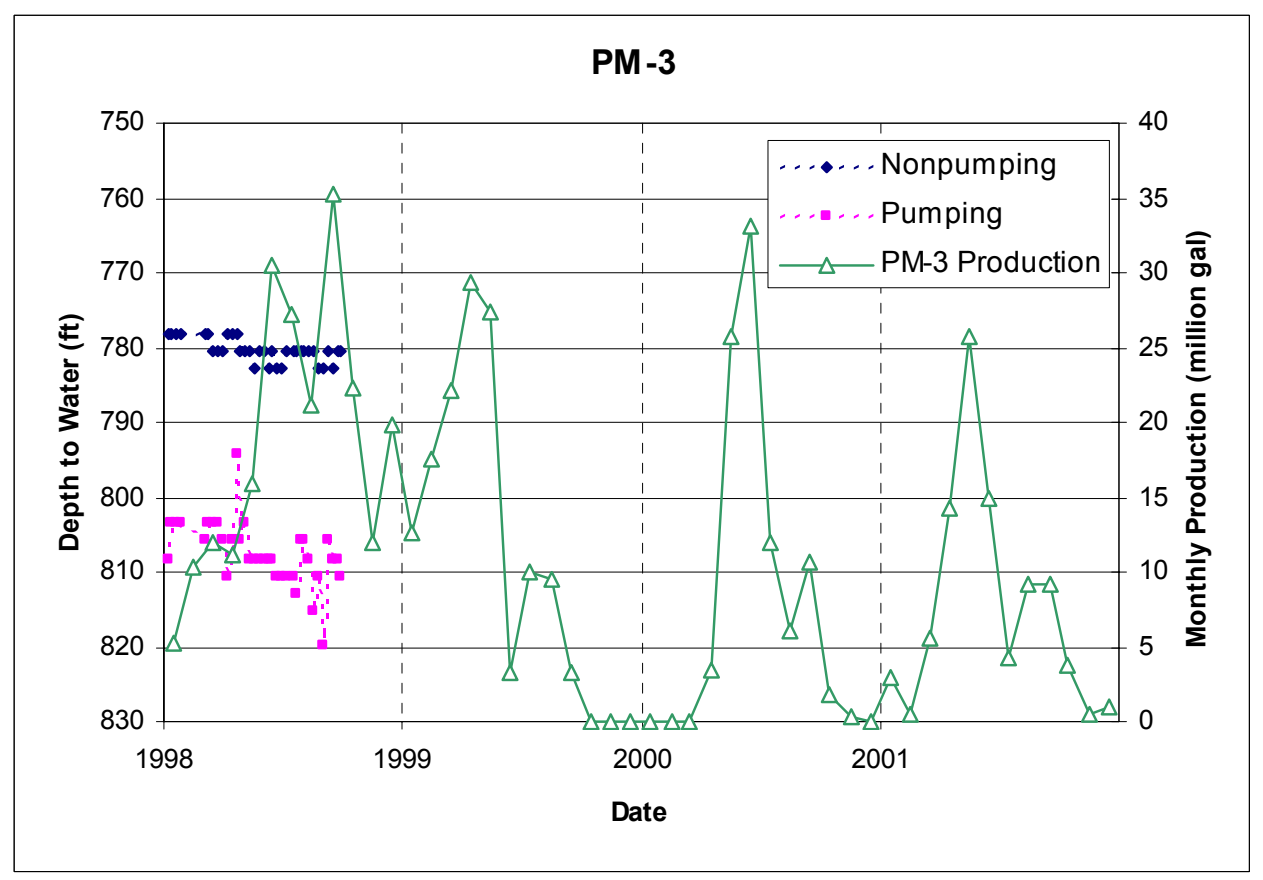

Figure E-8. Nonpumping and pumping water levels and monthly production, well PM-3, $1998-2001$ 
The available pumping and nonpumping water levels and monthly production for well PM-4 for 1998 through 2001 are shown in Figure E-9. Only this well produces continually when put into service each summer; thus, nonpumping water levels are obtained when the well is shut down for the winter season or when the well is temporarily shut down for service. In 1998, the nonpumping water levels after production were around $1095 \mathrm{ft}$ below surface, but in the spring of 1999 the water level had recovered about $20 \mathrm{ft}$ to about $1075 \mathrm{ft}$ below surface.

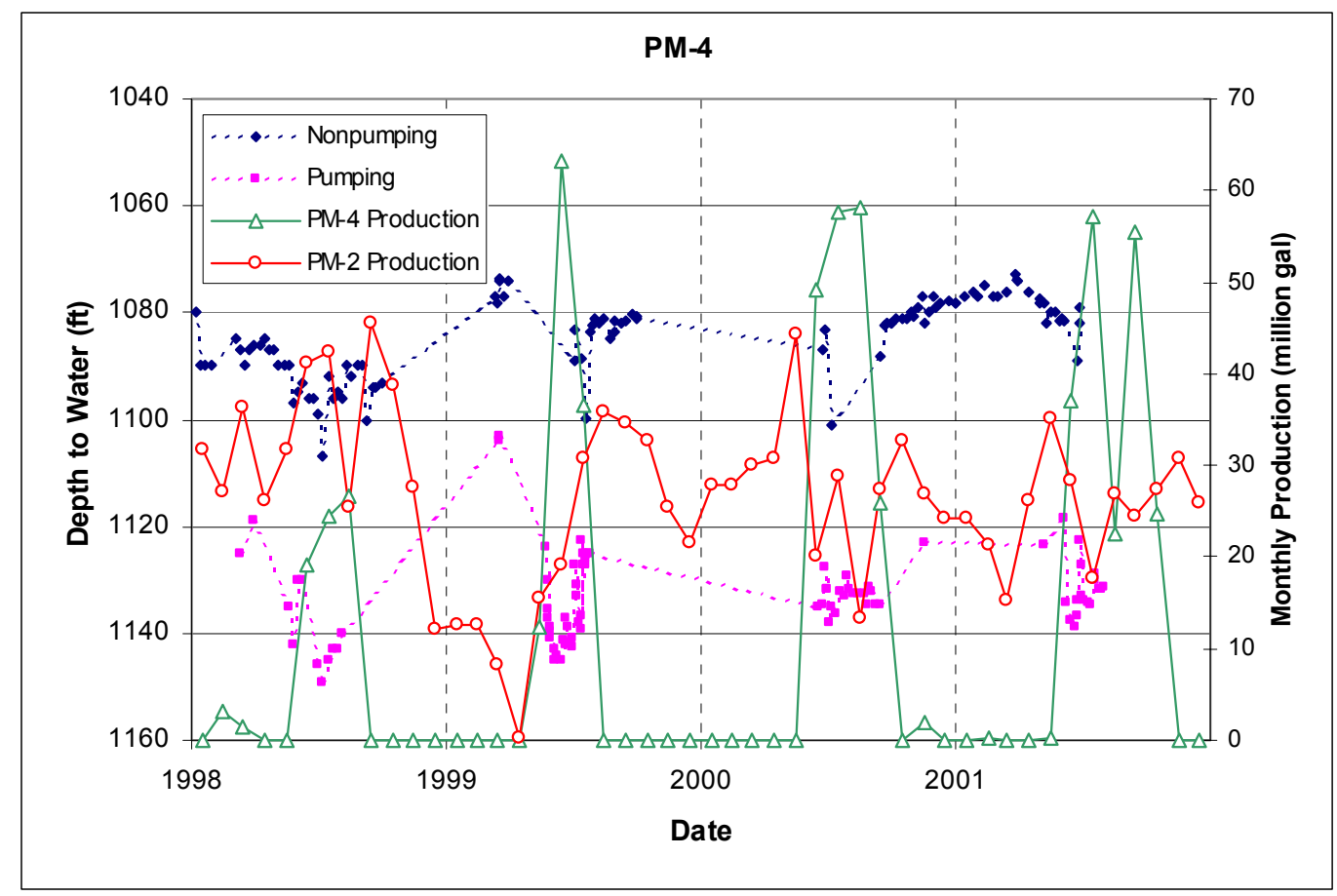

Figure E-9. Nonpumping and pumping water levels and monthly production, well PM-4, $1998-2001$

During the winter of 1998-1999, the pump in PM-4 was removed and replaced. In March 1999, before the pump was replaced, a spinner log survey was obtained while pumping the well at $1000 \mathrm{gpm}$ (Koch et al. 1999). The pumping and nonpumping water levels in March 1999 reflect the water levels observed before and during the spinner log survey.

The nonpumping water level after production in 2000 was about $1082 \mathrm{ft}$ below surface, after which the water level recovered slowly over the winter months to about $1075 \mathrm{ft}$ below surface in March 2001, similar to the level observed in March 1999. The nonpumping water level in well PM-4 began to decline in April 2001 in response to increased production from nearby well PM-2. The monthly production from well PM-2 is also shown in Figure E-9. Increased production at well PM-2 in April and May 2001, before well PM-4 was placed in service, caused a decline in the nonpumping water level in PM-4 of about $6 \mathrm{ft}$, from 1075 to $1081 \mathrm{ft}$. The transducer in well PM-4 malfunctioned in August 2001, so water levels after that date are not available.

The pumping and nonpumping water levels and monthly production for well PM-5 for 1998 through 2001 are shown in Figure E-10. Water-level data are available for 1998 and part of 2000. The transducer malfunctioned in September 2000; thus, water levels are not available after that date. The water levels in PM-5 respond within a range of about 10 to $15 \mathrm{ft}$ to production demands on the well. The monthly production from nearby well PM-4 is also shown on Figure E-10. During the summer of 2000, a decline in pumping water levels in well PM-5 may have resulted from production from PM-4. 


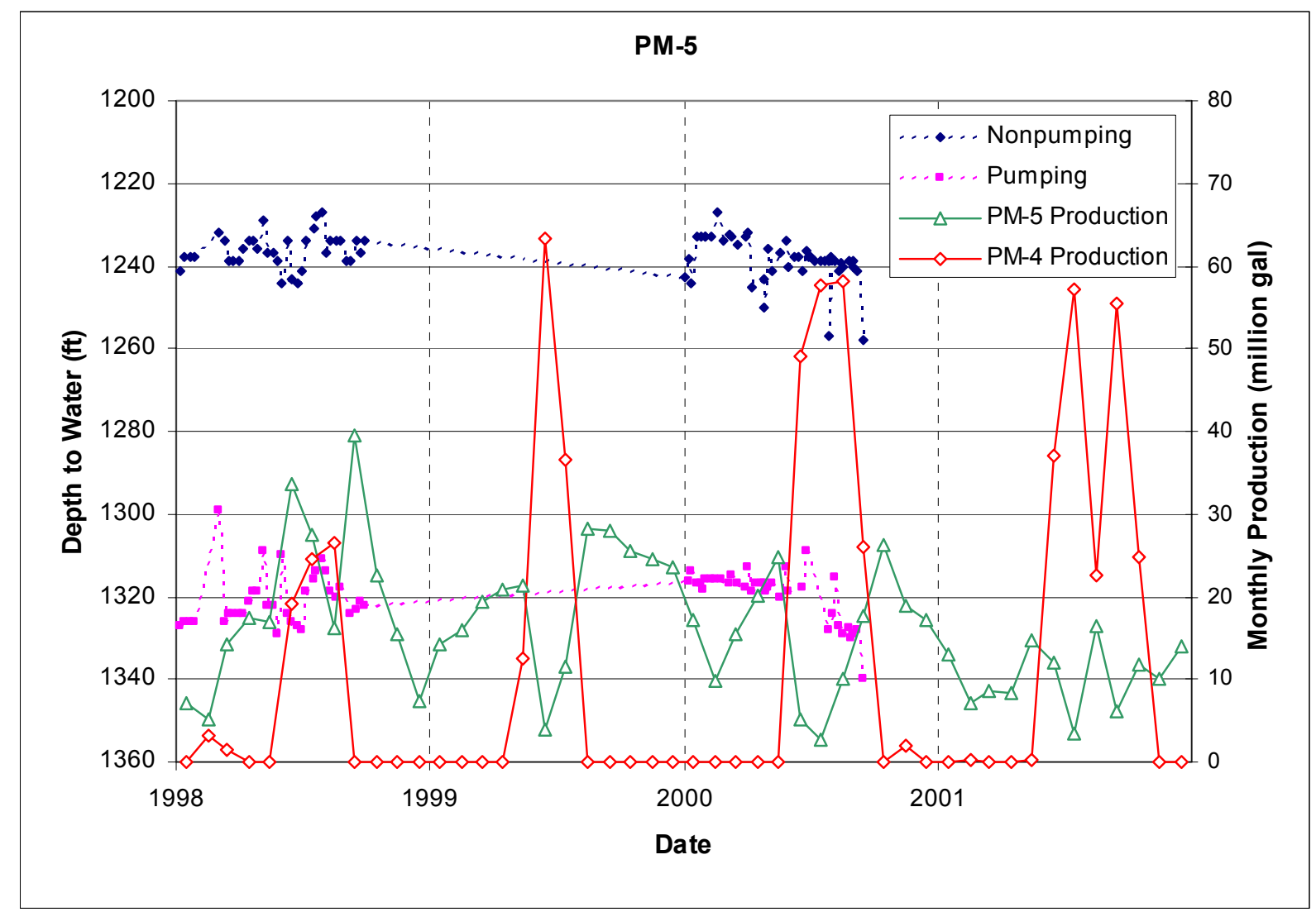

Figure E-10. Nonpumping and pumping water levels and monthly production, well PM-5, $1998-2001$ 



\section{Appendix F}

Static Water Levels in Regional Aquifer Test Wells 



\section{Appendix F. Static Water Levels in Regional Aquifer Test Wells}

Table F-1

Depth to Water Measurements in Regional Aquifer Test Wells

\begin{tabular}{|c|c|c|c|c|c|c|c|c|}
\hline $\begin{array}{l}\text { Date Drilled } \\
\text { Datum (ft) } \\
\text { Initial WL (ft) }\end{array}$ & $\begin{array}{c}1950 \\
6369.2 \\
584.9\end{array}$ & $\begin{array}{c}1949 \\
6647.6 \\
758.9\end{array}$ & $\begin{array}{c}1949 \\
6595.3 \\
743.3\end{array}$ & $\begin{array}{c}1950 \\
7244.6 \\
1170.8\end{array}$ & $\begin{array}{c}1960 \\
6877.6 \\
968.0\end{array}$ & $\begin{array}{c}1959 \\
7143.9 \\
1173.2\end{array}$ & $\begin{array}{c}1960 \\
6936.7 \\
1003.3\end{array}$ & $\begin{array}{c}1960 \\
7019.9 \\
1090.6\end{array}$ \\
\hline Year & TW-1 & TW-2 & TW-3 & TW-4 & TW-8 & DT-5A & DT-9 & DT-10 \\
\hline 1949 & & 758.9 & 743.3 & & & & & \\
\hline 1950 & 584.9 & & & 1170.8 & & & & \\
\hline 1951 & 592.3 & 760.1 & 750.9 & 1166.1 & & & & \\
\hline 1952 & 591.4 & & 751.0 & 1166.6 & & & & \\
\hline 1953 & 591.2 & 759.9 & 751.4 & 1167.5 & & & & \\
\hline 1954 & 591.8 & 760.6 & 751.4 & 1166.2 & & & & \\
\hline 1955 & & 760.2 & 751.3 & & & & & \\
\hline 1956 & 592.0 & 759.9 & 750.9 & & & & & \\
\hline 1957 & 593.1 & 759.9 & 751.3 & & & & & \\
\hline 1958 & 593.8 & 759.7 & 751.7 & & & & & \\
\hline 1959 & 593.9 & & 751.8 & & & & & \\
\hline 1960 & 593.4 & 760.5 & 751.8 & 1165.9 & 968.0 & 1173.2 & 1003.3 & 1090.6 \\
\hline 1961 & 591.8 & 760.8 & & 1165.9 & & & 1003.4 & 1090.6 \\
\hline 1962 & 590.0 & 761.2 & 751.8 & & & & 1004.0 & \\
\hline 1963 & 588.3 & 762.8 & 753.6 & & 968.7 & 1176.9 & 1004.6 & 1090.3 \\
\hline 1964 & 587.8 & & 754.2 & & 968.7 & 1177.0 & 1005.0 & 1090.4 \\
\hline 1965 & 588.4 & & & & 968.7 & & 1005.1 & 1090.5 \\
\hline 1966 & & & & & & & 1005.2 & 1090.6 \\
\hline 1967 & & & & & & & 1005.4 & 1090.6 \\
\hline 1968 & & & & & & & 1005.5 & \\
\hline 1969 & & & & & & & & \\
\hline 1970 & & & & & & & & \\
\hline 1971 & & & & & & & 1005.5 & \\
\hline 1972 & & & & & & & 1005.2 & \\
\hline 1973 & & & & & & & 1005.3 & \\
\hline 1974 & & & & & & & 1005.6 & \\
\hline 1975 & & & & & & & 1005.6 & \\
\hline 1976 & & & & & & & 1005.8 & \\
\hline 1977 & & 775.5 & & & & & 1006.1 & \\
\hline 1978 & & & & & & & 1006.2 & \\
\hline 1979 & & & & & & & 1006.4 & \\
\hline 1980 & & & & & & & 1006.2 & \\
\hline 1981 & & & & & & & 1006.2 & \\
\hline 1982 & & & & & & & 1006.2 & \\
\hline 1983 & & & & & & & & \\
\hline 1984 & & & & & & & & \\
\hline 1985 & & & & & & & & \\
\hline 1986 & & & & & & & & \\
\hline 1987 & & & & & & & & \\
\hline 1988 & & 787.0 & & & & & & \\
\hline 1989 & & & & & & & & \\
\hline 1990 & 508.4 & 787.2 & 772.0 & & & & & \\
\hline 1991 & 507.0 & 789.0 & & & & & & \\
\hline 1992 & 536.5 & 792.5 & 777.5 & & & & & \\
\hline 1993 & 545.8 & 794.2 & 778.2 & 1176.3 & 993.3 & 1183.4 & 1016.0 & 1096.9 \\
\hline 1994 & 548.7 & 798.3 & 780.8 & 1176.9 & 993.1 & 1183.7 & 1016.3 & 1097.2 \\
\hline 1995 & 550.2 & 795.8 & 781.8 & 1177.2 & 994.4 & 1183.5 & 1015.5 & 1097.0 \\
\hline 1996 & 551.9 & 796.8 & 781.7 & 1176.4 & 994.7 & 1183.6 & 1015.8 & 1097.1 \\
\hline 1997 & 528.8 & & 782.2 & 1172.4 & 994.4 & & 1016.0 & 1097.3 \\
\hline
\end{tabular}

Note: Measurements are in feet below surface elevation datum. 
This report has been reproduced directly from the best available copy. It is available electronically on the Web at http://www.doe.gov/bridge.

Copies are available for sale to U.S. Department of Energy employees and contractors from

Office of Scientific and Technical Information

P.O. Box 62

Oak Ridge, TN 37831

(865) 576-8401

Copies are available for sale to the public from

National Technical Information Service

U.S. Department of Commerce

5285 Port Royal Road

Springfield, VA 22616

(800) 553-6847 


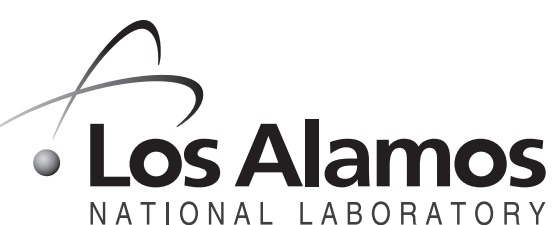

Los Alamos NM 87545 